\title{
Social networks and the resilience of rural communities in the Global South: a critical review and conceptual reflections
}

\author{
Till Rockenbauch $^{1}$ and Patrick Sakdapolrak ${ }^{2}$
}

\begin{abstract}
In the last decades, a growing scholarship has outlined the crucial role of social networks as a source of resilience. However, with regard to the Global South, the role of social networks for the resilience of rural communities remains an underresearched and underconceptualized issue, because research remains scattered between different strands and has rarely been integrated from a resilience perspective. To provide common ground for the exchange between disciplines and to identify steps towards a more comprehensive social network perspective on the resilience of rural communities in the Global South, we present a systematic review of contemporary case studies from three strands of research: (i) natural resource management, (ii) agricultural innovation, and (iii) social support. Although studies in each strand have their own particular strengths and weaknesses in addressing aspects of the resilience of rural communities in the Global South, they all share a static view of the outcomes of social networks, tend to emphasize structure over agency, and neglect spatial dimensions of social relations. To address these challenges, we propose a translocal social network perspective on resilience that views rural communities as being embedded in social networks that connect people and facilitate the flow of resources, information, and knowledge between places.
\end{abstract}

Key Words: Global South; migration; resilience; rural communities; social networks; translocality

\section{INTRODUCTION}

Rural communities can be understood as vulnerable socialecological systems (SES) that need to build resilience to withstand internal and external stresses from social, economic, and political changes (Adger 2000, Wilson et al. 2013). It has been argued that many aspects of adaptive capacity reside in social networks (Adger 2003) and that these are a crucial source of resilience (Folke et al. 2005, Folke 2006, Berkes and Ross 2013). This applies in particular to rural communities in the Global South, where often a lack of access to resources, knowledge, and functioning institutions is a major obstacle to sustainable development (Etzold et al. 2012). However, although investigations into the role of social networks is growing at a fast pace, it remains scattered across different strands of research, with related but separate research agendas (Videras 2013). With this paper, we provide a systematic review of current case studies from three of these strands, addressing different aspects relevant to the resilience of rural communities. By analyzing how case studies conducted between 2000 and 2015 conceptualize and operationalize social networks, we level the ground for the exchange between disciplines. Concluding we identify prospects for more fruitfully employing a social network perspective in investigating the resilience of rural communities in the Global South.

During the last decades, resilience has emerged as a key concept across disciplines for investigating responses to changes in human and ecological systems (Folke et al. 2010), resulting in a variety of ways in which resilience is understood, investigated, and applied (Downes et al. 2013). From a concept originally concerned with the persistence of ecological systems in the context of external disturbances (Holling 1973), resilience has developed through a concept underlining the role of adaptive capacity for navigating coupled SES (Gunderson and Holling 2002, Berkes et al. 2003) to one emphasizing the transformation of SES in the face of global change (Walker et al. 2004, Folke 2006, Folke et al.
2010). Attention has thus widened from the ecological to include also the social dimensions of resilience (Adger 2000, Cote and Nightingale 2012). This comprises, for example, human agency, social learning, and the skills and capacities of social actors to cope with, adapt to change, and facilitate transformation (Folke et al. 2010, Moore and Westley 2011, Berkes and Ross 2013, Keck and Sakdapolrak 2013, Skerratt 2013, Cretney 2014, Ifejika Speranza et al. 2014).

Similar to resilience, the concept of social networks has been applied in a wide range of sciences from the social to the physical (Borgatti et al. 2009, Scott 2011). Intermediating between micro and macro levels, the investigation of social networks is expected to provide answers to central challenges pertinent in sustainability science, such as promoting social learning, linking knowledge with action, and enhancing collective action (Henry and Vollan 2014). Social networks have been shown to foster the capacity to buffer, adapt to, and shape change (Moore and Westley 2011) by providing resources needed to cope with external stresses and disturbances (Adger 2003), and fostering humans' ability to initiate social innovations and act collectively (Folke et al. 2005, Newman and Dale 2005, More and Westley 2011). Against this background, resilience scholars are increasingly embracing the study of social networks as a promising way to operationalize social-ecological systems research (Janssen et al. 2006, Bodin et al. 2011, 2014, Bodin and Tengö 2012).

In general, a social network perspective refuses individualistic explanation of human behavior and places emphasis on the study of the relations between individuals and the structure of these relationships (Emirbayer and Goodwin 1994, Wassermann and Faust 1994, Fuhse and Mützel 2010). However, there is no uniform theoretical explanation as to why and how the structure of social relations matters (Borgatti et al. 2009, Fuhse and Mützel 2010), which has resulted in various conceptualizations and operational approaches toward social network research. 
Probably the most common and intuitive conception of social networks is as "pipes" (Podolny 2001), connecting various actors through flows of resources, information, or knowledge (Borgatti et al. 2009). Another popular conception is that of networks as "social capital" (Bourdieu 1986, Coleman 1988, Portes 1998, Putnam 2000, Woolcock and Narayan 2000). In essence, the concept of social capital addresses the value of social connectedness (Borgatti and Foster 2003) in terms of competitive advantages (Burt 2000) derived from resources embedded in social structure (Lin 1999). Finally, the conception of networks as a "form of coordination," as opposed to other principles of coordination such as market or hierarchy (Powell 1990), emphasizes the deliberative character of social networks and their potential to facilitate collective action, self-organization, and cross-scale coordination (Schneider et al. 2003, Olsson et al. 2004, Folke et al. 2005, Carlsson and Sandström 2008, Newig et al. 2010).

With regard to the operationalization, three approaches to social networks can be distinguished: metaphorical, descriptive, and structurally explicit (Bodin et al. 2011). In general, studies following metaphorical approaches treat networks as binary variables, which either do or do not exist, whereas studies following descriptive approaches distinguish key properties of networks, such as size, density, or strength of ties. In contrast, studies following structurally explicit approaches draw on formally defined methods of social network analysis (SNA) to analyze structural patterns of social relations derived from relational data.

Although recent years have witnessed major advances in employing a social network perspective in research on SES in general (Bodin and Prell 2011), the role of social networks for the resilience of rural communities is still under-researched and underconceptualized. An increasing number of studies are applying a social network perspective in addressing diverse issues such as, for example, the diffusion of sustainable agricultural practices (Conley and Udry 2001, Bandiera and Rasul 2006, Isaac 2012), the exchange of financial and material support in times of need (Cassidy and Barnes 2012, Scheffran et al. 2012, Islam and Walkerden 2014), and collective action regarding the sustainable management of natural resources (Tompkins et al. 2002, Crona and Bodin 2006, Ramirez-Sanchez and Pinkerton 2009). However, findings from these studies have rarely been integrated from a resilience perspective because contrasting conceptualizations and operationalization of social networks are hindering the exchange between disciplines. Moreover, a systematic synthesis of current research on social networks in rural communities in the Global South is lacking, as are conceptual reflections about implications for future research on the resilience of rural communities.

To close this gap, we present a systematic review of case studies from three different strands of research: (i) natural resource governance, (ii) agricultural innovation, and (iii) social support. Although studies in these strands do not necessarily refer to the concept of resilience in explicit and theoretically founded ways, we opt for a review of studies from these strands because they provide examples of how a social network perspective can be applied in addressing different aspects relevant to the resilience of rural communities in the Global South. For example, research on governance networks provides insights into how social networks facilitate collective action of stakeholders and the navigation and transformation of management systems; research on agricultural innovation networks reveals how social networks facilitate learning between farmers about improved agricultural crops and practices and therefore foster purposeful adaptation to changing conditions; and research on social support networks addresses the role of social networks as a means for households and communities to cope with changes by providing access to resources in times of need.

Although investigating related things, research in each strand is rooted in a different disciplinary background and hence tends to look at social networks from a different perspective. For example, research in the strand of natural resource governance is influenced by environmental management and SES research and hence focuses on social networks as a means of improving collaboration between stakeholders; research in agricultural innovation is informed by agricultural and development economics and hence perceives networks as a means of improving knowledge diffusion and social learning between farmers; and research on social support networks is shaped by vulnerability and disaster risk research and hence is primarily concerned with networks as a livelihood strategy of households and communities. Accordingly, studies from each strand tend to conceptualize and operationalize social networks differently.

By systematically analyzing how studies across these three strands conceptualize and operationalize social networks, this review aims at critically discussing the viability of current social network research and intends to reflect conceptual implications for future research. In the following sections, we outline the analytical framework and present the findings of our review. Based on this, we discuss strengths and weaknesses of each strand in addressing different aspects of resilience. Finally, we conclude by proposing a translocal social network perspective as a conceptual framework for future research on social networks and the resilience of rural communities in the Global South.

\section{METHODS}

To allow scientific studies with different research designs to be compared, we performed a systematic literature review (Petticrew and Roberts 2006). We applied a stepwise research procedure, starting with a search of ISI Web of Knowledge and Science Direct using the terms "social network," "resilience," and "rural community." Based on this preliminary sample, we included key terms related to the three strands of literature we aimed to address, such as "natural resource governance," "agricultural innovation," and "social support." To ensure comprehensibility, we decided on an additional open research approach including, inter alia, case studies that were frequently cited by previously identified sample studies. We restricted the research to peer-reviewed articles published in English between 2000 and 2015 and excluded all nonempirical articles and articles not related to the domain of rural development and only selected case studies from the Global South, based on the categories "low-income countries" and "middle-income countries" (World Bank 2016). We analyzed the final sample derived from this research procedure according to how studies (a) conceptualize and (b) operationalize social networks. Besides this, we (c) summarized for each strand key findings that related to aspects of the resilience of rural communities in the Global South. 
Table 1. Categories applied for the literature review.

\begin{tabular}{|c|c|c|}
\hline & Category applied: & Questions addressed: \\
\hline a) Conceptualization & a.(1) Conceptual framing & $\begin{array}{l}\text { Is resilience addressed explicitly or implicitly? } \\
\text { How are social networks and resilience framed? }\end{array}$ \\
\hline & $\begin{array}{l}\text { a.(2) Network variable } \\
\text { a.(3) Network narrative }\end{array}$ & $\begin{array}{l}\text { Are social networks treated as dependent or independent variables? } \\
\text { What is the underlying conception of social networks? }\end{array}$ \\
\hline b) Operationalization & $\begin{array}{l}\text { b.(1) Network approach } \\
\text { b.(2) Network definition }\end{array}$ & $\begin{array}{l}\text { What operational approach does the study follow? } \\
\text { What are the social relations of interest? } \\
\text { Who are the actors and what are the relevant scales of interaction? }\end{array}$ \\
\hline & b.(3) Network analysis & $\begin{array}{l}\text { On what network level does the analysis focus? } \\
\text { What network characteristics are addressed? }\end{array}$ \\
\hline c) Key findings & & $\begin{array}{l}\text { What key findings can be summarized regarding the question of how } \\
\text { social networks relate to aspects relevant to the resilience of rural } \\
\text { communities? }\end{array}$ \\
\hline
\end{tabular}

To analyze how social network research is conceptualized (a), we applied the following categories (see Table1):

a.(1) Conceptual framing: With this category, we indicate whether studies address resilience implicitly or explicitly, and how they frame social networks and resilience.

a.(2) Network variable: This category indicates whether studies treat social networks as an independent or dependent variable. Studies treating networks as an independent variable focus on how the structure of social relations impacts social behavior. If the focus is on why people are linked in a particular way, networks are treated as a dependent variable (Bodin and Crona 2009, Henning et al. 2012).

a.(3) Network narrative: We choose this category to address underlying theoretical assumptions about how networks make a difference. This includes the conception of social networks as "pipes" (Podolny 2001), as "social capital" (Bourdieu 1986, Coleman 1988, Putnam 2000), and as a "form of coordination" (Powell 1990).

To analyze how social network research is operationalized (b), we applied the following categories:

b.(1) Network approach: In line with Bodin et al., we distinguished between metaphorical approaches, descriptive approaches, and structurally explicit approaches (Bodin et al. 2011).

b.(2) Network definition: This category refers to the definition of actors and the social relations of interest between them (Wassermann and Faust 1994), e.g., farmers, households, or institutions and the exchange of material support, information, or knowledge; as well as to the definition of the scale of interaction (Prell 2011), e.g., cooperation between different levels at different administrative or geographical scales.

b.(3) Network analysis: With this category, we indicate on which network level the analysis focuses, e.g., the individual actor, the subgroup, or the network level (Bodin and Crona 2009, Bodin and Prell 2011), and which specific characteristics are highlighted, e.g., actor, tie, or structural characteristics or network context (Entwisle et al. 2007, Doreian and Conti 2012).

General categories were used to be able to account for a broad spectrum of case studies. In reality, categorization is not a clearcut process, and studies could be attributed to more than one category. Hence, except for the network approach, we allowed multiple nominations, for example, a combination of network narratives. At the same time, we took into account that categories might not be applicable in all cases. For example, a study following a metaphorical approach might not be explicit about the network level or characteristics addressed.

\section{RESULTS}

Sixty case studies were selected for in-depth analysis: 22 studies from strand (i) natural resource governance, 17 studies from strand (ii) agricultural innovation, and 21 studies from strand (iii) social support. In the following, we present an overview of how these studies conceptualize and operationalize social networks and summarize key findings for each strand. We refer to general characteristics of each strand and highlight particular case studies only where they are needed to illustrate differences in the conceptualization and operationalization of social networks. Detailed information on each case study is provided in Appendix 1.

\section{Strand (i): Natural resource governance}

Research in this strand is concerned with the question of how social networks affect the ability to adaptively manage natural resources. The case studies deal with issues, ranging from climate policy (Moeliono et al. 2014) to water and dryland management (Stein et al. 2011, Sundstrom et al. 2012, de Villiers et al. 2014, Nuno et al. 2014, Mannetti et al. 2015) and coastal area management (Tompkins et al. 2002, Crona and Bodin 2006, 2010, Bodin and Crona 2008, Ramirez-Sanchez and Pinkerton 2009, Gelcich et al. 2010, Marín and Berkes 2010, Cohen et al. 2012, Marín et al. 2012, 2015, Cárcamo et al. 2014, Pietri et al. 2015).

\section{Network conceptualization}

Conceptual framing: Social networks are conceptualized as key factors for understanding collective action and learning in SES. Even if studies do not explicitly refer to resilience, they conceptualize social networks as central to the management of natural resources. Particular studies draw on concepts such as adaptive comanagement and hence implicitly refer to the resilience of SES (Marín and Berkes 2010, Stein et al. 2011, Moeliono et al. 2014, Apgar et al. 2015, Mannetti et al. 2015).

Network variable: Studies predominantly focus on the structure of social relations and their impact on management outcomes, treating social networks as an independent variable, though there 
are exceptions that take into account factors impacting social networks, such as ecological (Ramirez-Sanchez and Pinkerton 2009), economic (Rico García-Amado et al. 2012), and political changes (Ireland and Thomalla 2011, Sundstrom et al. 2012).

Network narrative: Underlying most studies is the conception of networks as a "form of coordination," either focusing particularly on the communication and knowledge flows between resource users at the community level (Crona and Bodin 2006, 2010), or with an emphasis on formal organizational networks (Gelcich et al. 2010, Stein et al. 2011, Cohen et al. 2012, Cárcamo et al. 2014, Moeliono et al. 2014, Nuno et al. 2014, Pietri et al. 2015). Furthermore, several studies refer to social networks as a structural feature of "social capital." In this way, they either explain the performance of particular organizations (Marín and Berkes 2010, Marín et al. 2012) and individual actors (RamirezSanchez and Pinkerton 2009, Rico García-Amado et al. 2012) or investigate the potential of collective action for conflict resolution (Sanginga et al. 2007) and disaster risk recovery (Ireland and Thomalla 2011, Marín et al. 2015).

\section{Network operationalization}

Network approach: Structurally explicit approaches, and in particular the application of SNA techniques, are characteristic of most studies in this strand, however, there are also studies that refer to social networks in metaphorical terms, treating networks as an binary variable (Tompkins et al. 2002, Sanginga et al. 2007, Gelcich et al. 2010, Sundstrom et al. 2012).

Network definition: The social relations emphasized involve information, knowledge exchange, and collaboration between resource users and stakeholders. Network boundaries are defined with reference to management systems with a limited set of stakeholders and with clear ecological, geographical, or administrative boundaries. Whereas social ties in most cases are perceived as facilitating exchange and mutual understanding, few studies point to the restrictive potential of social ties (Marín and Berkes 2010, Marín et al. 2012). Several studies explicitly address cross-scale interactions between various political and administrative stakeholders (Tompkins et al. 2002, Gelcich et al. 2010, Stein et al. 2011, Cohen et al. 2012, Cárcamo et al. 2014, Marín et al. 2015).

Network analysis: The focus of research comprises the network, the subgroup, and the individual level, whereby the focus of analysis is on structural network characteristics such as density, centrality, or fragmentation. Common tie characteristics are those of importance, frequency, or intensity. Several studies distinguish between bonding, bridging, and linking ties (Sanginga et al. 2007, Bodin and Crona 2008, Ramirez-Sanchez and Pinkerton 2009, Stein et al. 2011, Cohen et al. 2012, Marín et al. 2012, 2015, Sundstrom et al. 2012, Cárcamo et al. 2014, Apgar et al. 2015). Few studies highlight the influence of network context (Tompkins et al. 2002, Rico García-Amado et al. 2012, Sundstrom et al. 2012) or actor characteristics, such as leadership or socioeconomic power (Bodin and Crona 2008, Crona and Bodin 2010) to explain agency or lack thereof.

\section{Key findings}

Studies identify heterogeneity, cross-scale interaction, network density, and actor centrality as key factors influencing the resilience of governance networks. For the latter two factors, dense and centralized networks with strong bonding ties are shown to be effective in managing simple tasks (Rico GarcíaAmado et al. 2012), while fragmented networks are shown to limit communication and hence adaptive capacity (Cárcamo et al. 2014, Mannetti et al. 2015). Furthermore, for successful transformation toward sustainable governance, studies indicate the need for decentralized and heterogeneous networks that entail bridging ties between administrative and institutional scales of management (Gelcich et al. 2010, Cohen et al. 2012, Marín et al. 2012, 2015) and, in particular, the need for brokers who facilitate collaboration between these scales (Stein et al. 2011, Cárcamo et al. 2014, Moeliono et al. 2014, Nuno et al. 2014, Pietri et al. 2015). Studies elaborating on possible reasons for inertia in governance processes reveal homogeneity among centrally positioned opinion-leaders as a potential barrier to collective action (Crona and Bodin 2006, 2010, Bodin and Crona 2008, Ramirez-Sanchez and Pinkerton 2009, Moeliono et al. 2014, Mannetti et al. 2015). Social capital based on linking ties (Marín et al. 2012) and flexible arrangements with changing roles and responsibilities are suggested as better suited to meeting the challenges of adaptive management (Apgar et al. 2015). Particular findings show that, successful governance networks can enhance resilience to natural disasters (Marín et al. 2015), but favorable structures alone might not be sufficient to promote proactive resilience building if resource users are excluded from formal institution building (Ramirez-Sanchez and Pinkerton 2009).

\section{Strand (ii): Agricultural innovation}

Research in this strand is concerned with processes of social learning in the context of rural transformation. The case studies reviewed, for example, range from acceptance of improved crop varieties (Bandiera and Rasul 2006, Van den Broeck and Dercon 2011, Tatlonghari et al. 2012, Thuo et al. 2014) through the implementation of sustainable and risk-mitigating agricultural practices (Mazzucato and Niemeijer 2000, Conley and Udry 2001, Isaac et al. 2007, 2014, Matuschke and Qaim 2009, Arora 2012, van Rijn et al. 2012, Matouš et al. 2013, Wossen et al. 2013) to the use of modern information and communication technologies (Butt 2015).

\section{Network conceptualization}

Conceptual framing: In contrast to studies in the other two research strands, the majority of literature in this strand does not address resilience explicitly. However, from a development economics' perspective, studies perceive of social networks as factors shaping social learning and adaptive changes in the context of agrarian change, and hence implicitly address aspects relevant to resilience. A system's perspective is rare, although there are attempts to embed it in the context of innovation systems (Spielman et al. 2011, Arora 2012, Isaac 2012). A few studies link agricultural innovation with adaptive management (Isaac et al. 2007) or conceptualize social networks as a form of social memory contributing to resilience (Isaac et al. 2014).

Network variable: The majority of studies focus on the outcomes of networks - here the adoption of agricultural practices or technologies - treating social networks as an independent variable. Studies that address the impact of external changes on social network structure are the exception (Mazzucato and Niemeijer 2000, Arora 2012, Isaac et al. 2014, Butt 2015).

Network narrative: Underlying most studies is the conception of networks as pipes through which "flows" of information, knowledge, and advice are transferred and circulated between 
actors. Less frequently, social networks are conceptualized as social capital, explaining differences in adaptation processes between different groups of farmers (Hoang et al. 2006, Tatlonghari et al. 2012, van Rijn et al. 2012).

\section{Network operationalization}

Network approach: In this strand, descriptive approaches predominate, characterized by an emphasis on econometric methods. A smaller number adopt structurally explicit approaches using methods of SNA (Isaac et al. 2007, 2014, Arora 2012, Spielman et al. 2011, Isaac 2012). Few studies adopt metaphorical approaches (Mazzucato and Niemeijer 2000, Butt 2015).

Network definition: The most frequently investigated social relation is information and advice sharing between farmers and external actors such as extension staff and NGOs (Arora 2012, Matouš et al. 2013, Wossen et al. 2013). Challenging the assumption that the village level is suitable for defining the reference group for social learning, specific studies compare innovation networks between different study sites, and highlight the role of information exchanges between villages (Mazzucato and Niemeijer 2000, Conley and Udry 2001, Matuschke and Qaim 2009, Isaac et al. 2014) and rural and urban areas (Isaac 2012, Wossen et al. 2013).

Network analysis: In contrast to studies in the governance strand, the dominant level of observation is not that of the network or subgroup but that of the individual farmer. For analysis, descriptive studies predominantly focus on actor and tie characteristics. Actor characteristics addressed include, for example, farm size, wealth, experience, gender, ethnicity, and geographic location, whereas tie characteristics addressed include kinship and friendship relations. The latter are referred to as strong or bonding ties (Van den Broeck and Dercon 2011, Tatlonghari et al. 2012), while relations to external actors and institutions are referred to as weak or bridging ties (Wossen et al. 2013, Thuo et al. 2014). Structurally explicit studies focus on structural measures for explaining information diffusion, such as network density and fragmentation, as well as on actor centrality for identifying brokers of agro-ecological knowledge (Isaac et al. 2007, 2014, Isaac 2012). Network context is addressed by a few studies highlighting the roles played by institutions (Hoang et al. 2006, Spielman et al. 2011, Arora 2012), information technologies (Butt 2015), or migration (Isaac et al. 2014).

\section{Key findings}

Studies do not explicitly elaborate on the link between network features and resilience. However, they identify key factors influencing social learning and decision-making processes and hence provide insights into adaptive processes crucial for the resilience of SES. In this regard, studies highlight actor and tie characteristics rather than network structure. Challenging the simple assumption that having more actors in a network increases the likelihood of adopting new technologies, studies reveal that decisions are based on imperfect knowledge and are oriented toward the experience and adoption behavior of network members (Conley and Udry 2001, Matuschke and Qaim 2009, Wossen et al. 2013), and are often subject to strategic considerations (Bandiera and Rasul 2006). Regarding tie characteristics, two groups of studies can be distinguished. The first group identifies social and geographical proximity as conducive to information diffusion: Strong and homophilous ties, for example kinship ties, are shown to facilitate information diffusion (Bandiera and Rasul 2006, Hoang et al. 2006, Matuschke and Qaim 2009, Van den Broeck and Dercon 2011, Tatlonghari et al. 2012). In contrast, the second group of studies emphasizes the role of bridging and linking ties between diverse actors from civil society, public extensions, and the private sector, which provide farmers with access to external sources of information and experiences (Arora 2012, van Rijn et al. 2012, Matouš et al. 2013, Wossen et al. 2013, Isaac et al. 2014, Thuo et al. 2014). Within this group, particular studies highlight geographical factors. First, ties to geographically distant actors increase the likelihood that farmers will gain access to new information (Wossen et al. 2013), and second, experiences gained from farming in different agro-ecological settings can help to build social memory (Isaac et al. 2014). With regard to network structure, those studies applying structurally explicit approaches argue that, unlike governance, innovation requires sparse but efficient networks with a few central actors acting as brokers between formal and informal networks (Isaac et al. 2007, 2014, Isaac 2012). Particular studies point to the critical roles played by elite actors linking external actors and the community, and the danger of reproducing power imbalances through external interventions (Hoang et al. 2006, Spielman et al. 2011, Arora 2012).

\section{Strand (iii): Social support}

Research in this strand focuses on reciprocity between rural households as a way of pooling scarce resources and as a means of household risk management. Case studies reviewed include, for example, work on social networks as part of rural livelihood strategies (Kadigi et al. 2007, Torkelsson 2007, Nygren and MyattHirvonen 2009, Ekblom 2012, Rindfuss et al. 2012, Goulden et al. 2013, Baird and Gray 2014), recovery from climate risks (Bosher et al. 2007, Rotberg 2010, Islam and Walkerden 2014, 2015), climate-change adaptation (Scheffran et al. 2012), and sustainable resource management (Downey 2010, Zimmerer 2014, Abizaid et al. 2015, Katikiro et al. 2015, Orchard et al. 2015).

\section{Network conceptualization}

Conceptual framing: The majority of studies in this strand conceptualize social networks as a source of resources supportive to the resilience of rural households and communities. Even studies not explicitly addressing resilience share the conceptualization of networks as coping strategy in times of need (Kadigi et al. 2007, Torkelsson 2007, Nygren and Myatt-Hirvonen 2009, Rindfuss et al. 2012, Gallego and Mendola 2013, Lyle and Smith 2014, Abizaid et al. 2015, Katikiro et al. 2015) and hence refer to particular aspects of resilience. Unlike studies focusing on governance and innovation, studies on social support more frequently take a community perspective conceiving of social networks as a means for communities to deal with external shocks and risks (Cassidy and Barnes 2012, Ekblom 2012, Baird and Gray 2014, Islam and Walkerden 2014, 2015).

Network variable: Studies tend to focus on the outcomes of social networks and therefore treat social networks as an independent variable. However, there are also studies treating social networks as a dependent variable, emphasizing how social support networks are influenced by the impact of socioeconomic factors, such as livelihood diversification (Baird and Gray 2014, Orchard 
et al. 2015), gender (Torkelsson 2007), caste influence (Bosher et al. 2007), and migration (Scheffran et al. 2012, Gallego and Mendola 2013, Zimmerer 2014).

Network narrative: Most studies in this strand refer to the notion of networks as social capital explaining differences in the vulnerability of households due to their different embeddedness. Unlike literature on agricultural innovations and governance, few studies in this strand build on the notion of networks functioning as pipes for the exchange of different types of support (Rindfuss et al. 2012, da Costa et al. 2013, Zimmerer 2014, Abizaid et al. 2015, Katikiro et al. 2015) or as a form of coordination (Downey 2010).

\section{Network operationalization}

Network approach: In comparison to the other two strands, this strand is characterized by a more equal presence of all three operational approaches. Descriptive approaches, characterizing social networks according to the nature of the ties involved, account for the majority. Metaphorical approaches that refer to either the existence or the decline of social networks as an explanatory variable of resilience are more frequent than in other strands (Kadigi et al. 2007, Ekblom 2012, Scheffran et al. 2012, da Costa et al. 2013, Zimmerer 2014, Katikiro et al. 2015). Structurally explicit approaches, drawing on methods of SNA (Downey 2010, Cassidy and Barnes 2012, Lyle and Smith 2014, Abizaid et al. 2015, Orchard et al. 2015) are more frequent than in the strand of agricultural innovation but less frequent than in the governance strand.

Network definition: The dominant social relation of interest is the exchange of material, financial, and emotional support between rural households at the village level. Studies tend to concentrate on the village level (Cassidy and Barnes 2012, Islam and Walkerden 2014, Lyle and Smith 2014, Abizaid et al. 2015), though there are also studies emphasizing the role of social ties that extend beyond the community (Ekblom 2012, Rindfuss et al. 2012, Scheffran et al. 2012, Gallego and Mendola 2013, Islam and Walkerden 2015, Orchard et al. 2015).

Network analysis: The main level of analysis is that of the individual, in this case, households, whereas structurally explicit studies also give attention to the network level (Cassidy and Barnes 2012, Lyle and Smith 2014). Frequently addressed characteristics include tie reciprocity and tie strength, the latter being operationalized either as bonding ties of kinship and bridging ties of neighborhood and friendship (Islam and Walkerden 2014, 2015), or as bonding ties within the community and bridging ties to actors outside the community (Rotberg 2010, Baird and Gray 2014, Islam and Walkerden 2014, 2015, Orchard et al. 2015). Compared to other strands, there is a stronger focus on network context, including social institutions and socioeconomic changes (Torkelsson 2007, Nygren and MyattHirvonen 2009, Baird and Gray 2014, Katikiro et al. 2015, Orchard et al. 2015). Structurally explicit studies focus on structural characteristics such as density, hierarchy, and the centrality of particular households (Downey 2010, Cassidy and Barnes 2012, Lyle and Smith 2014, Orchard et al. 2015).

\section{Key findings}

Regarding the coping aspect of social networks, several studies emphasize the importance of strong ties of reciprocity and trust at the community level (Kadigi et al. 2007, da Costa et al. 2013, Goulden et al. 2013, Katikiro et al. 2015) or, more specifically, to the combination of strong and weak ties (Rotberg 2010, Islam and Walkerden 2014, 2015). Particular studies point to the importance of temporal dynamics by revealing that the composition and viability of bridging and bonding ties is not fixed but changes over time (Baird and Gray 2014, Islam and Walkerden 2014). Network transitions from traditional support systems to diversified market-oriented networks are shown to have ambiguous implications for community resilience. For example, transitions might foster the capacity to cope with high-incidence/ low-severity impacts, while at the same time reduce the ability to manage low-incidence/high-severity shocks (Baird and Gray 2014, Orchard et al. 2015). With regard to actor characteristics, studies show that gender and socioeconomic status determine access to and ability to utilize social networks (Bosher et al. 2007, Torkelsson 2007, Cassidy and Barnes 2012, Rindfuss et al. 2012, Abizaid et al. 2015). Taking into account network structure, some studies conclude that more central households are more resilient because they can access more resources (Cassidy and Barnes 2012, Lyle and Smith 2014). Dense networks are shown to have higher redundancy and hence better opportunities to mobilize resources and act collectively, while larger and less redundant networks might yield greater returns (Orchard et al. 2015). Taking into account the effect of external factors on support networks, a small group of studies indicates the effects of migration either on participation in community networks (Gallego and Mendola 2013), or on livelihoods and resilience in the places of origin (Ekblom 2012, Rindfuss et al. 2012, Scheffran et al. 2012).

\section{DISCUSSION}

This review of case studies on the role of social networks in the Global South extends beyond disciplinary boundaries. Its categorization system permits the different strands to be compared and thus allows similarities, differences, and blind spots to be revealed. This opens up the opportunity to critically assess the viability of a social network perspective for addressing the resilience of rural communities in the Global South as well as to discuss implications for future research.

\section{Strengths, weaknesses, and challenges of current social network research in the Global South}

\section{Strand (i): Natural resource governance}

Approaching social networks from a systems perspective, this strand addresses the capacity of social networks to navigate the transformation of SES toward sustainable resource use and resilience. A particular strength of this approach lies in linking social network patterns with particular resilience features (Newman and Dale 2005, Janssen et al. 2006). Against this background, studies provide instructions for strengthening the resilience of governance systems; they offer opportunities to identify cross-scale mismatches and barriers in governance processes (e.g., Crona and Bodin 2006, Stein et al. 2011, Moeliono et al. 2014, Nuno et al. 2014), to recognize potential change agents (e.g., Crona and Bodin 2010, Cárcamo et al. 2014, Moeliono et al. 2014), to design more sustainable governance regimes (e.g., Gelcich et al. 2010, Cohen et al. 2012, Marín et al. 2012, 2015, Pietri et al. 2015). In doing so, they can draw on the elaborated toolkit of SNA, which is increasingly applied not only in the context of resource governance in the Global South but around 
the globe (Bodin and Prell 2011). Particularly promising in this regard is the application of SNA for disentangling coupled SES and for investigating the alignment of social and ecological structures and processes (Bodin and Tengö 2012, Bodin et al. 2014, Roldán et al. 2015).

Structurally explicit approaches, as applied in most studies, have their drawbacks, however. Formal assessment of network structure requires clearly defined network boundaries (Scott 2013), a methodological restriction in the context of dynamic rural societies. As well, the focus on definable management systems tends to ignore particularities of resource governance in the Global South, such as social, economic, and political conditions impacting the livelihoods, needs, and rationalities of stakeholders. Another drawback stems from the underlying assumption that exchange and communication between various actors inevitably increases understanding and the willingness to act collectively (Schneider et al. 2003, Carlsson and Sandström 2008, Newig et al. 2010). This collaborative bias tends to downplay conflicts underlying many current resource management issues in the Global South (McNeish 2010), in particular the role of power asymmetries (Crona and Bodin 2010). A technical and apolitical understanding of governance is problematic because it portrays resource conflicts as a manageable task involving the modification of network patterns (Zimmer and Sakdapolrak 2012, Scott 2015). In the same way, any argument that SNA can be used as a tool to improve governance processes and hence contribute to resilience runs the risk of reducing resilience building to a mere technical challenge (Scott 2015).

Instead of assuming that favorable network patterns will "lubricate the machinery of natural resource governance" (Crona and Hubacek 2010), more attention should be paid to the skills, means, and motivation of centrally positioned actors to promote new ideas and prompt collective action (Crona and Bodin 2010, Moore and Westley 2011). A critical approach to governance ought to address the question of what mode of social-ecological interactions promotes specific governance systems and whose resilience this might foster or impede (Cretney 2014). This would also entail a stronger emphasis on the social and historical context of resource governance in the Global South.

\section{Strand (ii): Agricultural innovation}

In contrast to the system perspective of the governance strand, this strand adopts an actor-based perspective on the capacity of social networks to promote adaptive capacity through social learning and the adoption of technology in the context of agrarian change. Its strength lies in accounting for a variety of actor and tie characteristics (e.g., Conley and Udry 2001, Bandiera and Rasul 2006, Tatlonghari et al. 2012, Thuo et al. 2014) as well as social, political, and religious factors (e.g., Mazzucato and Niemeijer 2000, Matouš et al. 2013). Building on descriptive approaches utilizing sophisticated econometric methods, studies in this strand are less restricted by defining boundaries and are more conscious of the relevance of relations that cross geographic scales (e.g., Matuschke and Qaim 2009, Isaac 2012, van Rijn et al. 2012, Wossen et al. 2013, Isaac et al. 2014). Although studies do not explicitly address the links between social networks and resilience, they provide valuable information about how sustainable innovations, and hence adaptive capacity, can be promoted by research, development, and policy. (e.g., Hoang et al. 2006, Spielman et al. 2011, Van den Broeck and Dercon 2011).
Although the descriptive approaches offer greater flexibility in the network definition than structurally explicit approaches, they are limited in their ability to assess network structure. Furthermore, using network proxies such as group membership involves methodological problems. First, farmers might adopt or choose group membership because of unobserved individual characteristics or hidden variables. Second, the behavior of the group might influence the individual, who in turn might influence the group (Manski 1993). Ways of circumventing these problems have been suggested (Bandiera and Rasul 2006, Matuschke and Qaim 2009). However, these adjustments do not account for the simplistic conceptualization of networks as pipes, which tends to oversimplify decision-making processes in rural contexts. This omission is of particular relevance because work on social contagion (Burt 1987) suggests that social actors align their behavior with reference not only according to directly available information but also according to perceived norms and roles regarding their positions within a given network structure (Burt 1987, Grabher 2006). Of further concern is the strand's bias toward economic explanations of decision making, which downplay the roles of social, political, and environmental aspects in mediating the social and economic values of innovations.

Seen from a systemic perspective, a major factor that stands in the way of understanding resilience is the strand's focus on decisions at the individual level. Understanding how social networks facilitate or impede the adoption of more sustainable agricultural practices is a major, but not a sufficient, basis upon which to make claims about the resilience of SES (Carpenter et al. 2001). As a way forward, studies that approach innovation networks from a systems' perspective (Spielman et al. 2011, Isaac 2012) and link them to concepts such as adaptive management and social memory (Isaac et al. 2014) might be instructive in addressing multiscale interactions and positioning them in social, political, and cultural contexts (Atwell et al. 2008).

\section{Strand (iii): Social support}

This strand provides insights into the ways in which households employ their social networks as a strategy to cope with and recover from risks. Its strengths lie in providing a community perspective on household coping strategies and in employing a multimethod mix comprising quantitative and qualitative aspects of social networks. This combination offers the flexibility to take into account actor, tie, and network characteristics, as well as the impact of network context such as social institutions (e.g., Bosher et al. 2007, Torkelsson 2007, Nygren and Myatt-Hirvonen 2009) and socioeconomic changes (e.g., Baird and Gray 2014, Zimmerer 2014, Katikiro et. al 2015, Orchard et al. 2015). Furthermore, in contrast to the strands of governance and innovation research, studies in this strand more explicitly account for the temporal dynamics of social networks (e.g., Rindfuss et al. 2012, Goulden et al. 2013, Islam and Walkerden 2014), and hence provide a more nuanced understanding of how the resilience of rural households evolves in the context of rural transformation (Rigg 2006).

One particular issue of concern, however, stems from reducing social networks to "assets" that households have at their disposal. A tendency to reiterate tautological assumptions about the positive role of social capital (Nygren and Myatt-Hirvonen 2009) is particularly prevalent in metaphorical approaches that consider the mere existence of networks. This is a one-sided perspective, because networks are not necessarily solely beneficial but may 
also exclude actors from community resources and reinforce dependencies and differences between the actors (Bohle 2006, Torkelsson 2007, Steinbrink 2009). Furthermore, networks are not always readily available but involve time and resources to maintain (Nygren and Myatt-Hirvonen 2009, Lyle and Smith 2014), and their effectiveness might be limited by risks faced by its members (Gallego and Mendola 2013). Accordingly, participation in community networks is an ambiguous proxy for resilience, not least because it excludes those who cannot afford to be part of the network (Torkelsson 2007, Cassidy and Barnes 2012). Another drawback of studies in this strand is their tendency to conceive of social networks as consisting of strong bonding ties as relations of reciprocity and trust. Indeed, a bias toward reciprocal ties neglects the fact that norms of reciprocity, in particular between close family and kin, can exert high social pressure, and hence weak ties might be prioritized when seeking support (Nygren and Myatt-Hirvonen 2009).

In terms of the resilience of rural communities, it is not only problematic to confuse social proximity with the degree of support but also problematic to narrowly focus on the community level as the primary level of social interaction. Studies taking into account the impact of external actors on the resilience of rural households (e.g., Islam and Walkerden 2014, 2015) are providing important insights on the impact of external factors but might not be sufficient to address the mobility of rural livelihoods in the Global South (Ellis 2003, Rigg 2006). Rather studies should shift attention toward social ties spanning different locations to address coping capacity in an increasingly connected world (Scheffran et al. 2012).

\section{General challenges}

Besides the strengths and weaknesses of each research strand, our review also identifies general challenges: current case studies on the role of social networks tend to provide a static view of network outcomes, emphasize structure over agency, and neglect the spatial dimensions of social relations. A general challenge that has to be met by future social network research in the Global South is the tendency to abstract social structure from network context (Entwisle et al. 2007). Indeed, the majority of studies focus on the outcomes of networks rather than on the question of how social networks evolve in the context of change (Baird and Gray 2014). In most cases, studies addressing the impact of external drivers such as socioeconomic and political factors are following metaphorical or descriptive approaches and thus tend to remain silent about impacts in terms of network structure. Structurally explicit approaches that could provide these insights often fail to make sense of network context. Building on heuristic assumptions about how structural patterns are related to resilience features (Bodin et al. 2006, Janssen et al. 2006), studies following an analytical explicit approach tend to make general judgments about "trade-offs" between structural features and the "right mix" of ties instead of addressing the quality of ties for particular purposes (Videras 2013) and identifying contextual aspects of social interaction (De Nooy 2013). Moreover, studies tend to focus on the assessment of networks at a given point in time. In dynamic contexts, such as that of rural transformation, however, assessing "network snapshots" (Ernstson et al. 2008) is not sufficient to make causal claims about resilience in the long term (Bodin and Prell 2011). This applies in particular when taking into account that SES evolve through adaptive cycles
(Gunderson and Holling 2002) and that changing systems configurations might require different social networks (Downey 2010, Goulden et al. 2013). Studies using long-term panel surveys might overcome this challenge but are time and resource consuming (Rindfuss et al. 2012).

A much-discussed issue in network research is its inability to address the dialectical relationship between social structure and agency (Crona et al. 2011). This problem arises in the majority of our sample studies, which implicitly or explicitly build on the assumption that the presence of favorable networks is sufficient to ensure agency, here the ability to identify and enact solutions to sustainable development challenges (Newman and Dale 2007). However, addressing only one part of the iterative cycle between social processes and social structure (Bodin and Prell 2011) fails to make sense of the mechanisms through which social relations are reproduced and configured over time (Emirbayer and Goodwin 1994). Treating social structure "as is" (Bodin and Prell 2011:365) does not reflect how that structure evolves through communicative processes (Fuhse and Mützel 2010, Ingram et al. 2014) and neglects the critical role played by the means, skills, and motivation of particular social actors who "make things happen" (Crona et al. 2011:53) and, in particular, how they create social networks conducive to resilience (Moore and Westley 2011).

Finally, a further bias of current network research is its tendency not to take the spatial dimensions of social networks seriously. Indeed, most studies reviewed adopt a network-centric perspective, with a one-sided conception of horizontal and frictionless social "spaces of flows" (Jessop et al. 2008:391). In general, spatial assumptions underpinning social inquiries should be treated with caution (Jessop et al. 2008) to avoid falling into the trap of determinism. In the context of the Global South, where mobility and multiple connections between rural and urban areas are the norm rather than the exception (Ellis 2003, Steinbrink 2009), a spatially blind form of social network research, however, risks losing sight of significant determinants of rural livelihoods. Migration is a major strategy for livelihood diversification (Rigg 2006, World Bank 2011) and climate change adaptation (Black et al. 2011) and hence should be accounted for in studies addressing the role of social networks for the resilience of rural communities (Rindfuss et al. 2012, Scheffran et al. 2012, Gallego and Mendola 2013, Isaac et al. 2014).

Although all three challenges could apply to networks research in general, we argue that they are of particular concern for understanding the role of social networks for the resilience of rural communities in the Global South. Current social network research, with its static focus on network outcomes and its inability to take social agency sufficiently into account, is ill suited to addressing temporal and spatial dynamics in factually highly mobile societies (Ellis 2003, Rigg 2006). Furthermore, it provides an ahistorical perspective on social networks that tends to mask the political nature and colonial history of resource conflicts (McNeish 2010).

\section{Toward a translocal social network perspective}

Against the backdrop of these challenges, we envisage a social network perspective on resilience that takes into account the complexity and dynamics of rural livelihoods in an increasingly connected world. As a means to this end, we propose integrating research on social networks and resilience with the concept of translocality (Greiner and Sakdapolrak 2013a). 
The concept of translocality addresses the increasing connectedness of daily life, which is inter alia facilitated by multiple forms of mobility, including everyday movements, and seasonal and long-term migration (Brickell and Datta 2011). By emphasizing the simultaneous embeddedness of social actors in translocal networks spanning different locales, translocality combines the socio-spatial dimensions of both place and social networks (Jessop et al. 2008). It thereby challenges dichotomous geographical conceptions such as space/place, rural/urban, and core/periphery (Steinbrink 2009, Greiner and Sakdapolrak $2013 b$ ). Instead of conceiving of migration as a singular and unidirectional movement of people, translocality highlights the importance of migration-induced feedback processes between areas of origin and destination. This includes the circulation and flows of ideas, symbols, knowledge, and practices between mobile and nonmobile actors through translocal social networks (Greiner and Sakdapolrak 2013a). Hence, embeddedness in these translocal networks determines the availability of and access to resources and therefore has the potential to strengthen the resilience of its actors (Scheffran et al. 2012, Sakdapolrak 2014).

Accordingly, the notion of translocal resilience points to the role of translocal networks in conditioning the capacity of particular actors, households, and communities to cope with and adapt to changes, transform livelihoods, and explore alternative modes of social-ecological interaction (Sakdapolrak 2014, Sakdapolrak et al. 2016). These capacities in turn impact the means and opportunities to shape and utilize translocal networks. In other words, translocal networks are both preconditions and outcomes of the resilience of rural communities. By acknowledging that different capacities at individual, household, and community level are not necessarily complementary but might compete with each other, the notion of translocal resilience places particular emphasis on the role of social norms and power asymmetries in negotiating and defining desirable resilience outcomes. In other words, it provides a "situated" approach to resilience that broadens the scope of research toward including the processes and social relations that support resilience (Cote and Nightingale 2012).

A translocal network perspective, we claim, holds promise for addressing the challenges faced by current research on social networks and resilience in the Global South. First, by integrating the socio-spatial dimensions of networks and place, a translocal network perspective shifts the research focus from locally bound entities, such as the village, a region, or a management area, to the connectedness between actors at different places, while, at the same time, emphasizing the role of spatiality in social networks. Second, by taking into account mutual feedback processes between areas of origin and destination, it facilitates a dynamic understanding of complex rural transformations that cannot be understood by focusing on locally bound networks only. Third, it draws attention to the dialectic relationship between social structure and agency by revealing how capacities of resilience are related to daily practices of mobile and nonmobile actors in utilizing and shaping their networks. In doing so, it has the potential to contribute to a resilience research "of fine nuances," in the sense of Bourdieu, which takes into account economic and social power relations from the local to the global level (Deffner et al. 2014). Finally, a translocal network perspective would be suited to overcoming the apolitical tendencies of both resilience and network theory through reassessing resilience and social networks from a critical sciences perspective (Scott 2015).

\section{CONCLUSION}

This review provides a systematic overview on the conceptualization and operationalization of social networks across three strands of research and a discussion of their strengths and weaknesses in addressing aspects of the resilience of rural communities in the Global South. Research on governance networks, rooted in SES research, predominantly conceptualizes social networks as a form of coordination in the context of management system transformation. With its bias toward methods of formal network analysis, studies are powerful in providing insights into how networks can facilitate cross-scale adaptive management and how structural patterns relate to key system features relevant for the resilience of SES. However, because of methodological constraints, studies are limited to clearly identifiable management systems and tend to underestimate the role of human agency and power asymmetries. Contrastingly, research on innovation networks, informed by development economics, centers around the conception of social networks as pipes of information exchange required for the adaptation to changing conditions. Econometric methods provide opportunities for assessing a wide range of factors relevant, for example, to the purposeful changes of crops and practices; however, they remain descriptive in nature and vague with regard to the impact of these changes on resilience on higher levels. Studies on social support, rooted in vulnerability and disaster research, address the role of social networks as a means of coping with shock. By conceptualizing social networks as social capital, studies in this strand help to broaden the scope of vulnerability and livelihoods research. However, they tend to focus on social networks as assets at the community level thereby omitting the role of migration-induced feedback processes between areas of origin and destination.

Opportunities for sharpening and developing future research agendas include inter alia a critical approach to governance networks that reconsiders the role of actors' differential agency and power asymmetries; an integration of actor- and systemsbased approaches to agricultural innovation networks; and finally a shift away from stressing reciprocal and trusting relations at the community level toward addressing support networks spanning multiple locales in the context of mobility and social, economic, and political changes. More specifically, the review points to central challenges to be met in future research on social networks and resilience in the Global South. These particularly include the tendency of current network research to focus on network outcomes and the difficulties involved in assessing network dynamics, an overemphasis of network structure while undertheorizing the role of agency in shaping and reproducing social networks, and the tendency to neglect spatial dimensions of social relations despite the highly mobile character of many rural societies.

To address these challenges, we propose linking future research with the concept of translocality. A translocal social network perspective on the resilience of rural communities addressing embeddedness in and connectedness between places shifts the focus of research from bounded entities toward the connections between places; it takes into account the dynamic 
interrelationship between structure and agency and provides a multidimensional conception of social relations. Hence, it offers a framework well suited to the complexity of rural-urban realities in the Global South.

Responses to this article can be read online at: http://www.ecologyandsociety.org/issues/responses. $\mathrm{php} / 9009$

\begin{abstract}
Acknowledgments:
This article is based on research within the frame of the project "Building Resilience through Translocality: Climate Change, Migration and Social Resilience of Rural Communities in Thailand" (TransRe: www.transre.org) funded by the German Federal Ministry of Education and Research, grant number 01LN1309A. The responsibility for the contents of this publication lies with the authors. We would like to thank Harald Sterly, University of Bonn, for input and support.
\end{abstract}

\section{LITERATURE CITED}

Abizaid, C., O. T. Coomes, Y. Takasaki, and S. Brisson. 2015. Social network analysis of peasant agriculture: cooperative labor as gendered relational networks. Professional Geographer 67:447-463. http://dx.doi.org/10.1080/00330124.2015.1006562

Adger, W. N. 2000. Social and ecological resilience are they related? Progress in Human Geography 24:347-364. http://dx.doi. org/10.1191/030913200701540465

Adger, W. N. 2003. Social capital, collective action, and adaptation to climate Change. Economic Geography 79:387-404. http://dx.doi. org/10.1111/j.1944-8287.2003.tb00220.x

Apgar, M. J., W. Allen, K. Moore, and J. Ataria. 2015. Understanding adaptation and transformation through indigenous practice: the case of the Guna of Panama. Ecology and Society 20 (1):45. http://dx.doi.org/10.5751/ES-07314-200145

Arora, S. 2012. Farmers' participation in knowledge circulation and the promotion of agroecological methods in South India. Journal of Sustainable Agriculture 36:207-235. http://dx.doi. org/10.1080/10440046.2011.620231

Atwell, R. C., L. A. Schulte, and L. M. Westphal. 2008. Linking resilience theory and diffusion of innovations theory to understand the potential for perennials in the U.S. Corn Belt. Ecology and Society 14(1):30. http://dx.doi.org/10.5751/es-02787-140130

Baird, T. D., and C. L. Gray. 2014. Livelihood diversification and shifting social networks of exchange: a social network transition? World Development 60:14-30. http://dx.doi.org/10.1016/j. worlddev.2014.02.002

Bandiera, O., and I. Rasul. 2006. Social networks and technology adoption in northern Mozambique. Economic Journal 116:869-902. http://dx.doi.org/10.1111/j.1468-0297.2006.01115.x

Berkes, F., J. Colding, and C. Folke, editors. 2003. Navigating socialecological systems: building resilience for complexity and change. Cambridge University Press, Cambridge, UK. http://dx.doi. org/10.1017/cbo9780511541957
Berkes, F., and H. Ross. 2013. Community resilience: toward an integrated approach. Society and Natural Resources 26:5-20. http://dx.doi.org/10.1080/08941920.2012.736605

Black, R., S. R. G. Bennett, S. M. Thomas, and J. R. Beddington. 2011. Climate change: migration as adaptation. Nature 478:447-449. http://dx.doi.org/10.1038/478477a

Bodin, Ö., and B. I. Crona. 2008. Management of natural resources at the community level: exploring the role of social capital and leadership in a rural fishing community. World Development 36:2763-2779. http://dx.doi.org/10.1016/j. worlddev.2007.12.002

Bodin, Ö., and B. I. Crona. 2009. The role of social networks in natural resource governance: What relational patterns make a difference? Global Environmental Change 19:366-374. http://dx. doi.org/10.1016/j.gloenvcha.2009.05.002

Bodin, Ö., B. Crona, and H. Ernstson. 2006. Social networks in natural resource management: What is there to learn from a structural perspective? Ecology and Society 11(2):r2. https://doi. org/10.5751/ES-01808-1102r02

Bodin, Ö., B. Crona, M. Thyresson, A.-L. Golz, and M. Tengö. 2014. Conservation success as a function of good alignment of social and ecological structures and processes. Conservation Biology 28:1371-1379. http://dx.doi.org/10.1111/cobi.12306

Bodin, Ö., and C. Prell, editors. 2011. Social networks and natural resource management. Cambridge University Press, Cambridge, UK. http://dx.doi.org/10.1017/cbo9780511894985

Bodin, Ö., S. Ramirez-Sanchez, H. Ernstson, and C. Prell. 2011. A social relational approach to natural resource governance. Pages 3-28 in Ö. Bodin and C. Prell, editors. Social networks and natural resource management. Cambridge University Press, Cambridge, UK. http://dx.doi.org/10.1017/cbo9780511894985.002

Bodin, Ö., and M. Tengö. 2012. Disentangling intangible socialecological systems. Global Environmental Change 22:430-439. http://dx.doi.org/10.1016/j.gloenvcha.2012.01.005

Bohle, H.-G. 2006. Soziales oder unsoziales Kapital in der Geographischen Verwundbarkeitsforschung. Geographische Zeitschrift 93:65-81.

Borgatti, S. P., and P. C. Foster. 2003. The network paradigm in organizational research: a review and typology. Journal of Management 29:991-1013. http://dx.doi.org/10.1016/S0149-2063 (03)00087-4

Borgatti, S. P., A. Mehra, D. J. Brass, and G. Labianca. 2009. Network analysis in the social sciences. Science 323:892-895. http://dx.doi.org/10.1126/science.1165821

Bosher, L., E. Penning-Rowsell, and S. Tapsell. 2007. Resource accessibility and vulnerability in Andhra Pradesh: caste and noncaste influences. Development and Change 38:615-640. http://dx. doi.org/10.1111/j.1467-7660.2007.00426.x

Bourdieu, P. 1986. The forms of capital. Pages 46-58 in J. Richardson, editor. Handbook of theory and research for the sociology of education. Greenwood Press, Westport, Connecticut, USA.

Brickell, K., and A. Datta. 2011. Translocal geographies. Spaces, places, connections. Ashgate, Farnham, UK. 
Burt, R. S. 1987. Social contagion and innovation: cohesion versus structural equivalence. American Journal of Sociology 92:1287-1335. http://dx.doi.org/10.1086/228667

Burt, R. S. 2000. The network structure of social capital. Research in Organizational Behavior 22:345-423. http://dx.doi.org/10.1016/ $\underline{\text { S0191-3085(00)22009-1 }}$

Butt, B. 2015. Herding by mobile phone: technology, social networks and the "transformation" of pastoral herding in East Africa. Human Ecology 43:1-14. http://dx.doi.org/10.1007/ s10745-014-9710-4

Cárcamo, P. F., R. Garay-Flühmann, and C. F. Gaymer. 2014. Collaboration and knowledge networks in coastal resources management: how critical stakeholders interact for multiple-use marine protected area implementation. Ocean \& Coastal Management 91:5-16. http://dx.doi.org/10.1016/j.ocecoaman.2014.01.007

Carlsson, L. G., and A. C. Sandström. 2008. Network governance of the commons. International Journal of the Commons 2:33-54. http://dx.doi.org/10.18352/ijc.20

Carpenter, S., B. Walker, J. M. Anderies, and N. Abel. 2001. From metaphor to measurement: resilience of what to what? Ecosystems 4:765-781. http://dx.doi.org/10.1007/s10021-001-0045-9

Cassidy, L., and G. D. Barnes. 2012. Understanding household connectivity and resilience in marginal rural communities through social network analysis in the village of $\mathrm{Habu}$, Botswana. Ecology and Society 17(4):11. http://dx.doi.org/10.5751/ ES-04963-170411

Cohen, P. J., L. S. Evans, and M. Mills. 2012. Social networks supporting governance of coastal ecosystems in Solomon Islands. Conservation Letters 5:376-386. http://dx.doi.org/10.1111/ j.1755-263X.2012.00255.X

Coleman, J. S., 1988. Social capital in the creation of human capital. American Journal of Sociology 94:S95-S120. http://dx. doi.org/10.1086/228943

Conley, T., and C. Udry. 2001. Social learning through networks: the adoption of new agricultural technologies in Ghana. American Journal of Agricultural Economics 83:668-673. http:// dx.doi.org/10.1111/0002-9092.00188

Cote, M., and A. J. Nightingale. 2012. Resilience thinking meets social theory: situating social change in socio-ecological systems (SES) research. Progress in Human Geography 36(4):475-489. http://dx.doi.org/10.1177/0309132511425708

Cretney, R. 2014. Resilience for whom? Emerging critical geographies of socio-ecological resilience. Geography Compass 8:627-640. http://dx.doi.org/10.1111/gec3.12154

Crona, B., and Ö. Bodin. 2006. What you know is who you know? Communication patterns among resource users as a prerequisite for co-management. Ecology and Society 11(2):7. http://dx.doi. org/10.5751/es-01793-110207

Crona, B., and Ö. Bodin. 2010. Power asymmetries in small-scale fisheries: a barrier to governance transformability? Ecology and Society 15(4):32. [online] URL: http://www.ecologyandsociety. org/vol15/iss4/art32/

Crona, B., H. Ernstson, C. Prell, M. Reed, and K. Hubacek. 2011. Combining social network approaches with social theories to improve understanding of natural resource governance. Pages 44-72 in Ö. Bodin and C. Prell, editors. Social networks and natural resource management. Cambridge University Press, Cambridge, UK. http://dx.doi.org/10.1017/cbo9780511894985.004

Crona, B., and K. Hubacek. 2010. The right connections: How do social networks lubricate the machinery of natural resource governance? Ecology and Society 15(4):18. [online] URL: http:// www.ecologyandsociety.org/vol15/iss4/art18/

da Costa, M. dJ, M. Lopes, A. Ximenes, A. d. R. Ferreira, L. Spyckerelle, R. Williams, H. Nesbitt, and W. Erskine. 2013. Household food insecurity in Timor-Leste. Food Security 5:83-94. http://dx.doi.org/10.1007/s12571-012-0228-6

Deffner, V., C. Haferburg, P. Sakdapolrak, M. Eichholz, B. Etzold, and B. Michel. 2014. Relational denken, Ungleichheiten reflektieren - Bourdieus Theorie der Praxis in der deutschsprachigen Geographischen Entwicklungsforschung. Geographica Helvetica 69:3-6. http://dx.doi.org/10.5194/gh-69-3-2014

De Nooy, W. 2013. Communication in natural resource management: agreement between and disagreement within stakeholder groups. Ecology and Society 18(2):44. http://dx.doi. org/10.5751/ES-05648-180244

de Villiers, A. C., K. J. Esler, and A. T. Knight. 2014. Social processes promoting the adaptive capacity of rangeland managers to achieve resilience in the Karoo, South Africa. Journal of Environmental Management 146:276-283. http://dx.doi.org/10.1016/ j.jenvman.2014.08.005

Doreian, P., and N. Conti. 2012. Social context, spatial structure and social network structure. Social Networks 34:32-46. http://dx. doi.org/10.1016/j.socnet.2010.09.002

Downes, B. J., F. Miller, J. Barnett, A. Glaister, and H. Ellemor. 2013. How do we know about resilience? An analysis of empirical research on resilience, and implications for interdisciplinary praxis. Environmental Research Letters 8:1-8. http://dx.doi. org/10.1088/1748-9326/8/1/014041

Downey, S. S. 2010. Can properties of labor-exchange networks explain the resilience of swidden agriculture? Ecology and Society 15(4):15. [online] URL: http://www.ecologyandsociety.org/vol15/ iss $4 / \operatorname{art} 15 /$

Ekblom, A. 2012. Livelihood security, vulnerability and resilience: a historical analysis of Chibuene, southern Mozambique. Ambio 41:479-489. http://dx.doi.org/10.1007/ s13280-012-0286-1

Ellis, F. 2003. A livelihoods approach to migration and poverty reduction. Paper Commissioned by the Department for International Development, London, UK. [online] URL: http:// citeseerx.ist.psu.edu/viewdoc/download?doi=10.1.1.553.5678\&rep= $\underline{\text { rep } 1 \& \text { type }=\text { pdf }}$

Emirbayer, M., and J. Goodwin. 1994. Network analysis, culture, and the problem of agency. American Journal of Sociology 99:1411-1454. http://dx.doi.org/10.1086/230450

Entwisle, B., K. Faust, R. R. Rindfuss, and T. Kaneda. 2007. Networks and contexts: variation in the structure of social ties. American Journal of Sociology 112:1495-1533. http://dx.doi. org/10.1086/511803 
Ernstson, H., S. Sörlin, and T. Elmqvist. 2008. Social movements and ecosystem services-the role of social network structure in protecting and managing urban green areas in Stockholm. Ecology and Society 13(2):39. [online] URL: http://www. ecologyandsociety.org/vol13/iss2/art39/

Etzold, B., S. Jülich, M. Keck, P. Sakdapolrak, T. Schmitt, and A. Zimmer. 2012. Doing institutions. A dialectic reading of institutions and social practices and its relevance for development geography. Erdkunde 66:185-195. http://dx.doi.org/10.3112/ erdkunde.2012.03.01

Folke, C. 2006. Resilience: the emergence of a perspective for social-ecological systems analyses. Global Environmental Change 16:253-267. http://dx.doi.org/10.1016/j.gloenvcha.2006.04.002

Folke, C., S. R. Carpenter, B. Walker, M. Scheffer, T. Chapin, and J. Rockström. 2010. Resilience thinking: integrating resilience, adaptability and transformability. Ecology and Society 15(4):20. [online] URL: http://www.ecologyandsociety.org/vol15/iss4/ $\underline{\operatorname{art} 20 /}$

Folke, C., T. Hahn, P. Olsson, and J. Norberg. 2005. Adaptive governance of social-ecological systems. Annual Review of Environment and Resources 30:441-473. http://dx.doi.org/10.1146/ annurev.energy.30.050504.144511

Fuhse, J., and S. Mützel, editors. 2010. Relationale Soziologie: Zur kulturellen Wende der Netzwerkforschung. VS Verlag für Sozialwissenschaften, Wiesbaden, Germany. http://dx.doi. org/10.1007/978-3-531-92402-1

Gallego, J. M., and M. Mendola. 2013. Labour migration and social networks participation in southern Mozambique. Economica 80:721-759. http://dx.doi.org/10.1111/ecca.12031

Gelcich, S., T. P. Hughes, P. Olsson, C. Folke, O. Defeo, M. Fernández, S. Foale, L. H. Gunderson, C. Rodríguez-Sickert, M. Scheffer, R. S. Steneck, and J. C. Castilla. 2010. Navigating transformations in governance of Chilean marine coastal resources. Proceedings of the National Academy of Sciences of the United States of America 107:16794-16799. http://dx.doi. org/10.1073/pnas.1012021107

Goulden, M. C., W. N. Adger, E. H. Allison, and D. Conway. 2013. Limits to resilience from livelihood diversification and social capital in lake social-ecological systems. Annals of the Association of American Geographers 103:906-924. http://dx.doi. org/10.1080/00045608.2013.765771

Grabher, G. 2006. Trading routes, bypasses, and risky intersections: mapping the travels of networks' between economic sociology and economic geography. Progress in Human Geography 30:163-189. http://dx.doi.org/10.1191/0309132506ph600oa

Greiner, C., and P. Sakdapolrak. 2013a. Translocality: concepts, applications and emerging research perspectives. Geography Compass 7:373-384. http://dx.doi.org/10.1111/gec3.12048

Greiner, C., and P. Sakdapolrak. 2013b. Rural-urban migration, agrarian change, and the environment in Kenya: a critical review of the literature. Population and Environment 34:524-553. http:// dx.doi.org/10.1007/s11111-012-0178-0

Gunderson, L. H., and C. S. Holling. 2002. Panarchy: understanding transformations in human and natural systems. Island Press, Washington, D.C., USA.
Henning, M., U. Brandes, J. Pfeffer, and I. Mergel. 2012. Studying social networks: a guide to empirical research. Campus Verlag, Frankfurt, Germany.

Henry, A. D., and B. Vollan. 2014. Networks and the challenge of sustainable development. Annual Review of Environment and Resources 39:583-610. http://dx.doi.org/10.1146/annurevenviron-101813-013246

Hoang, L. A., J.-C. Castella, and P. Novosad. 2006. Social networks and information access: implications for agricultural extension in a rice farming community in northern Vietnam. Agriculture and Human Values 23:513-527. http://dx.doi. org/10.1007/s10460-006-9013-5

Holling, C. S. 1973. Resilience and stability of ecological systems. Annual Review of Ecology and Systematics 4:1-23. http://dx.doi. org/10.1146/annurev.es.04.110173.000245

Ifejika Speranza, C., U. Wiesmann, and S. Rist. 2014. An indicator framework for assessing livelihood resilience in the context of social-ecological dynamics. Global Environmental Change 28:109-119. http://dx.doi.org/10.1016/j.gloenvcha.2014.06.005

Ingram, M., H. Ingram, and R. Lejano. 2014. What's the story? Creating and sustaining environmental networks. Environmental Politics 23:984-1002. http://dx.doi.org/10.1080/09644016.2014.919717

Ireland, P., and F. Thomalla. 2011. The role of collective action in enhancing communities' adaptive capacity to environmental risk: an exploration of two case studies from Asia. PLOS Currents Disasters. http://dx.doi.org/10.1371/currents.rrn1279

Isaac, M. E. 2012. Agricultural information exchange and organizational ties: the effect of network topology on managing agrodiversity. Agricultural Systems 109:9-15. http://dx.doi. org/10.1016/j.agsy.2012.01.011

Isaac, M. E., L. C. N. Anglaaere, D. S. Akoto, and E. Dawoe. 2014. Migrant farmers as information brokers: agroecosystem management in the transition zone of Ghana. Ecology and Society 19(2):56. [online] URL: http://dx.doi.org/10.5751/ES-06589-190256

Isaac, M. E., B. H. Erickson, S. Quashie-Sam, and V. R. Timmer. 2007. Transfer of knowledge on agroforestry management practices: the structure of farmer advice networks. Ecology and Society 12(2):32. http://dx.doi.org/10.5751/es-02196-120232

Islam, R., and G. Walkerden. 2014. How bonding and bridging networks contribute to disaster resilience and recovery on the Bangladeshi coast. International Journal of Disaster Risk Reduction 10:281-291. http://dx.doi.org/10.1016/j.ijdrr.2014.09.016

Islam, R., and G. Walkerden. 2015. How do links between households and NGOs promote disaster resilience and recovery?: a case study of linking social networks on the Bangladeshi coast. Natural Hazards 78:1707-1727. http://dx.doi.org/10.1007/ s11069-015-1797-4

Janssen, M. A., Ö. Bodin, J. M. Anderies, T. Elmqvist, H. Ernstson, R. R. J. McAllister, P. Olsson, and P. Ryan. 2006. Toward a network perspective of the resilience of socialecological systems. Ecology and Society 11(1):15. [online] URL: http://www.ecologyandsociety.org/vol11/iss1/art15/ http://dx.doi. org/10.5751/es-01462-110115 
Jessop, B., N. Brenner, and M. Jones. 2008. Theorizing sociospatial relations. Environment and Planning D 26:389-401. http://dx.doi.org/10.1068/d9107

Kadigi, R. M. J., N. S. Y. Mdoe, and G. C. Ashimogo. 2007. Collective arrangements and social networks: coping strategies for the poor households in the Great Ruaha Catchment in Tanzania. Physics and Chemistry of the Earth, Parts $A / B / C$ 32:1315-1321. http://dx.doi.org/10.1016/j.pce.2007.07.026

Katikiro, R., K. H. M. A. Deepananda, and E. Macusi. 2015. Interplay between perceived changes in fishery and social structures in Tanzanian coastal fishing communities. Fisheries Research 164:249-253. http://dx.doi.org/10.1016/j.fishres.2014.12.009

Keck, M., and P. Sakdapolrak. 2013. What is social resilience? Lessons learned and ways forward. Erdkunde 67:5-19. http://dx. doi.org/10.3112/erdkunde.2013.01.02

Lin, N. 1999. Building a network theory of social capital. Connections 22:28-51.

Lyle III, H. F., and E. A. Smith. 2014. The reputational and social network benefits of prosociality in an Andean community. Proceedings of the National Academy of Sciences of the United States of America 111:4820-4825. http://dx.doi.org/10.1073/ pnas. 1318372111

Mannetti, L. M., K. J. Esler, A. T. Knight and K. Vance-Borland. 2015. Understanding social networks to improve adaptive cogovernance with the $\neq$ Khomani Bushmen of the Kalahari, South Africa. Human Ecology 43:481-492. http://dx.doi.org/10.1007/ s10745-015-9760-2

Manski, C. F. 1993. Identification of endogenous social effects: the reflection problem. Review of Economic Studies 60:531-542. http://dx.doi.org/10.2307/2298123

Marín, A., and F. Berkes. 2010. Network approach for understanding small-scale fisheries governance: the case of the Chilean coastal co-management system. Marine Policy 34:851-858. http://dx.doi.org/10.1016/j.marpol.2010.01.007

Marín, A., Ö. Bodin, S. Gelcich, and B. Crona. 2015. Social capital in post-disaster recovery trajectories: insights from a longitudinal study of tsunami-impacted small-scale fisher organizations in Chile. Global Environmental Change 35:450-462. http://dx.doi. org/10.1016/j.gloenvcha.2015.09.020

Marín, A., S. Gelcich, J. C. Castilla, and F. Berkes. 2012. Exploring social capital in Chile's coastal benthic comanagement system using a network approach. Ecology and Society 17(1):13. http:// dx.doi.org/10.5751/ES-04562-170113

Matouš, P., Y. Todo, and D. Mojo. 2013. Roles of extension and ethno-religious networks in acceptance of resource-conserving agriculture among Ethiopian farmers. International Journal of Agricultural Sustainability 11:301-316. http://dx.doi. org/10.1080/14735903.2012.751701

Matuschke, I., and M. Qaim. 2009. The impact of social networks on hybrid seed adoption in India. Agricultural Economics 40:493-505. http://dx.doi.org/10.1111/j.1574-0862.2009.00393.x

Mazzucato, V., and D. Niemeijer. 2000. The cultural economy of soil and water conservation: market principles and social networks in eastern Burkina Faso. Development and Change 31:831-855. http://dx.doi.org/10.1111/1467-7660.00179

McNeish. J. A. 2010. Rethinking resource conflict. World Bank Development Report. Background Paper. World Bank, Washington, D.C., USA. http://dx.doi.org/10.1037/e601972012-001

Moeliono, M., C. Gallemore, L. Santoso, M. Brockhaus, and M. Di Gregorio. 2014. Information networks and power: confronting the "wicked problem" of REDD+ in Indonesia. Ecology and Society 19(2):9. http://dx.doi.org/10.5751/ES-06300-190209

Moore, M., and F. Westley. 2011. Surmountable chasms: networks and social innovation for resilient systems. Ecology and Society 16(1):5. http://dx.doi.org/10.5751/es-03812-160105

Newig, J., D. Günther, and C. Pahl-Wostl. 2010. Synapses in the network: learning in governance networks in the context of environmental management. Ecology and Society 15(4):24. [online] URL: http://www.ecologyandsociety.org/vol15/iss4/ $\underline{\operatorname{art} 24 /}$

Newman, L., and A. Dale. 2005. Network structure, diversity, and proactive resilience building: a response to Tompkins and Adger. Ecology and Society 10(1):r2. http://dx.doi.org/10.5751/ es-01396-1001r02

Newman, L., and A. Dale. 2007. Homophily and agency: creating effective sustainable development networks. Environment, Development and Sustainability 9:79-90. http://dx.doi.org/10.1007/ s10668-005-9004-5

Nuno, A., N. Bunnefeld, and E. Milner-Gulland. 2014. Managing social-ecological systems under uncertainty: implementation in the real world. Ecology and Society 19(2):52. http://dx.doi. org/10.5751/ES-06490-190252

Nygren, A., and O. Myatt-Hirvonen. 2009. 'Life here is just scraping by': livelihood strategies and social networks among peasant households in Honduras. Journal of Peasant Studies 36:827-854. http://dx.doi.org/10.1080/03066150903354023

Olsson, P., C. Folke, and F. Berkes. 2004. Adaptive comanagement for building resilience in social-ecological systems. Environmental Management 34:75-90. http://dx.doi.org/10.1007/s00267-003-0101-7

Orchard, S. E., L. C. Stringer, and C. H. Quinn. 2015. Impacts of aquaculture on social networks in the mangrove systems of northern Vietnam. Ocean \& Coastal Management 114:1-10. http:// dx.doi.org/10.1016/j.ocecoaman.2015.05.019

Petticrew, M., and H. Roberts. 2006. Systematic reviews in the social sciences: a practical guide. Blackwell Publishing, Malden, UK. http://dx.doi.org/10.1002/9780470754887

Pietri, D. M., T. C. Stevenson, and P. Christie. 2015. The coral triangle initiative and regional exchanges: strengthening capacity through a regional learning network. Global Environmental Change 33:165-176. http://dx.doi.org/10.1016/j.gloenvcha.2015.05.005

Podolny, J. M. 2001. Networks as the pipes and prisms of the market. American Journal of Sociology 107:33-60. http://dx.doi. org/10.1086/323038

Portes, A. 1998. Social capital: its origins and applications in modern sociology. Annual Review of Sociology 24:1-24. http://dx. doi.org/10.1146/annurev.soc.24.1.1 
Putnam, R. D. 2000. Bowling alone: the collapse and revival of the American community. Simon \& Schuster, New York, New York, USA.

Powell, W. W. 1990. Neither market nor hierarchy - network forms of organization. Research in Organizational Behavior 12:295-336.

Prell, C. 2011. Some basic structural characteristics of networks. Pages 29-43 in Ö. Bodin and C. Prell, editors. Social networks and natural resource management. Cambridge University Press, Cambridge, UK. http://dx.doi.org/10.1017/cbo9780511894985.003

Ramirez-Sanchez, S., and E. Pinkerton. 2009. The impact of resource scarcity on bonding and bridging social capital: the case of fishers' information-sharing networks in Loreto, BCS, Mexico. Ecology and Society 14(1):22. [online] URL: http://www. ecologyandsociety.org/vol14/iss1/art22/

Rico García-Amado, L., M. Ruiz Pérez, I. Iniesta-Arandia, G. Dahringer, F. Reyes, and S. Barrasa. 2012. Building ties: social capital network analysis of a forest community in a biosphere reserve in Chiapas, Mexico. Ecology and Society 17(3):3. http:// dx.doi.org/10.5751/ES-04855-170303

Rigg, J. 2006. Land, farming, livelihoods, and poverty: rethinking the links in the rural South. World Development 34:180-202. http:// dx.doi.org/10.1016/j.worlddev.2005.07.015

Rindfuss, R. R., M. Piotrowski, B. Entwisle, J. Edmeades, and K. Faust. 2012. Migrant remittances and the web of family obligations: ongoing support among spatially extended kin in north-east Thailand, 1984-94. Population Studies 66:87-104. http://dx.doi.org/10.1080/00324728.2011.644429

Roldán, V. A., S. Villasante, and L. Outeiro. 2015. Linking marine and terrestrial ecosystem services through governance social networks analysis in central Patagonia (Argentina). Ecosystem Services 16:390-402. http://dx.doi.org/10.1016/j.ecoser.2015.02.010

Rotberg, F. J. Y. 2010. Social networks and adaptation in rural Bangladesh. Climate and Development 2:65-72. http://dx.doi. org/10.3763/cdev.2010.0031

Sakdapolrak, P. 2014. Building resilience through translocality. Climate change, migration and social resilience of rural communities in Thailand. TransRe Working Paper No. 1, Department of Geography, University of Bonn, Bonn, Germany.

Sakdapolrak, P., S. Naruchaikusol, K. Ober, S. Peth, L. Porst, T. Rockenbauch, and V. Tolo. 2016. Migration in a changing climate. Towards a translocal social resilience approach. Die Erde 147:81-94.

Sanginga, P. C., R. N. Kamugisha, and A. M. Martin. 2007. The dynamics of social capital and conflict management in multiple resource regimes: a case of the southwestern highlands of Uganda. Ecology and Society 12(1):6. http://dx.doi.org/10.5751/ es-01847-120106

Scheffran, J., E. Marmer, and P. Sow. 2012. Migration as a contribution to resilience and innovation in climate adaptation: social networks and co-development in Northwest Africa. Applied Geography 33:119-127. http://dx.doi.org/10.1016/j.apgeog.2011.10.002

Schneider, M., J. Scholz, M. Lubell, D. Mindruta, and M. Edwardsen. 2003. Building consensual institutions: networks and the National Estuary Program. American Journal of Political Science 47:143-158. http://dx.doi.org/10.1111/1540-5907.00010

Scott, J. 2011. Social network analysis: developments, advances, and prospects. Social Network Analysis and Mining 1:21-26. http:// dx.doi.org/10.1007/s13278-010-0012-6

Scott, J. 2013. Social network analysis. Third edition. SAGE Publications, London, UK. http://dx.doi.org/10.1177/00380385$\underline{88022001007}$

Scott, M. 2015. Re-theorizing social network analysis and environmental governance: insights from human geography. Progress in Human Geography 39:449-463. http://dx.doi. org/10.1177/0309132514554322

Skerratt, S. 2013. Enhancing the analysis of rural community resilience: evidence from community land ownership. Journal of Rural Studies 31:36-46. http://dx.doi.org/10.1016/j.jrurstud.2013.02.003

Spielman, D. J., K. Davis, M. Negash, and G. Ayele. 2011. Rural innovation systems and networks: findings from a study of Ethiopian smallholders. Agriculture and Human Values 28:195-212. http://dx.doi.org/10.1007/s10460-010-9273-y

Stein, C., H. Ernstson, and J. Barron. 2011. A social network approach to analyzing water governance: the case of the Mkindo catchment, Tanzania. Physics and Chemistry of the Earth, Parts A/B/C 36:1085-1092. http://dx.doi.org/10.1016/j.pce.2011.07.083

Steinbrink, M. 2009. Leben zwischen Land und Stadt. Migration, Translokalität und Verwundbarkeit in Südafrika. VS Verlag für Sozialwissenschaften, Wiesbaden, Germany. http://dx.doi. org/10.1007/978-3-531-91494-7

Sundstrom, S., J. F. Tynon, and D. Western. 2012. Rangeland privatization and the Maasai experience: social capital and the implications for traditional resource management in southern Kenya. Society \& Natural Resources 25:483-498. http://dx.doi. org/10.1080/08941920.2011.580420

Tatlonghari, G., T. Paris, V. Pede, I. Siliphouthone, and R. Suhaeti. 2012. Seed and information exchange through social networks: the case of rice farmers of Indonesia and Lao PDR. Sociology Mind 2:169-176. http://dx.doi.org/10.4236/sm.2012.22022

Thuo, M., A. A. Bell, B. E. Bravo-Ureta, M. A. Lachaud, D. K. Okello, E. N. Okoko, N. L. Kidula, C. M. Deom, and N. Puppala. 2014. Effects of social network factors on information acquisition and adoption of improved groundnut varieties: the case of Uganda and Kenya. Agriculture and Human Values 31:339-353. http://dx.doi.org/10.1007/s10460-014-9486-6

Tompkins, E., W. N. Adger, and K. Brown. 2002. Institutional networks for inclusive coastal management in Trinidad and Tobago. Environment and Planning A 34:1095-1111. http://dx.doi. org/10.1068/a34213

Torkelsson, А. 2007. Resources, not capital: a case study of the gendered distribution and productivity of social network ties in rural Ethiopia. Rural Sociology 72:583-607. http://dx.doi. org/10.1526/003601107782638710

Van den Broeck, K., and S. Dercon. 2011. Information flows and social externalities in a Tanzanian banana growing village. Journal of Development Studies 47:231-252. http://dx.doi. org/10.1080/00220381003599360 
van Rijn, F., E. Bulte, and A. Adekunle. 2012. Social capital and agricultural innovation in Sub-Saharan Africa. Agricultural Systems 108:112-122. http://dx.doi.org/10.1016/j.agsy.2011.12.003

Videras, J. 2013. Social networks and the environment. Annual Review of Resource Economics 5:211-226. http://dx.doi. org/10.1146/annurev-resource-091912-151912

Wassermann, S., and K. Faust. 1994. Social network analysis. Methods and applications. Cambridge University Press, Cambridge, UK. http://dx.doi.org/10.1017/cbo9780511815478

Walker, B., C. S. Holling, S. R. Carpenter, and A. Kinzig. 2004. Resilience, adaptability and transformability in social-ecological systems. Ecology and Society 9(2):5. http://dx.doi.org/10.5751/ es-00650-090205

Wilson, S., L. J. Pearson, Y. Kashima, D. Lusher, and C. Pearson. 2013. Separating adaptive maintenance (resilience) and transformative capacity of social-ecological systems. Ecology and Society 18(1):22. http://dx.doi.org/10.5751/es-05100-180122

Woolcock, M., and D. Narayan. 2000. Social capital: implications for development theory, research, and policy. World Bank Research Observer 15:225-249. http://dx.doi.org/10.1093/wbro/15.2.225

World Bank. 2011. Migration and remittances factbook 2011. Second edition. World Bank, Washington, D.C., USA. [online]: URL: http://siteresources.worldbank.org/INTLAC/Resources/ Factbook2011-Ebook.pdf

World Bank. 2016. World Bank country and lending groups. World Bank, Washington, D.C., USA. [online]: URL: http://data. worldbank.org/about/country-and-lending-groups

Wossen, T., T. Berger, T. Mequaninte, and B. Alamirew. 2013. Social network effects on the adoption of sustainable natural resource management practices in Ethiopia. International Journal of Sustainable Development \& World Ecology 20:477-483. http:// dx.doi.org/10.1080/13504509.2013.856048

Zimmer, A., and P. Sakdapolrak. 2012. The social practices of governing. Analysing waste water governance in a Delhi slum. Environment and Urbanization ASIA 3:325-341. http://dx.doi. org/10.1177/0975425312473228

Zimmerer, K. S. 2014. Conserving agrobiodiversity amid global change, migration, and nontraditional livelihood networks: the dynamic uses of cultural landscape knowledge. Ecology and Society 19(2):1. http://dx.doi.org/10.5751/ES-06316-190201 


\section{Appendix 1}

List of sample studies selected for in-depth analysis.

\section{A1.1: Strand i: Natural resource governance}

\begin{tabular}{|c|c|c|c|c|c|c|c|c|c|}
\hline \multirow[t]{3}{*}{ Authors } & \multirow[t]{3}{*}{ Research interest } & \multicolumn{3}{|c|}{ Conceptualization } & \multicolumn{4}{|c|}{ Operationalization } & \multirow[t]{3}{*}{ Key findings } \\
\hline & & \multirow{2}{*}{$\begin{array}{l}\text { Conceptual } \\
\text { framing }\end{array}$} & \multirow{2}{*}{$\begin{array}{l}\text { Network } \\
\text { variable }\end{array}$} & \multirow{2}{*}{$\begin{array}{l}\text { Network } \\
\text { narrative }\end{array}$} & \multirow[t]{2}{*}{ Network approach } & \multirow{2}{*}{$\begin{array}{l}\text { Network } \\
\text { definition }\end{array}$} & \multicolumn{2}{|c|}{ Network analysis } & \\
\hline & & & & & & & Network level & Network characteristics & \\
\hline $\begin{array}{l}\text { Apgar } \\
\text { et al. } 2015\end{array}$ & $\begin{array}{l}\text { Understand underly- } \\
\text { ing social dynamics at } \\
\text { play in social- } \\
\text { ecological systems in } \\
\text { indigenous territories } \\
\text { of Panama. }\end{array}$ & $\begin{array}{l}\text { Explicit reference to } \\
\text { resilience: } \\
\text { Social networks as } \\
\text { dynamic and informal } \\
\text { web of interactions } \\
\text { which foster adapta- } \\
\text { tion and transfor- } \\
\text { mation, and hence } \\
\text { resilience of social- } \\
\text { ecological systems. }\end{array}$ & $\begin{array}{l}\text { Independent: } \\
\text { Influence of networks } \\
\text { on adaptive capacity } \\
\text { of social-ecological } \\
\text { systems. }\end{array}$ & $\begin{array}{l}\text { Social capital: } \\
\text { Social networks as } \\
\text { part of social capital } \\
\text { helping to understand } \\
\text { the value of bridging } \\
\text { links across different } \\
\text { groups, communities, } \\
\text { and scales. }\end{array}$ & \begin{tabular}{|l|} 
Descriptive: \\
Reflection-groups \\
made up of leaders \\
and scholars engaged \\
in iterative discussion \\
cycles in an indige- \\
nous territory.
\end{tabular} & $\begin{array}{l}\text { Social relation: formal } \\
\text { / informal information } \\
\text { exchange. } \\
\text { Actors: community } \\
\text { members and leaders } \\
\text { involved in natural } \\
\text { resource governance. } \\
\text { Scale: regional / } \\
\text { indigenous territory + } \\
\text { linkages to external } \\
\text { actors. }\end{array}$ & $\begin{array}{l}\text { Subgroup: local } \\
\text { governance groups } \\
\text { Individual: brokers } \\
\text { between subgroups. }\end{array}$ & $\begin{array}{l}\text { Tie: bridging ties } \\
\text { connecting brokers } \\
\text { between groups, and } \\
\text { to outside actors. }\end{array}$ & $\begin{array}{l}\text { Changing roles of leaders prevent the } \\
\text { network from becoming vulnerable to the } \\
\text { loss of hubs and bridging links. } \\
\text { Cultural practices facilitating leadership } \\
\text { development and social networking are } \\
\text { critical for enabling both adaptation and } \\
\text { transformation. }\end{array}$ \\
\hline $\begin{array}{l}\text { Bodin and } \\
\text { Crona } 2008\end{array}$ & $\begin{array}{l}\text { Assess community } \\
\text { social capital and } \\
\text { identify potentially } \\
\text { influential actors in a } \\
\text { Kenyan coastal } \\
\text { village. Assess if lack } \\
\text { of community social } \\
\text { capital and leadership } \\
\text { may explain the lack } \\
\text { of collective action. }\end{array}$ & $\begin{array}{l}\text { Implicit reference to } \\
\text { resilience: } \\
\text { Social networks as a } \\
\text { factor fostering or } \\
\text { hindering collective } \\
\text { action towards sus- } \\
\text { tainable resource } \\
\text { management. }\end{array}$ & $\begin{array}{l}\text { Independent: } \\
\text { Influence of social } \\
\text { networks on collective } \\
\text { action. }\end{array}$ & $\begin{array}{l}\text { Social capital: } \\
\text { Characteristics of } \\
\text { social networks as a } \\
\text { factor of social capital. }\end{array}$ & \begin{tabular}{|l|} 
Structurally explicit: \\
Complete village / \\
household survey and \\
key informant inter- \\
views in a coastal \\
village. \\
SNA: total network.
\end{tabular} & $\begin{array}{l}\text { Social relation: per- } \\
\text { sonal support, } \\
\text { knowledge exchange, } \\
\text { gear lending. } \\
\text { Actors: fishermen } \\
\text { (household heads) in } \\
\text { the village. } \\
\text { Scale: local / village. }\end{array}$ & $\begin{array}{l}\text { Subgroup: occupa- } \\
\text { tional and relational } \\
\text { groups. } \\
\text { Individual: brokers } \\
\text { between subgroups. }\end{array}$ & $\begin{array}{l}\text { Actor: tribe, occupa- } \\
\text { tion, perception of } \\
\text { resource status. } \\
\text { Tie: ratio of bonding / } \\
\text { bridging ties. } \\
\text { Structure: density, } \\
\text { centrality. }\end{array}$ & $\begin{array}{l}\text { Unwillingness to report rule-breaking due } \\
\text { to strong social capital. } \\
\text { Homogeneity among key individuals } \\
\text { leading to poor recognition. } \\
\text { Brokers can block information flows and } \\
\text { act as social barriers to transformation. } \\
\text { Resilience depends on the impact of } \\
\text { central actors on decision making pro- } \\
\text { cesses. }\end{array}$ \\
\hline $\begin{array}{l}\text { Cárcamo } \\
\text { et al. } 2014 \\
\dagger\end{array}$ & $\begin{array}{l}\text { Investigate the struc- } \\
\text { ture and properties of } \\
\text { inter-organizational } \\
\text { social networks } \\
\text { involved in the use } \\
\text { and management of } \\
\text { natural resources in a }\end{array}$ & $\begin{array}{l}\text { Implicit reference to } \\
\text { resilience: } \\
\text { Structural properties } \\
\text { of social networks } \\
\text { influence co- } \\
\text { management ar- }\end{array}$ & $\begin{array}{l}\text { Independent: } \\
\text { Influence of networks } \\
\text { on management } \\
\text { outcome. }\end{array}$ & $\begin{array}{l}\text { Form of coordination: } \\
\text { Social networks as a } \\
\text { formal form of inter- } \\
\text { organizational com- } \\
\text { munication / collabo- }\end{array}$ & $\begin{array}{l}\text { Structurally explicit: } \\
\text { Document analysis, } \\
\text { stakeholder analysis, } \\
\text { and questionnaire } \\
\text { with organizational } \\
\text { representatives }\end{array}$ & $\begin{array}{l}\text { Social relation: infor- } \\
\text { mation, collaboration. } \\
\text { Actors: representa- } \\
\text { tives of organizations } \\
\text { / institutions. }\end{array}$ & $\begin{array}{l}\text { Network: governance } \\
\text { network. } \\
\text { Individual: cross-scale } \\
\text { brokers. }\end{array}$ & $\begin{array}{l}\text { Actor: organizational } \\
\text { type, administrative } \\
\text { level, perception, } \\
\text { homophily. } \\
\text { Tie: importance, } \\
\text { frequency, bridging }\end{array}$ & $\begin{array}{l}\text { Missing cross-scale interaction in co- } \\
\text { management networks potentially ham- } \\
\text { pers adaptive capacity and resilience of } \\
\text { social-ecological systems. } \\
\text { Centrally positioned actors could act as }\end{array}$ \\
\hline
\end{tabular}




\begin{tabular}{|c|c|c|c|c|c|c|c|c|c|}
\hline & $\begin{array}{l}\text { coastal marine eco- } \\
\text { system in Chile. }\end{array}$ & $\begin{array}{l}\text { rangements which } \\
\text { foster adaptive capac- } \\
\text { ity and resilience of } \\
\text { social-ecological } \\
\text { systems. }\end{array}$ & & ration. & $\begin{array}{l}\text { involved in the man- } \\
\text { agement of the } \\
\text { marine protected } \\
\text { area. } \\
\text { SNA: total network. }\end{array}$ & $\begin{array}{l}\text { Scale: local - national } \\
\text { governance system. }\end{array}$ & & $\begin{array}{l}\text { ties (between scales) } \\
\text { Structure: density, } \\
\text { diameter, average } \\
\text { path length, centrality. }\end{array}$ & bridging stakeholders. \\
\hline $\begin{array}{l}\text { Cohen } \\
\text { et al. } 2012\end{array}$ & $\begin{array}{l}\text { Understand the } \\
\text { potential of social } \\
\text { networks to facilitate } \\
\text { coordination and } \\
\text { learning among } \\
\text { management actors } \\
\text { involved in the marine } \\
\text { resource manage- } \\
\text { ment in Solomon } \\
\text { Islands. }\end{array}$ & $\begin{array}{l}\text { Implicit reference to } \\
\text { resilience: } \\
\text { Social networks as } \\
\text { factor of adaptive co- } \\
\text { management facilitat- } \\
\text { ing coordination and } \\
\text { learning among } \\
\text { management actors. }\end{array}$ & $\begin{array}{l}\text { Independent: } \\
\text { Influence of networks } \\
\text { on natural resource } \\
\text { governance outcome. }\end{array}$ & $\begin{array}{l}\text { Form of coordination: } \\
\text { Social networks as } \\
\text { purposeful formed } \\
\text { relations between } \\
\text { different actors foster- } \\
\text { ing collective action. }\end{array}$ & $\begin{array}{l}\text { Structurally explicit: } \\
\text { Qualitative interviews, } \\
\text { and questionnaire } \\
\text { with representatives } \\
\text { of organizations } \\
\text { involved in the gov- } \\
\text { ernance of marine } \\
\text { resources. } \\
\text { SNA: total network. }\end{array}$ & $\begin{array}{l}\text { Social relation: formal } \\
\text { / informal knowledge } \\
\text { exchange, collabora- } \\
\text { tion. } \\
\text { Actors: agencies and } \\
\text { organizations. } \\
\text { Scale: local - } \\
\text { international govern- } \\
\text { ance system. }\end{array}$ & $\begin{array}{l}\text { Network: governance } \\
\text { network. } \\
\text { Individual: bridging } \\
\text { organizations or } \\
\text { institutions. }\end{array}$ & $\begin{array}{l}\text { Actor: organization } \\
\text { type, scale of opera- } \\
\text { tion, preference for } \\
\text { learning. } \\
\text { Tie: intensity (strong / } \\
\text { weak), bridging ties } \\
\text { (between scales). } \\
\text { Structure: density, } \\
\text { centrality. }\end{array}$ & $\begin{array}{l}\text { Cross-scale communication transcending } \\
\text { formal governance systems facilitates } \\
\text { coordination and learning. } \\
\text { A trade-off exists between facilitating } \\
\text { flows of knowledge between various } \\
\text { levels and promoting learning on local } \\
\text { level. }\end{array}$ \\
\hline $\begin{array}{l}\text { Crona and } \\
\text { Bodin } 2006\end{array}$ & $\begin{array}{l}\text { Investigate if a lack of } \\
\text { collective action to } \\
\text { remedy unsustainable } \\
\text { use of fishery re- } \\
\text { sources may be } \\
\text { attributed to the } \\
\text { structures of the } \\
\text { social networks in a } \\
\text { Kenyan coastal } \\
\text { village. }\end{array}$ & $\begin{array}{l}\text { Implicit reference to } \\
\text { resilience: } \\
\text { Social networks as } \\
\text { factor determining } \\
\text { successful implemen- } \\
\text { tation of community } \\
\text { based co- } \\
\text { management. }\end{array}$ & $\begin{array}{l}\text { Independent: } \\
\text { Influence of networks } \\
\text { on collective action } \\
\text { towards the co- } \\
\text { management of } \\
\text { common-pool } \\
\text { resources. }\end{array}$ & $\begin{array}{l}\text { Form of coordination: } \\
\text { Networks of stake- } \\
\text { holder communication } \\
\text { as means of mobiliz- } \\
\text { ing and maintaining } \\
\text { co-management. }\end{array}$ & $\begin{array}{l}\text { Structurally explicit: } \\
\text { Complete village } \\
\text { household survey, } \\
\text { and semi-structured } \\
\text { interviews with } \\
\text { household heads in a } \\
\text { coastal village. } \\
\text { SNA: total network. }\end{array}$ & $\begin{array}{l}\text { Social relation: } \\
\text { information and } \\
\text { knowledge exchange. } \\
\text { Actors: resource } \\
\text { users in the village. } \\
\text { Scale: local / village. }\end{array}$ & $\begin{array}{l}\text { Network: community } \\
\text { management network. } \\
\text { Subgroup: occupa- } \\
\text { tional and relational } \\
\text { groups. }\end{array}$ & $\begin{array}{l}\text { Actor: occupation, } \\
\text { tribe. } \\
\text { Tie: density of inner / } \\
\text { in-between group ties. } \\
\text { Structure: centrality, } \\
\text { fragmentation (in } \\
\text { subgroups). }\end{array}$ & $\begin{array}{l}\text { Communication is mainly defined by } \\
\text { occupational groups. } \\
\text { Restricted communication between } \\
\text { groups in social networks and missing } \\
\text { incentives for brokers to act impede the } \\
\text { successful implementation of community } \\
\text { based management. }\end{array}$ \\
\hline $\begin{array}{l}\text { Crona and } \\
\text { Bodin } 2010\end{array}$ & \begin{tabular}{l|} 
Investigate if the \\
examination of power \\
relations and \\
knowledge sharing \\
networks in a Kenyan \\
coastal village can \\
explain why a com- \\
munity has not initiat- \\
ed collective action.
\end{tabular} & $\begin{array}{l}\text { Implicit reference to } \\
\text { resilience: } \\
\text { Power relations within } \\
\text { social networks as } \\
\text { factors that can } \\
\text { facilitate or prevent } \\
\text { societies from trans- } \\
\text { forming governance } \\
\text { of natural resources } \\
\text { towards resilience. }\end{array}$ & $\begin{array}{l}\text { Independent / } \\
\text { Dependent: } \\
\text { Influence of network } \\
\text { structure on collective } \\
\text { action. } \\
\text { Influence of power } \\
\text { relations on social } \\
\text { network structure. }\end{array}$ & $\begin{array}{l}\text { Form of coordination: } \\
\text { Social networks of } \\
\text { knowledge exchange } \\
\text { and power relations } \\
\text { as factors impacting } \\
\text { consensus building in } \\
\text { resource manage- } \\
\text { ment. }\end{array}$ & $\begin{array}{l}\text { Structurally explicit: } \\
\text { Complete village / } \\
\text { household survey, } \\
\text { and semi-structured } \\
\text { interviews with } \\
\text { household heads in a } \\
\text { coastal village. } \\
\text { SNA: total network. }\end{array}$ & $\begin{array}{l}\text { Social relation: } \\
\text { knowledge exchange, } \\
\text { gear lending. } \\
\text { Actors: resource } \\
\text { users in the village. } \\
\text { Scale: local / village. }\end{array}$ & $\begin{array}{l}\text { Network: knowledge, } \\
\text { and gear lending } \\
\text { network. } \\
\text { Subgroups: occupa- } \\
\text { tional and relational } \\
\text { groups. } \\
\text { Individual: opinion } \\
\text { leaders. }\end{array}$ & $\begin{array}{l}\text { Actor: gender age, } \\
\text { tribe, occupation, } \\
\text { perception of key } \\
\text { individuals. } \\
\text { Structure: degree } \\
\text { centrality. }\end{array}$ & $\begin{array}{l}\text { Opinion leaders, characterized by cen- } \\
\text { trality in knowledge and gear lending } \\
\text { networks, show little recognition and } \\
\text { willingness to change resource use, } \\
\text { because of capital invested in gear } \\
\text { equipment. } \\
\text { Opinion leaders can act as barrier to } \\
\text { change. }\end{array}$ \\
\hline $\begin{array}{l}\text { de Villiers } \\
\text { et al. } 2014\end{array}$ & \begin{tabular}{|l|} 
Determine whether \\
particular decision \\
making frameworks \\
promote adaptive \\
capacity. Explore \\
social capital amongst \\
land managers in \\
South Africa applying \\
methods of SNA.
\end{tabular} & $\begin{array}{l}\text { Explicit reference to } \\
\text { resilience: } \\
\text { Social networks } \\
\text { facilitating social } \\
\text { learning and innova- } \\
\text { tion as a key to } \\
\text { enhancing adaptive } \\
\text { capacity and resili- } \\
\text { ence of rangeland } \\
\text { management. }\end{array}$ & $\begin{array}{l}\text { Independent: } \\
\text { Impact of social } \\
\text { networks on social } \\
\text { learning and innova- } \\
\text { tion. }\end{array}$ & $\begin{array}{l}\text { Social capital: } \\
\text { Social networks as } \\
\text { structural component } \\
\text { of social capital } \\
\text { alongside cognitive } \\
\text { social capital (norms } \\
\text { and trust). }\end{array}$ & $\begin{array}{l}\text { Structurally explicit: } \\
\text { Interviews with } \\
\text { households involved } \\
\text { in land management } \\
\text { in Eastern Cape } \\
\text { Province. } \\
\text { SNA: total network } \\
\text { (constructed from } \\
\text { ego-networks). }\end{array}$ & $\begin{array}{l}\text { Social relation: seek- } \\
\text { ing advice and calling } \\
\text { in times of problems. } \\
\text { Actors: households in } \\
\text { the region. } \\
\text { Scale: regional / } \\
\text { provincial governance } \\
\text { system. }\end{array}$ & $\begin{array}{l}\text { Subgroups: groups of } \\
\text { adopters / non- } \\
\text { adopters. }\end{array}$ & $\begin{array}{l}\text { Actor: adopting } \\
\text { behavior. } \\
\text { Tie: type of ties } \\
\text { (friendship, kinship). } \\
\text { Structure: size, } \\
\text { density. }\end{array}$ & $\begin{array}{l}\text { Social learning networks in form of study } \\
\text { groups support both the structural com- } \\
\text { ponents (i.e. networks facilitating infor- } \\
\text { mation sharing and decision-making) and } \\
\text { cognitive components of social capital } \\
\text { (i.e. trust and shared values). } \\
\text { Building social networks as a foundation } \\
\text { for strong social capital is essential for } \\
\text { strengthening adaptive capacity of local } \\
\text { communities. }\end{array}$ \\
\hline
\end{tabular}




\begin{tabular}{|c|c|c|c|c|c|c|c|c|c|}
\hline $\begin{array}{l}\text { Gelcich } \\
\text { et al. } 2010 \\
\dagger\end{array}$ & $\begin{array}{l}\text { Explore social, politi- } \\
\text { cal, and ecological } \\
\text { aspects of the trans- } \\
\text { formation in Chile's } \\
\text { coastal marine re- } \\
\text { source governance, } \\
\text { from } 1980 \text { to today. }\end{array}$ & $\begin{array}{l}\text { Explicit reference to } \\
\text { resilience: } \\
\text { Social networks as a } \\
\text { vehicle to promote } \\
\text { transformation and } \\
\text { resilience building in } \\
\text { natural resource } \\
\text { governance. }\end{array}$ & $\begin{array}{l}\text { Independent: } \\
\text { Influence of social } \\
\text { networks on natural } \\
\text { resource manage- } \\
\text { ment. }\end{array}$ & $\begin{array}{l}\text { Form of coordination: } \\
\text { Social networks as } \\
\text { purposefully created } \\
\text { governance networks. }\end{array}$ & $\begin{array}{l}\text { Metaphorical: } \\
\text { Review and synthesis } \\
\text { of secondary sources } \\
\text { on the transformation } \\
\text { of a marine manage- } \\
\text { ment system in Chile. }\end{array}$ & $\begin{array}{l}\text { Social relation: } \\
\text { communication } \\
\text { Actors: resource } \\
\text { users, scientists, } \\
\text { organizations / institu- } \\
\text { tions involved in the } \\
\text { management of } \\
\text { marine resources. } \\
\text { Scale: local - national } \\
\text { governance system. } \\
\text { Temporal scale: } 1980 \\
\text { until today. }\end{array}$ & $\begin{array}{l}\text { Network: national } \\
\text { governance network. }\end{array}$ & $\begin{array}{l}\text { Tie: tie strength } \\
\text { (strong / weak), } \\
\text { bridging ties (between } \\
\text { different scales). } \\
\text { Context: facilitating } \\
\text { policies. }\end{array}$ & $\begin{array}{l}\text { The ability to network knowledge from } \\
\text { local to national level through preexisting } \\
\text { strong social networks provided critical } \\
\text { elements for the transformation of the } \\
\text { governance system towards resilience. }\end{array}$ \\
\hline $\begin{array}{l}\text { Ireland and } \\
\text { Thomalla } \\
2011\end{array}$ & $\begin{array}{l}\text { Explore the role of } \\
\text { collective action in } \\
\text { building adaptive } \\
\text { capacity in Nepal and } \\
\text { Thailand, with particu- } \\
\text { lar attention to the } \\
\text { role of social net- } \\
\text { works. }\end{array}$ & $\begin{array}{l}\text { Explicit reference to } \\
\text { resilience: } \\
\text { Social networks as } \\
\text { factor facilitating } \\
\text { community collective } \\
\text { action for resilience } \\
\text { building. }\end{array}$ & $\begin{array}{l}\text { Independent: } \\
\text { Influence of networks } \\
\text { on collective action for } \\
\text { adaptation to envi- } \\
\text { ronmental risks. }\end{array}$ & $\begin{array}{l}\text { Social capital: } \\
\text { Social networks as a } \\
\text { component of social } \\
\text { capital facilitating } \\
\text { collective action. }\end{array}$ & $\begin{array}{l}\text { Metaphorical: } \\
\text { Two case studies } \\
\text { from Nepal and } \\
\text { Thailand. } \\
\text { Semi-structured } \\
\text { interviews, vulnerabil- } \\
\text { ity analysis, and } \\
\text { participatory multi- } \\
\text { stakeholder assess- } \\
\text { ment. }\end{array}$ & $\begin{array}{l}\text { Social relation: com- } \\
\text { munication, infor- } \\
\text { mation and } \\
\text { knowledge exchange. } \\
\text { Actors: community } \\
\text { activists and collec- } \\
\text { tives involved in } \\
\text { reducing vulnerability } \\
\text { to social and envi- } \\
\text { ronmental risks. } \\
\text { Scale: (not specified) }\end{array}$ & $\begin{array}{l}\text { Individual: motivated } \\
\text { leaders. }\end{array}$ & $\begin{array}{l}\text { Actor: leadership. } \\
\text { Tie: tie strength. } \\
\text { Context: local gov- } \\
\text { ernment influence. }\end{array}$ & $\begin{array}{l}\text { Collective action is robust if it builds on } \\
\text { existing social network, and if strong and } \\
\text { motivated individuals with good social } \\
\text { networks take leadership. } \\
\text { Local government can impede collective } \\
\text { action. }\end{array}$ \\
\hline $\begin{array}{l}\text { Mannetti } \\
\text { et al. } 2015\end{array}$ & $\begin{array}{l}\text { Examine the issues of } \\
\text { social capital, leader- } \\
\text { ship, and traditional } \\
\text { knowledge in South } \\
\text { Africa and Botswana } \\
\text { and explore how they } \\
\text { contribute to collective } \\
\text { action at the commu- } \\
\text { nity level. }\end{array}$ & $\begin{array}{l}\text { Implicit reference to } \\
\text { resilience: } \\
\text { Adaptive co- } \\
\text { management systems } \\
\text { as formed of social } \\
\text { networks of actors } \\
\text { involved in imple- } \\
\text { menting rules and } \\
\text { regulations on re- } \\
\text { source use. }\end{array}$ & $\begin{array}{l}\text { Independent: } \\
\text { Influence of social } \\
\text { networks on adaptive } \\
\text { management. }\end{array}$ & $\begin{array}{l}\text { Form of coordination: } \\
\text { Networks facilitate } \\
\text { access to information } \\
\text { required for promoting } \\
\text { adaptive co-manage- } \\
\text { ment systems. }\end{array}$ & $\begin{array}{l}\text { Structurally explicit: } \\
\text { Semi-structured } \\
\text { interviews with bush- } \\
\text { men involved in } \\
\text { natural plant use from } \\
\text { six farms belonging to } \\
\text { the community. } \\
\text { SNA: total network. }\end{array}$ & $\begin{array}{l}\text { Social relation: seek- } \\
\text { ing advice and dis- } \\
\text { cussing knowledge. } \\
\text { Actors: bushmen in } \\
\text { the community. } \\
\text { Scale: local / commu- } \\
\text { nity. }\end{array}$ & $\begin{array}{l}\text { Network: knowledge } \\
\text { network, collaboration } \\
\text { network, dependency } \\
\text { network. } \\
\text { Subgroups: relational } \\
\text { groups. }\end{array}$ & $\begin{array}{l}\text { Actors: demographic } \\
\text { factors (gender, age, } \\
\text { length of residence), } \\
\text { self-perceived level of } \\
\text { knowledge. } \\
\text { Structure: density, } \\
\text { degree, dyads / triads, } \\
\text { fragmentation, group } \\
\text { cohesion. }\end{array}$ & $\begin{array}{l}\text { Gender and the length of time an individ- } \\
\text { ual has been part of the community are } \\
\text { barriers to knowledge acquisition } \\
\text { (knowledge transfer occurs primarily } \\
\text { between men). } \\
\text { Homogeneity among key players is likely } \\
\text { to reduce communities' ability to synthe- } \\
\text { size new knowledge. } \\
\text { Low levels of ties among members of the } \\
\text { network, higher fragmentation and overall } \\
\text { low network cohesion hamper the oppor- } \\
\text { tunities for collective action. }\end{array}$ \\
\hline $\begin{array}{l}\text { Marín and } \\
\text { Berkes } \\
2010 †\end{array}$ & $\begin{array}{l}\text { Assess the Chilean } \\
\text { shellfish co- } \\
\text { management system } \\
\text { from an organizational } \\
\text { network perspective } \\
\text { including networks of } \\
\text { actors, the functions } \\
\text { of these actors, and } \\
\text { fishers' perceptions } \\
\text { about Chile's co- } \\
\text { management ar- } \\
\text { rangement. }\end{array}$ & $\begin{array}{l}\text { Implicit reference to } \\
\text { resilience: } \\
\text { Co-management as } \\
\text { alternative form of } \\
\text { governance that is } \\
\text { comprised of multiple } \\
\text { and complex social } \\
\text { networks. }\end{array}$ & $\begin{array}{l}\text { Independent: } \\
\text { Influence of networks } \\
\text { on management } \\
\text { outcome. }\end{array}$ & $\begin{array}{l}\text { Form of coordination: } \\
\text { Social networks as } \\
\text { formal arrangements } \\
\text { between complex sets } \\
\text { of actors. }\end{array}$ & $\begin{array}{l}\text { Structurally explicit: } \\
\text { Focus groups, in- } \\
\text { depth interviews, and } \\
\text { questionnaire with } \\
\text { representatives of } \\
\text { fishery associations in } \\
\text { two administrative } \\
\text { regions. } \\
\text { SNA: total network } \\
\text { (two-mode). }\end{array}$ & $\begin{array}{l}\text { Social relation: facili- } \\
\text { tation, hindrance of } \\
\text { co-management. } \\
\text { Actos: small-scale } \\
\text { fisher associations, } \\
\text { public or private } \\
\text { counterparts. } \\
\text { Scale: local - national } \\
\text { governance system. }\end{array}$ & $\begin{array}{l}\text { Subgroup: functional } \\
\text { groups in hindering } \\
\text { and facilitating net- } \\
\text { works. }\end{array}$ & $\begin{array}{l}\text { Tie: positive and } \\
\text { negative ties (hinder- } \\
\text { ing / facilitating). } \\
\text { Structure: centrality. }\end{array}$ & $\begin{array}{l}\text { Studies of co-management should not } \\
\text { focus only on collaborative (or facilitat- } \\
\text { ing), but also on hindering relationships. } \\
\text { Highly centralized governance systems } \\
\text { hamper participation of grassroots } \\
\text { organizations. } \\
\text { More autonomy and ability to use existing } \\
\text { linking social capital between local } \\
\text { organizations and actors at other scales } \\
\text { would provide an opportunity to experi- } \\
\text { ment and learn. }\end{array}$ \\
\hline
\end{tabular}




\begin{tabular}{|c|c|c|c|c|c|c|c|c|c|}
\hline $\begin{array}{l}\text { Marín et al. } \\
2012 \dagger\end{array}$ & $\begin{array}{l}\text { Assess the multifunc- } \\
\text { tional relationships of } \\
\text { small-scale artisanal } \\
\text { fisher associations } \\
\text { and explore the role } \\
\text { of bridging and linking } \\
\text { social capital for co- } \\
\text { management of } \\
\text { coastal benthic } \\
\text { resource systems in } \\
\text { Chile. }\end{array}$ & $\begin{array}{l}\text { Implicit reference to } \\
\text { resilience: } \\
\text { Social networks } \\
\text { linking actors at } \\
\text { different levels pro- } \\
\text { mote performance of } \\
\text { natural resource } \\
\text { management and } \\
\text { well-being. }\end{array}$ & $\begin{array}{l}\text { Independent: } \\
\text { Influence of social } \\
\text { networks on econom- } \\
\text { ic performance of } \\
\text { fisher associations. }\end{array}$ & $\begin{array}{l}\text { Social capital: } \\
\text { Investment in social } \\
\text { relations pay-back in } \\
\text { form of enhanced } \\
\text { opportunities and } \\
\text { capacities. }\end{array}$ & $\begin{array}{l}\text { Structurally explicit: } \\
\text { Semi-structured } \\
\text { interviews with repre- } \\
\text { sentatives of fisher } \\
\text { associations in two } \\
\text { administrative re- } \\
\text { gions. } \\
\text { SNA: ego-network. }\end{array}$ & $\begin{array}{l}\text { Social relation: } \\
\text { facilitation and hin- } \\
\text { drance of co- } \\
\text { management. } \\
\text { Actors: small-scale } \\
\text { fisher associations, } \\
\text { public or private } \\
\text { counterparts. } \\
\text { Scale: local - national } \\
\text { governance system- }\end{array}$ & $\begin{array}{l}\text { Subgroups: social } \\
\text { capital groups. }\end{array}$ & $\begin{array}{l}\text { Actor: co-manage- } \\
\text { ment performance } \\
\text { Tie: bridging ties } \\
\text { (between groups at } \\
\text { the same level), } \\
\text { linking ties (between } \\
\text { groups at different } \\
\text { levels). } \\
\text { Structure: centrality }\end{array}$ & $\begin{array}{l}\text { Best performing fisher associations are } \\
\text { those with higher levels of linking and } \\
\text { bridging social capital. } \\
\text { Policy regulations and instruments } \\
\text { should promote vertical and horizontal } \\
\text { relationships. }\end{array}$ \\
\hline $\begin{array}{l}\text { Marin et al. } \\
2015 \dagger\end{array}$ & $\begin{array}{l}\text { Investigate if and how } \\
\text { social capital - in } \\
\text { combination with the } \\
\text { levels of damage and } \\
\text { geographic isolation - } \\
\text { determines fishing } \\
\text { organizations' ability } \\
\text { to recover and inno- } \\
\text { vate in response to a } \\
\text { tsunami disaster. }\end{array}$ & $\begin{array}{l}\text { Explicit reference to } \\
\text { resilience: } \\
\text { Social networks are } \\
\text { an internal factor of } \\
\text { social-ecological } \\
\text { systems. Social } \\
\text { networks promote } \\
\text { capacity to respond to } \\
\text { risks and adapt to } \\
\text { change and hence- } \\
\text { in combination with } \\
\text { external factors - } \\
\text { determine community } \\
\text { resilience. }\end{array}$ & $\begin{array}{l}\text { Independent: } \\
\text { Impact of social } \\
\text { capital / linking ties on } \\
\text { the recovery trajecto- } \\
\text { res of fishing com- } \\
\text { munities }\end{array}$ & $\begin{array}{l}\text { Form of coordination / } \\
\text { Social capital: } \\
\text { Social networks as } \\
\text { purposeful developed } \\
\text { networks for co- } \\
\text { management of } \\
\text { natural resources. } \\
\text { Social capital as } \\
\text { resources embedded } \\
\text { in social structure / as } \\
\text { linking ties providing } \\
\text { resources and sup- } \\
\text { port from other plac- } \\
\text { es. }\end{array}$ & $\begin{array}{l}\text { Structurally explicit: } \\
\text { Panel study including } \\
\text { semi-structured } \\
\text { interviews with repre- } \\
\text { sentatives, fisher } \\
\text { associations, and } \\
\text { regional officials in a } \\
\text { coastal region before } \\
\text { and after a tsunami. } \\
\text { SNA: ego-network. }\end{array}$ & $\begin{array}{l}\text { Social relation: facili- } \\
\text { tating relationships for } \\
\text { the development of } \\
\text { collaborative man- } \\
\text { agement. } \\
\text { Actors: fishery author- } \\
\text { ities, researchers and } \\
\text { consultants, buyers } \\
\text { and traders. } \\
\text { Scale: local - national } \\
\text { governance system } \\
\text { Temporal: } 2008 \text { and } \\
2013 \text {. }\end{array}$ & $\begin{array}{l}\text { Subgroups: groups of } \\
\text { fisher organizations } \\
\text { with different social } \\
\text { capital, external } \\
\text { factors, and trajecto- } \\
\text { ries. }\end{array}$ & $\begin{array}{l}\text { Ties: linking ties } \\
\text { (cross-scale ties to } \\
\text { external actors). } \\
\text { Structure: centrality }\end{array}$ & $\begin{array}{l}\text { Higher levels of linking social capital are } \\
\text { correlated with more positive post- } \\
\text { tsunami trajectories. } \\
\text { Social networks developed for co- } \\
\text { management can facilitate disaster } \\
\text { recovery. } \\
\text { However, social capital changes over } \\
\text { time and post disaster trajectories are } \\
\text { also influenced by external factors } \\
\text { (amount of damage and geographical } \\
\text { isolation). This fact implies that relying } \\
\text { only on social relations is a limited } \\
\text { strategy for community recovery. }\end{array}$ \\
\hline $\begin{array}{l}\text { Moeliono } \\
\text { et al. } 2014\end{array}$ & \begin{tabular}{|l|} 
Analyze patterns of \\
information exchange \\
related to REDD+ \\
policy networks in \\
Indonesia. Help to \\
identify potential \\
barriers to the trans- \\
formational change \\
needed to implement \\
REDD+.
\end{tabular} & $\begin{array}{l}\text { Implicit reference to } \\
\text { resilience: } \\
\text { Adaptive manage- } \\
\text { ment of social- } \\
\text { ecological systems } \\
\text { requires networks } \\
\text { fostering the combina- } \\
\text { tion of local } \\
\text { knowledge, cross- } \\
\text { scale coordination, } \\
\text { and social learning. }\end{array}$ & $\begin{array}{l}\text { Independent: } \\
\text { Influence of network } \\
\text { structure on infor- } \\
\text { mation exchange and } \\
\text { governance outcome. }\end{array}$ & $\begin{array}{l}\text { Form of coordination: } \\
\text { Governance networks } \\
\text { as purposefully } \\
\text { created networks of } \\
\text { inter-organizational } \\
\text { linkages. }\end{array}$ & $\begin{array}{l}\text { Structurally explicit: } \\
\text { Semi-structured } \\
\text { interviews with repre- } \\
\text { sentatives of organi- } \\
\text { zations involved in } \\
\text { REDD+ Indonesia. } \\
\text { SNA: total network. }\end{array}$ & $\begin{array}{l}\text { Social relation: regu- } \\
\text { lar exchange of } \\
\text { information. } \\
\text { Actors: organizations } \\
\text { from academic, } \\
\text { private, and public } \\
\text { sector. } \\
\text { Scale: national - } \\
\text { international govern- } \\
\text { ance system. }\end{array}$ & $\begin{array}{l}\text { Network: governance } \\
\text { network. } \\
\text { Subgroups: relational } \\
\text { groups. } \\
\text { Individual: brokers. }\end{array}$ & $\begin{array}{l}\text { Actor: number of } \\
\text { employees, head- } \\
\text { quarter locations, } \\
\text { membership in organ- } \\
\text { izations. } \\
\text { Structure: centrality, } \\
\text { subgroup fragmenta- } \\
\text { tion. }\end{array}$ & $\begin{array}{l}\text { Homophily and power generate a net- } \\
\text { work that lacks the integration between } \\
\text { diverse groups. } \\
\text { Power asymmetries can hinder effective } \\
\text { and inclusive governance. } \\
\text { Brokers able to connect different clusters } \\
\text { of information seeking will be crucial for } \\
\text { effective and inclusive management. }\end{array}$ \\
\hline $\begin{array}{l}\text { Nuno et al. } \\
2014\end{array}$ & $\begin{array}{l}\text { Analyze the multiple } \\
\text { roles played by } \\
\text { different institutions in } \\
\text { the management } \\
\text { system of the Seren- } \\
\text { geti and describe the } \\
\text { interactions between } \\
\text { different actor types. }\end{array}$ & $\begin{array}{l}\text { Explicit reference to } \\
\text { resilience: } \\
\text { Social networks as a } \\
\text { means to characterize } \\
\text { collaborations and } \\
\text { social relationships } \\
\text { facilitating conserva- } \\
\text { tion and promoting } \\
\text { resilience of govern- } \\
\text { ance. }\end{array}$ & $\begin{array}{l}\text { Independent: } \\
\text { Influence of social } \\
\text { networks on man- } \\
\text { agement outcome. }\end{array}$ & $\begin{array}{l}\text { Form of coordination: } \\
\text { Management systems } \\
\text { as networks of organ- } \\
\text { izations involved in } \\
\text { resource manage- } \\
\text { ment. }\end{array}$ & $\begin{array}{l}\text { Structurally explicit: } \\
\text { Scenario building, } \\
\text { institutional analysis, } \\
\text { and semi-structured } \\
\text { interviews with repre- } \\
\text { sentatives of organi- } \\
\text { zations responsible } \\
\text { for the regulation of } \\
\text { resource use in the } \\
\text { Serengeti. } \\
\text { SNA: total network. }\end{array}$ & $\begin{array}{l}\text { Social relation: advice } \\
\text { and support aiming to } \\
\text { influence policy or } \\
\text { implementation } \\
\text { interventions. } \\
\text { Actors: resource } \\
\text { management organi- } \\
\text { zations. } \\
\text { Scale: local - regional } \\
\text { governance system. }\end{array}$ & $\begin{array}{l}\text { Network: governance } \\
\text { network (including } \\
\text { policy and implemen- } \\
\text { tation network). } \\
\text { Individual: brokers / } \\
\text { bridging actors. }\end{array}$ & $\begin{array}{l}\text { Tie: frequency } \\
\text { Structure: edge } \\
\text { connectivity, density, } \\
\text { mean geodesic } \\
\text { distance, centrality. }\end{array}$ & $\begin{array}{l}\text { Management networks center on very } \\
\text { few individuals. These individuals are } \\
\text { important in bridging across conservation } \\
\text { arenas and therefore are able to poten- } \\
\text { tially affect the resilience of governance } \\
\text { structures. } \\
\text { Understanding the complexity of behavior } \\
\text { of key actors within management institu- } \\
\text { tions is important for implementation of } \\
\text { sustainable management. }\end{array}$ \\
\hline
\end{tabular}




\begin{tabular}{|c|c|c|c|c|c|c|c|c|c|}
\hline $\begin{array}{l}\text { Pietri et al. } \\
2015\end{array}$ & $\begin{array}{l}\text { Examine the major } \\
\text { patterns of infor- } \\
\text { mation exchange } \\
\text { among individuals of } \\
\text { the Coral Triangle } \\
\text { Initiative and evaluate } \\
\text { impacts on infor- } \\
\text { mation sharing. } \\
\text { Consider implications } \\
\text { for strengthening } \\
\text { network sustainability, } \\
\text { capacity building, and } \\
\text { learning. }\end{array}$ & $\begin{array}{l}\text { Explicit reference to } \\
\text { resilience: } \\
\text { Learning networks are } \\
\text { building on social } \\
\text { capital which can help } \\
\text { fostering resilience } \\
\text { and achieving social } \\
\text { and environmental } \\
\text { goals. }\end{array}$ & $\begin{array}{l}\text { Independent: } \\
\text { Influence of social } \\
\text { networks on capacity } \\
\text { building and learning. }\end{array}$ & $\begin{array}{l}\text { Form of coordination / } \\
\text { Social capital: } \\
\text { Governance networks } \\
\text { as purposefully } \\
\text { designed networks for } \\
\text { promoting social } \\
\text { capital through social } \\
\text { learning and capacity } \\
\text { building. }\end{array}$ & $\begin{array}{l}\text { Structurally explicit: } \\
\text { Qualitative key in- } \\
\text { formant interviews } \\
\text { and standardized } \\
\text { (electronic) survey } \\
\text { with representatives } \\
\text { of organizations } \\
\text { involved in the Coral } \\
\text { Triangle Initiative. } \\
\text { SNA: total network. }\end{array}$ & $\begin{array}{l}\text { Social relation: seek- } \\
\text { ing information with } \\
\text { regard to coral reef } \\
\text { management issues. } \\
\text { Actos: organizations } \\
\text { and partner countries } \\
\text { participating in marine } \\
\text { protected area man- } \\
\text { agement. } \\
\text { Scale: national - } \\
\text { international govern- } \\
\text { ance system. }\end{array}$ & $\begin{array}{l}\text { Network: governance } \\
\text { network. } \\
\text { Individual: coordina- } \\
\text { tors. }\end{array}$ & $\begin{array}{l}\text { Actor: organizational } \\
\text { affiliation, nationality, } \\
\text { brokerage types. } \\
\text { Ties: scores, ratio of } \\
\text { internal / external } \\
\text { links. } \\
\text { Structure: density, } \\
\text { centralization, frag- } \\
\text { mentation. }\end{array}$ & $\begin{array}{l}\text { A decentralized network structure with } \\
\text { redundancy of ties indicates potential } \\
\text { resilience to changes in leadership and } \\
\text { membership. } \\
\text { Conservation learning networks have the } \\
\text { ability to bridge cultural divides and } \\
\text { promote social learning. } \\
\text { A strong coordinator and continuing } \\
\text { efforts to support information sharing and } \\
\text { learning are crucial to the network's } \\
\text { strength and sustainability. }\end{array}$ \\
\hline $\begin{array}{l}\text { Ramirez- } \\
\text { Sanchez } \\
\text { and } \\
\text { Pinkerton } \\
2009+\end{array}$ & $\begin{array}{l}\text { Examine the effect of } \\
\text { resource scarcity on } \\
\text { the bonding, bridging, } \\
\text { and linking social- } \\
\text { capital patterns of } \\
\text { fishers' information- } \\
\text { sharing networks in } \\
\text { coastal communities } \\
\text { in Chile. }\end{array}$ & $\begin{array}{l}\text { Explicit reference to } \\
\text { resilience: } \\
\text { Social capital pat- } \\
\text { terned by social } \\
\text { networks of trust can } \\
\text { enable or constrain } \\
\text { collaborative ar- } \\
\text { rangements and } \\
\text { collective action and } \\
\text { therefore impact the } \\
\text { resilience of social- } \\
\text { ecological systems } \\
\text { governance. }\end{array}$ & $\begin{array}{l}\text { Dependent: } \\
\text { Influence of resource } \\
\text { scarcity on social } \\
\text { networks and the } \\
\text { production and distri- } \\
\text { bution of social capital }\end{array}$ & $\begin{array}{l}\text { Social capital: } \\
\text { Social relations as } \\
\text { means of supporting } \\
\text { fishers' adaptive } \\
\text { responses to resource } \\
\text { fluctuations, external } \\
\text { shocks, and other } \\
\text { uncertainties. }\end{array}$ & $\begin{array}{l}\text { Structurally explicit: } \\
\text { Survey questionnaire } \\
\text { and key informant } \\
\text { interviews in six } \\
\text { communities in the } \\
\text { municipality. } \\
\text { SNA: total network. }\end{array}$ & $\begin{array}{l}\text { Social relation: trust- } \\
\text { worthy information on } \\
\text { the state and location } \\
\text { of fish. } \\
\text { Actors: fishers in the } \\
\text { community, fishers in } \\
\text { other communities. } \\
\text { Scale: local / commu- } \\
\text { nity + linkages be- } \\
\text { tween communities. }\end{array}$ & $\begin{array}{l}\text { Subgroup: social } \\
\text { capital groups. }\end{array}$ & $\begin{array}{l}\text { Tie: bonding ties } \\
\text { (within a group) } \\
\text { bridging ties (between } \\
\text { groups in the same } \\
\text { community), linking } \\
\text { ties (between com- } \\
\text { munities). } \\
\text { Structure: fragmenta- } \\
\text { tion, subgroups. } \\
\text { Context: resource } \\
\text { scarcity. }\end{array}$ & $\begin{array}{l}\text { Social networks are activated and deac- } \\
\text { tivated during transitions in fish abun- } \\
\text { dance. } \\
\text { Presence of linking ties as indicator of } \\
\text { the extent to which fishers adopt geo- } \\
\text { graphic mobility as a coping strategy to } \\
\text { deal with resource scarcity. } \\
\text { Although fishers have adaptive capacity } \\
\text { for dealing with fish fluctuations, they } \\
\text { have little or no proactive resilience to } \\
\text { address the decline of resources. }\end{array}$ \\
\hline $\begin{array}{l}\text { Rico } \\
\text { García- } \\
\text { Amado } \\
\text { et al. } 2012\end{array}$ & $\begin{array}{l}\text { Understand social } \\
\text { capital, decision- } \\
\text { making, and collective } \\
\text { action in forest-based } \\
\text { common pool re- } \\
\text { source management } \\
\text { in Chiapas, Mexico. }\end{array}$ & $\begin{array}{l}\text { Explicit reference to } \\
\text { resilience } \\
\text { Social networks of } \\
\text { trust, reciprocal } \\
\text { exchanges, norms, } \\
\text { and sanctions are } \\
\text { positively related to } \\
\text { collective action } \\
\text { required for resilient } \\
\text { common pool govern- } \\
\text { ance. }\end{array}$ & $\begin{array}{l}\text { Independent / } \\
\text { Dependent: } \\
\text { Impact of social } \\
\text { networks on produc- } \\
\text { tive activities and } \\
\text { conservation of forest } \\
\text { resources. } \\
\text { Impact of market } \\
\text { requirements on } \\
\text { social network struc- } \\
\text { ture. }\end{array}$ & $\begin{array}{l}\text { Social capital / } \\
\text { Form of coordination } \\
\text { Norms and social } \\
\text { networks as factors of } \\
\text { social capital and } \\
\text { collective action for } \\
\text { resource manage- } \\
\text { ment. }\end{array}$ & $\begin{array}{l}\text { Structurally explicit: } \\
\text { Observations and } \\
\text { semi-structured } \\
\text { household interviews } \\
\text { with all household } \\
\text { heads in the local } \\
\text { administrative unit. } \\
\text { SNA: total network. }\end{array}$ & $\begin{array}{l}\text { Social relation: work- } \\
\text { related demand of } \\
\text { assistance. } \\
\text { Actors: households } \\
\text { and public or private } \\
\text { actors. } \\
\text { Scale: local / adminis- } \\
\text { trative unit + external } \\
\text { linkages. }\end{array}$ & $\begin{array}{l}\text { Network: manage- } \\
\text { ment networks (i.e. } \\
\text { palm / coffee). } \\
\text { Subgroups: crop / } \\
\text { producer groups. }\end{array}$ & $\begin{array}{l}\text { Actor: tenure, cash } \\
\text { income, group affilia- } \\
\text { tion. } \\
\text { Structure: centrality, } \\
\text { cluster and sub- } \\
\text { groups, hierarchy. } \\
\text { Context: market } \\
\text { changes and re- } \\
\text { quirements. }\end{array}$ & $\begin{array}{l}\text { Market requirements shape networks } \\
\text { Organic coffee commercialization is the } \\
\text { main source of bridging ties that have } \\
\text { resulted in more connectivity and resili- } \\
\text { ence. } \\
\text { Despite power asymmetries and internal } \\
\text { conflicts, the local network facilitates an } \\
\text { effective management of common pool } \\
\text { resources. } \\
\text { Institution-building is required, because } \\
\text { highly centralized networks may not be } \\
\text { appropriate for governing social- } \\
\text { ecological systems in the long term. }\end{array}$ \\
\hline $\begin{array}{l}\text { Sanginga } \\
\text { et al. } 2007\end{array}$ & $\begin{array}{l}\text { Examine the role, } \\
\text { strengths, and limits } \\
\text { of social capital in } \\
\text { managing conflicts } \\
\text { over the use and } \\
\text { management of } \\
\text { natural resources in } \\
\text { Uganda. }\end{array}$ & $\begin{array}{l}\text { Implicit reference to } \\
\text { resilience: } \\
\text { Social networks } \\
\text { facilitate coordination } \\
\text { and cooperation for } \\
\text { mutually beneficial } \\
\text { collective action and } \\
\text { help to manage }\end{array}$ & $\begin{array}{l}\text { Independent: } \\
\text { Influence of social } \\
\text { networks on resource } \\
\text { management and } \\
\text { conflict resolution. }\end{array}$ & $\begin{array}{l}\text { Social capital: } \\
\text { Social networks as } \\
\text { assets upon which } \\
\text { people rely to manage } \\
\text { natural resources and } \\
\text { resolve conflicts. }\end{array}$ & $\begin{array}{l}\text { Metaphorical: } \\
\text { Interviews with farm- } \\
\text { ers in } 16 \text { villages in } \\
\text { one district. }\end{array}$ & $\begin{array}{l}\text { Social relation: link- } \\
\text { ages, membership in } \\
\text { formal / informal } \\
\text { associations (not } \\
\text { specified). } \\
\text { Actors: farmers in the } \\
\text { village, farmers from } \\
\text { other villages. }\end{array}$ & (not specified) & $\begin{array}{l}\text { Tie: bonding ties } \\
\text { (between members of } \\
\text { the same group), } \\
\text { bridging ties (between } \\
\text { different groups), and } \\
\text { linking ties (connect- } \\
\text { ing actors of different } \\
\text { status). }\end{array}$ & $\begin{array}{l}\text { Farmers use several social capital } \\
\text { mechanisms for managing conflicts. } \\
\text { A combination of social, economic, and } \\
\text { political factors has undermined the } \\
\text { ability of local bonding mechanisms to } \\
\text { manage conflicts. } \\
\text { Bridging capital has a relatively higher }\end{array}$ \\
\hline
\end{tabular}




\begin{tabular}{|c|c|c|c|c|c|c|c|c|c|}
\hline & & $\begin{array}{l}\text { natural resources and } \\
\text { to resolve conflicts. }\end{array}$ & & & & $\begin{array}{l}\text { Scale: local / commu- } \\
\text { nity + linkages be- } \\
\text { tween communities. }\end{array}$ & & $\begin{array}{l}\text { Context: social, } \\
\text { economic, and politi- } \\
\text { cal factors. }\end{array}$ & capacity to resolve conflicts. \\
\hline $\begin{array}{l}\text { Stein et al. } \\
2011\end{array}$ & $\begin{array}{l}\text { Empirical mapping of } \\
\text { collaborative social } \\
\text { networks between } \\
\text { actors that either } \\
\text { directly or indirectly } \\
\text { influence water flows } \\
\text { in the Mkindo catch- } \\
\text { ment in Tanzania. }\end{array}$ & $\begin{array}{l}\text { Implicit reference to } \\
\text { resilience: } \\
\text { Social networks } \\
\text { matter for the adap- } \\
\text { tive co-management } \\
\text { of natural resources. }\end{array}$ & $\begin{array}{l}\text { Independent: } \\
\text { Influence of social } \\
\text { networks on govern- } \\
\text { ance outcome. }\end{array}$ & $\begin{array}{l}\text { Form of coordination: } \\
\text { Governance networks } \\
\text { consisting of formal } \\
\text { and informal relations } \\
\text { between political, } \\
\text { social, and economic } \\
\text { organizations and } \\
\text { institutions. }\end{array}$ & \begin{tabular}{|l|l} 
Structurally explicit: & \\
Questionnaire and & \\
semi-structured & \\
interviews with stake- & \\
holders in the catch- & \\
ment area (including & \\
leaders in four villag- & \\
es). & \\
SNA: total network. &
\end{tabular} & $\begin{array}{l}\text { Social relation: fund- } \\
\text { ing, information and } \\
\text { knowledge exchange, } \\
\text { collaboration. } \\
\text { Actors: organizations } \\
\text { and institutions } \\
\text { involved in water } \\
\text { management. } \\
\text { Scale: local - regional } \\
\text { governance system. }\end{array}$ & $\begin{array}{l}\text { Network: governance } \\
\text { network. } \\
\text { Individual: influential } \\
\text { actors. }\end{array}$ & $\begin{array}{l}\text { Structure: density, } \\
\text { centralization, group } \\
\text { analysis. }\end{array}$ & $\begin{array}{l}\text { Village leaders play a crucial role in } \\
\text { linking otherwise disconnected actors but } \\
\text { are not integrated in the management } \\
\text { system. } \\
\text { Instead of imposing top-down institutional } \\
\text { arrangements, it is more promising to } \\
\text { build on existing social structures. }\end{array}$ \\
\hline $\begin{array}{l}\text { Sundstrom } \\
\text { et al. } 2012\end{array}$ & \begin{tabular}{|l|} 
Examine how ranch \\
privatization and \\
settlement of individ- \\
ual Maasai house- \\
holds have affected \\
traditional livestock \\
herding and social \\
capital mechanisms of \\
Maasai livestock \\
herders in Kenya.
\end{tabular} & $\begin{array}{l}\text { Implicit reference to } \\
\text { resilience: } \\
\text { In the context of } \\
\text { insecure tenure rights } \\
\text { over land and natural } \\
\text { resources, trusted } \\
\text { long-term social } \\
\text { networks can enforce } \\
\text { property rights and } \\
\text { sustain natural re- } \\
\text { sources. }\end{array}$ & $\begin{array}{l}\text { Independent / } \\
\text { Dependent: } \\
\text { Social networks as a } \\
\text { mechanism to ensure } \\
\text { access to natural } \\
\text { resources. } \\
\text { Impact of rangeland } \\
\text { privatization on social } \\
\text { networks. }\end{array}$ & $\begin{array}{l}\text { Social capital: } \\
\text { Social ties among } \\
\text { networks members } \\
\text { generating collective } \\
\text { well-being. }\end{array}$ & $\begin{array}{l}\text { Metaphorical: } \\
\text { Narrative interview, } \\
\text { group discussions in } \\
\text { the area of a former } \\
\text { ranch. }\end{array}$ & $\begin{array}{l}\text { Social relations: } \\
\text { customary relations, } \\
\text { reciprocal use of land } \\
\text { and resource. } \\
\text { Actors: Masaai com- } \\
\text { munity members. } \\
\text { Scale: local / village + } \\
\text { external linkages. }\end{array}$ & $\begin{array}{l}\text { Individual: particular } \\
\text { herders. }\end{array}$ & $\begin{array}{l}\text { Ties: bonding ties } \\
\text { (among kin and } \\
\text { friends), bridging ties } \\
\text { (to actors outside the } \\
\text { community). } \\
\text { Context: rangeland } \\
\text { privatization. }\end{array}$ & $\begin{array}{l}\text { Land subdivision has altered customary } \\
\text { social networks and resource govern- } \\
\text { ance. } \\
\text { Individuals can generate new social } \\
\text { capital mechanisms based on a combina- } \\
\text { tion of bonding and bridging ties. } \\
\text { Bridging ties reaching outside the com- } \\
\text { munity can help to shape the transition to } \\
\text { commercial livestock practices and take } \\
\text { advantage of development opportunities. }\end{array}$ \\
\hline $\begin{array}{l}\text { Tompkins } \\
\text { et al. } 2002\end{array}$ & $\begin{array}{l}\text { Investigate the role of } \\
\text { institutional networks } \\
\text { for integrated and } \\
\text { inclusive coastal-zone } \\
\text { management in } \\
\text { Trinidad and Tobago. }\end{array}$ & $\begin{array}{l}\text { Implicit reference to } \\
\text { resilience: } \\
\text { Social networks and } \\
\text { the ability of its social } \\
\text { actors to combine } \\
\text { information and } \\
\text { resources outside the } \\
\text { local sphere of institu- } \\
\text { tions are important } \\
\text { means by which } \\
\text { integrated and inclu- } \\
\text { sive management are } \\
\text { maintained. }\end{array}$ & $\begin{array}{l}\text { Independent / } \\
\text { Dependent: } \\
\text { Influence of social } \\
\text { networks on inclusive } \\
\text { resource manage- } \\
\text { ment. } \\
\text { Influence of legislation } \\
\text { and regulation on } \\
\text { social networks. }\end{array}$ & $\begin{array}{l}\text { Form of coordination: } \\
\text { Governance as } \\
\text { facilitated by networks } \\
\text { of institutions at } \\
\text { various scales: }\end{array}$ & \begin{tabular}{l|l} 
Metaphorical: & \\
Semi-structured & \\
interviews and partici- \\
patory workshops with \\
representatives of \\
coastal resource \\
management institu- \\
tions.
\end{tabular} & $\begin{array}{l}\text { Social relation: institu- } \\
\text { tional relations relied } \\
\text { on for the realization } \\
\text { of essential interests. } \\
\text { Actors: institutions } \\
\text { involved in the man- } \\
\text { agement of coastal } \\
\text { resources. } \\
\text { Scale: local - interna- } \\
\text { tional governance } \\
\text { system. }\end{array}$ & $\begin{array}{l}\text { Network: spaces of } \\
\text { dependency (between } \\
\text { localized organiza- } \\
\text { tions), spaces of } \\
\text { engagement (be- } \\
\text { tween local stake- } \\
\text { holders and external } \\
\text { interests). }\end{array}$ & $\begin{array}{l}\text { Context: institutional } \\
\text { setup / legislation and } \\
\text { regulations. }\end{array}$ & $\begin{array}{l}\text { Cross-scale networks may permit an } \\
\text { institutional shift towards more integrated } \\
\text { and inclusive approaches. } \\
\text { There are winners and losers in any } \\
\text { strengthening of networks for the co- } \\
\text { management of resources. Thus there is } \\
\text { a need to understand the institutional } \\
\text { form of networks facilitating inclusive } \\
\text { decision making at various scales. }\end{array}$ \\
\hline
\end{tabular}

† We included studies from Chile, despite its high-income status, in order to take account of representative studies. 
A1.2: Strand ii: Agricultural innovation

\begin{tabular}{|c|c|c|c|c|c|c|c|c|c|}
\hline \multirow[t]{3}{*}{ Authors } & \multirow[t]{3}{*}{ Research interest } & \multicolumn{3}{|c|}{ Conceptualization } & \multicolumn{4}{|c|}{ Operationalization } & \multirow[t]{3}{*}{ Key findings } \\
\hline & & \multirow{2}{*}{$\begin{array}{l}\text { Conceptual } \\
\text { framing }\end{array}$} & \multirow{2}{*}{$\begin{array}{l}\text { Network } \\
\text { variable }\end{array}$} & \multirow{2}{*}{$\begin{array}{l}\text { Network } \\
\text { narrative }\end{array}$} & \multirow[t]{2}{*}{ Network approach } & \multirow{2}{*}{$\begin{array}{l}\text { Network } \\
\text { definition }\end{array}$} & \multicolumn{2}{|c|}{ Network analysis } & \\
\hline & & & & & & & Network level & Network characteristics & \\
\hline Arora 2012 & $\begin{array}{l}\text { Study farmers' partic- } \\
\text { ipation in knowledge } \\
\text { circulation in the } \\
\text { context of a participa- } \\
\text { tory project on agro- } \\
\text { ecological methods in } \\
\text { rural India. }\end{array}$ & $\begin{array}{l}\text { Implicit reference to } \\
\text { resilience: } \\
\text { Agricultural innovation } \\
\text { as a way out of } \\
\text { indebtedness and } \\
\text { resource depletion } \\
\text { necessitates dyadic } \\
\text { user-producer interac- } \\
\text { tions which are } \\
\text { embedded in wider } \\
\text { knowledge networks } \\
\text { between heterogene- } \\
\text { ous actors. }\end{array}$ & $\begin{array}{l}\text { Independent / } \\
\text { Dependent: } \\
\text { Impact of social } \\
\text { networks on adoption } \\
\text { of agro-ecological } \\
\text { methods. } \\
\text { Influence of institu- } \\
\text { tions on network } \\
\text { structure. }\end{array}$ & $\begin{array}{l}\text { Pipe: } \\
\text { Knowledge networks } \\
\text { constituted by circuits } \\
\text { of knowledge ex- } \\
\text { change. }\end{array}$ & $\begin{array}{l}\text { Structurally explicit: } \\
\text { Complete village } \\
\text { survey in a rural } \\
\text { community. } \\
\text { SNA: total network. }\end{array}$ & $\begin{array}{l}\text { Social relation: } \\
\text { problem solving } \\
\text { knowledge in the face } \\
\text { of agricultural pest } \\
\text { attacks. } \\
\text { Actors: farmers and } \\
\text { external actors (ex- } \\
\text { perts, NGOs, input } \\
\text { supplier). } \\
\text { Scale local / village + } \\
\text { external linkages. }\end{array}$ & $\begin{array}{l}\text { Subgroup: learning } \\
\text { circles. }\end{array}$ & $\begin{array}{l}\text { Actor: caste, occupa- } \\
\text { tional group (farmer, } \\
\text { NGO, private sector), } \\
\text { experience of pest } \\
\text { attack, adoption of } \\
\text { sustainable practices. } \\
\text { Tie: number of links. } \\
\text { Structure: centrality, } \\
\text { analysis of closed } \\
\text { circles. } \\
\text { Context: institutions / } \\
\text { political influence. }\end{array}$ & $\begin{array}{l}\text { Resource persons at the local level act } \\
\text { as brokers between the development } \\
\text { agency and its beneficiaries. } \\
\text { Few farmers involved in knowledge } \\
\text { circuits are "elite" farmers in the village } \\
\text { who derive their influence from a number } \\
\text { of relational and experiential factors that } \\
\text { are hinged on formal and informal institu- } \\
\text { tions. } \\
\text { Knowledge is produced and interpreted } \\
\text { within a set of unequal power relations. }\end{array}$ \\
\hline $\begin{array}{l}\text { Bandiera } \\
\text { and Rasul } \\
2006\end{array}$ & $\begin{array}{l}\text { Explore the role of } \\
\text { family and friendship } \\
\text { networks on the } \\
\text { adoption of a new } \\
\text { crop in Mozambique. }\end{array}$ & $\begin{array}{l}\text { Implicit reference to } \\
\text { resilience: } \\
\text { Adoption of new } \\
\text { agricultural technolo- } \\
\text { gies as an important } \\
\text { route out of poverty. } \\
\text { Farmers learn how to } \\
\text { cultivate a new crop } \\
\text { from the choices of } \\
\text { others tied together in } \\
\text { strong social net- } \\
\text { works. }\end{array}$ & $\begin{array}{l}\text { Independent: } \\
\text { Influence of social } \\
\text { networks on adoption } \\
\text { behavior. }\end{array}$ & $\begin{array}{l}\text { Pipe: } \\
\text { Social networks as } \\
\text { conduit for the diffu- } \\
\text { sion of information } \\
\text { about new crops. }\end{array}$ & \begin{tabular}{|l|} 
Descriptive: \\
Household survey, \\
key informant inter- \\
views in nine villages. \\
Econometric modeling \\
/ analysis.
\end{tabular} & $\begin{array}{l}\text { Social relation: } \\
\text { information seeking } \\
\text { on sunflower cultiva- } \\
\text { tion. } \\
\text { Actors: farmers in the } \\
\text { village, friends, and } \\
\text { kin in other villages. } \\
\text { Scale: local / village + } \\
\text { linkages between } \\
\text { villages. }\end{array}$ & Individual: farmers. & $\begin{array}{l}\text { Actor: adopting } \\
\text { status, relational } \\
\text { group (kin, family } \\
\text { neighbor), labor and } \\
\text { agricultural tools, } \\
\text { exposure to risk (food } \\
\text { insecurity), cashew } \\
\text { cultivation, participa- } \\
\text { tion in NGO activities, } \\
\text { demographic data, } \\
\text { migration status. } \\
\text { Structure: network } \\
\text { size. }\end{array}$ & $\begin{array}{l}\text { The probability that a farmer adopts a } \\
\text { new technology is increasing with the } \\
\text { number of adopters in his network when } \\
\text { there are few, and decreasing when } \\
\text { there are many informed farmers. } \\
\text { Adoption decisions are more correlated } \\
\text { within family and friends than religion- } \\
\text { based networks, and uncorrelated among } \\
\text { individuals of different religions. }\end{array}$ \\
\hline Butt 2015 & $\begin{array}{l}\text { Examine the political, } \\
\text { economic, ecological, } \\
\text { and socio-spatial } \\
\text { contexts and the } \\
\text { relevance of mobile } \\
\text { phone use among } \\
\text { pastoralists in Kenya. }\end{array}$ & $\begin{array}{l}\text { Implicit reference to } \\
\text { resilience: } \\
\text { Technology as main } \\
\text { driver of a social } \\
\text { group's ability to } \\
\text { adapt to rapidly } \\
\text { changing social, } \\
\text { political, economic, } \\
\text { and environmental } \\
\text { conditions. }\end{array}$ & $\begin{array}{l}\text { Dependent: } \\
\text { Impact of mobile } \\
\text { phone use on com- } \\
\text { munication networks } \\
\text { related to herding. }\end{array}$ & $\begin{array}{l}\text { Pipe: } \\
\text { Social networks as } \\
\text { conduit for the ex- } \\
\text { change of information. }\end{array}$ & $\begin{array}{l}\text { Metaphorical: } \\
\text { Qualitative ethno- } \\
\text { graphic research in } \\
\text { the study site. }\end{array}$ & $\begin{array}{l}\text { Social relation: } \\
\text { enquiring information } \\
\text { about herding related } \\
\text { issues. } \\
\text { Actors: herders. } \\
\text { Scale: local / study } \\
\text { site }\end{array}$ & Individual: herders. & $\begin{array}{l}\text { Tie: kinship, clan } \\
\text { membership. }\end{array}$ & $\begin{array}{l}\text { Information sharing among pastoralists } \\
\text { using mobile phones transcends social } \\
\text { groups. } \\
\text { It is not a question of kinship or clan } \\
\text { membership but of how well herders } \\
\text { know each other. Instead, exchange is } \\
\text { more likely to be mediated by daily } \\
\text { practices of herding in response to social, } \\
\text { political and environmental conditions. }\end{array}$ \\
\hline
\end{tabular}




\begin{tabular}{|c|c|c|c|c|c|c|c|c|c|}
\hline $\begin{array}{l}\text { Conley and } \\
\text { Udry } 2001\end{array}$ & $\begin{array}{l}\text { Explore agricultural } \\
\text { technology adoption } \\
\text { in Ghana with a focus } \\
\text { on communication } \\
\text { networks. }\end{array}$ & $\begin{array}{l}\text { Implicit reference to } \\
\text { resilience: } \\
\text { Learning about } \\
\text { technologies in social } \\
\text { networks as a central } \\
\text { feature of the trans- } \\
\text { formation of farming } \\
\text { systems in the context } \\
\text { of economic devel- } \\
\text { opment. }\end{array}$ & $\begin{array}{l}\text { Independent: } \\
\text { Impact of social } \\
\text { networks on the } \\
\text { adoption of agricultur- } \\
\text { al practices. }\end{array}$ & $\begin{array}{l}\text { Pipe: } \\
\text { Social networks as } \\
\text { conduit for the ex- } \\
\text { change of information } \\
\text { on agricultural tech- } \\
\text { niques. }\end{array}$ & $\begin{array}{l}\text { Descriptive: } \\
\text { Household survey in } \\
\text { four clusters of } \\
\text { villages. } \\
\text { Econometric } \\
\text { modeling. }\end{array}$ & 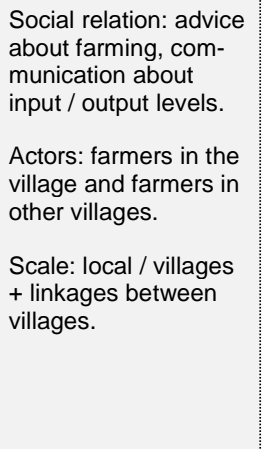 & Individual: farmers. & $\begin{array}{l}\text { Actor: plot level data } \\
\text { on input and output, } \\
\text { knowledge on input / } \\
\text { output level of other } \\
\text { farms. } \\
\text { Structure: density. }\end{array}$ & $\begin{array}{l}\text { Information is not freely available to all } \\
\text { farmers but channeled through sparse } \\
\text { networks and is often imperfect. } \\
\text { Farmers orient their behavior to the } \\
\text { behavior of other farmers they communi- } \\
\text { cate with. } \\
\text { Communication links are not based } \\
\text { solely on geographic proximity but } \\
\text { expand beyond the village level. } \\
\text { Farmers do not engage in optimal learn- } \\
\text { ing behavior. Instead, they use simple } \\
\text { rules of thumb to guide their behavior } \\
\text { when innovating. }\end{array}$ \\
\hline $\begin{array}{l}\text { Hoang et } \\
\text { al. } 2006\end{array}$ & \begin{tabular}{|l} 
Explore how social \\
networks function as \\
assets for individuals \\
and households and \\
how they influence \\
access to information \\
and benefits from \\
research and devel- \\
opment in rural areas \\
of North Vietnam.
\end{tabular} & $\begin{array}{l}\text { Implicit reference to } \\
\text { resilience: } \\
\text { Village communities } \\
\text { as heterogeneous } \\
\text { entities constituted by } \\
\text { complex networks of } \\
\text { social relationships. } \\
\text { Social networks as a } \\
\text { means of accessing } \\
\text { information from } \\
\text { research and devel- } \\
\text { opment. }\end{array}$ & $\begin{array}{l}\text { Independent: } \\
\text { Influence of social } \\
\text { networks information } \\
\text { access. }\end{array}$ & $\begin{array}{l}\text { Social capital: } \\
\text { Social networks as } \\
\text { important intangible } \\
\text { component of individ- } \\
\text { uals' or households' } \\
\text { asset-portfolios. }\end{array}$ & $\begin{array}{l}\text { Descriptive: } \\
\text { Semi-structured } \\
\text { interviews with } \\
\text { household represent- } \\
\text { atives in one rural } \\
\text { village. } \\
\text { SNA: total network } \\
\text { (but no explicit analy- } \\
\text { sis of network struc- } \\
\text { ture). }\end{array}$ & $\begin{array}{l}\text { Social relation: dis- } \\
\text { cussing, advice } \\
\text { seeking regarding } \\
\text { agricultural issues } \\
\text { and practices. } \\
\text { Actors: households in } \\
\text { the community, } \\
\text { external actors (other } \\
\text { households, exten- } \\
\text { sion, research). } \\
\text { Scale: local / village + } \\
\text { linkages to external } \\
\text { actors. }\end{array}$ & $\begin{array}{l}\text { Network: discussion / } \\
\text { advice network, } \\
\text { kinship network. }\end{array}$ & $\begin{array}{l}\text { Actor: relational } \\
\text { category, gender, } \\
\text { socio-economic } \\
\text { status. } \\
\text { Tie: kinship, neigh- } \\
\text { borhood / friendship } \\
\text { ties. } \\
\text { Context: political } \\
\text { influence. }\end{array}$ & $\begin{array}{l}\text { Differences in socio-economic status and } \\
\text { social connections through kinship, } \\
\text { friendship, and neighborhood networks } \\
\text { act as significant determinants of access } \\
\text { to information. } \\
\text { Close relatives are most trusted and } \\
\text { hence followed. Most discussion regard- } \\
\text { ing agricultural matters takes place at } \\
\text { home / at the village level. } \\
\text { Network analysis can avoid reinforcing } \\
\text { existing unequal power relations and can } \\
\text { enable research and development } \\
\text { interventions to reach the individuals and } \\
\text { households in greatest need. }\end{array}$ \\
\hline $\begin{array}{l}\text { Isaac et al. } \\
2007\end{array}$ & $\begin{array}{l}\text { Investigate the struc- } \\
\text { tural arrangements of } \\
\text { informal communica- } \\
\text { tion networks by } \\
\text { examining advice } \\
\text { seeking in the cocoa } \\
\text { agroforestry of Gha- } \\
\text { na. }\end{array}$ & $\begin{array}{l}\text { Implicit reference to } \\
\text { resilience: } \\
\text { Access to knowledge } \\
\text { is essential for com- } \\
\text { munity based adap- } \\
\text { tive management. } \\
\text { Farmers who lack the } \\
\text { means to acquire } \\
\text { farming knowledge } \\
\text { from formal sources } \\
\text { rely on information } \\
\text { within their informal } \\
\text { social networks. }\end{array}$ & $\begin{array}{l}\text { Independent: } \\
\text { Influence of social } \\
\text { structure on the } \\
\text { adoption of agrofor- } \\
\text { estry management } \\
\text { practices. }\end{array}$ & $\begin{array}{l}\text { Pipe: } \\
\text { Social networks as } \\
\text { informal conduits for } \\
\text { the transfer of } \\
\text { knowledge on agricul- } \\
\text { tural practices. }\end{array}$ & $\begin{array}{l}\text { Structurally explicit: } \\
\text { Household interviews } \\
\text { in four communities in } \\
\text { Ghana. } \\
\text { SNA: total network. }\end{array}$ & $\begin{array}{l}\text { Social relation: infor- } \\
\text { mal advice on farming } \\
\text { practices. } \\
\text { Actors: famers in four } \\
\text { communities, external } \\
\text { actors (farmers, } \\
\text { extension, and institu- } \\
\text { tions). } \\
\text { Scale: local } \\
\text { /community + linkages } \\
\text { to external actors. }\end{array}$ & $\begin{array}{l}\text { Network: community } \\
\text { advice network. } \\
\text { Individual: central / } \\
\text { bridging farmers. }\end{array}$ & $\begin{array}{l}\text { Actor: socio- } \\
\text { demographic data, } \\
\text { origin (in / outside the } \\
\text { community), level of } \\
\text { involvement, and level } \\
\text { of imitation. } \\
\text { Structure: density, } \\
\text { centrality }\end{array}$ & $\begin{array}{l}\text { Social proximity does not control the } \\
\text { formation of informal advice structures. } \\
\text { Advice networks are sparse networks } \\
\text { with a core-periphery structure. Few } \\
\text { central actors acting as bridging between } \\
\text { formal and informal networks. } \\
\\
\text { Central farmers are active in community } \\
\text { activities. Hence promotion of community } \\
\text { involvement may strengthen informal } \\
\text { networks. }\end{array}$ \\
\hline Isaac 2012 & \begin{tabular}{|l|} 
Investigate infor- \\
mation network \\
structures within the \\
agrarian environment \\
in order to understand \\
the barriers to, and \\
development of
\end{tabular} & $\begin{array}{l}\text { Implicit reference to } \\
\text { resilience: } \\
\text { The structure of social } \\
\text { networks connecting } \\
\text { a variety of agrarian } \\
\text { actors is fundamental }\end{array}$ & $\begin{array}{l}\text { Independent: } \\
\text { Impact of social } \\
\text { structure on effective- } \\
\text { ness of farm man- } \\
\text { agement. }\end{array}$ & $\begin{array}{l}\text { Pipe: } \\
\text { Social networks as } \\
\text { conduit for the ex- } \\
\text { change of agrarian } \\
\text { knowledge and }\end{array}$ & $\begin{array}{l}\text { Structurally explicit: } \\
\text { Semi-structured } \\
\text { interviews with farm- } \\
\text { ers and members of } \\
\text { organizations in two } \\
\text { geographically sepa- }\end{array}$ & $\begin{array}{l}\text { Social relation: advice } \\
\text { on the management } \\
\text { of agrodiversity on } \\
\text { cocoa farms. } \\
\text { Actors: famers, } \\
\text { external actors (ex- }\end{array}$ & $\begin{array}{l}\text { Network: farmers' } \\
\text { personal innovation } \\
\text { networks. } \\
\text { Individual: farmers. }\end{array}$ & $\begin{array}{l}\text { Actor: adoption rate of } \\
\text { agroforestry practices. } \\
\text { Tie: number of ties, } \\
\text { farmer-to-farmer ties, } \\
\text { organizational ties. }\end{array}$ & $\begin{array}{l}\text { The increase of organizational ties is } \\
\text { related to a decrease of network density } \\
\text { in personal producer networks as they } \\
\text { replace producer-to-producer ties. } \\
\text { Producers with ties to organizations are } \\
\text { likely to be positioned in more sparse and }\end{array}$ \\
\hline
\end{tabular}




\begin{tabular}{|c|c|c|c|c|c|c|c|c|c|}
\hline & $\begin{array}{l}\text { effective farm man- } \\
\text { agement, specifically } \\
\text { the management of } \\
\text { agrodiversity in } \\
\text { Ghana. }\end{array}$ & $\begin{array}{l}\text { to the adoption of } \\
\text { innovations and } \\
\text { influences the ad- } \\
\text { vancement or weak- } \\
\text { ening of sustainable } \\
\text { farm management. }\end{array}$ & & information & $\begin{array}{l}\text { rate rural areas. } \\
\text { SNA: ego-networks. }\end{array}$ & $\begin{array}{l}\text { tension, NGOs). } \\
\text { Scale: local / commu- } \\
\text { nity + linkages to } \\
\text { external actors. }\end{array}$ & & $\begin{array}{l}\text { Structure: size, } \\
\text { density, triad analysis. }\end{array}$ & $\begin{array}{l}\text { efficient information networks as identi- } \\
\text { fied by a low level of redundant ties } \\
\text { correlated to higher reported on-farm } \\
\text { agrodiversity. } \\
\text { Unlike common-pool resource manage- } \\
\text { ment which requires dense networks, } \\
\text { exchange of complex information re- } \\
\text { quires diffuse but efficient social net- } \\
\text { works. }\end{array}$ \\
\hline $\begin{array}{l}\text { Isaac et al. } \\
2014\end{array}$ & $\begin{array}{l}\text { Investigate the role of } \\
\text { migrant farmers in } \\
\text { agricultural infor- } \\
\text { mation networks and } \\
\text { explore implications } \\
\text { on the adoption of } \\
\text { pro-environmental } \\
\text { management practic- } \\
\text { es in Ghana. }\end{array}$ & $\begin{array}{l}\text { Explicit reference to } \\
\text { resilience: } \\
\text { Environmentally } \\
\text { induced migration as } \\
\text { a livelihood strategy } \\
\text { shaping agricultural } \\
\text { information networks } \\
\text { and therefore the } \\
\text { sustainable manage- } \\
\text { ment of agroecosys- } \\
\text { tems and the resili- } \\
\text { ence of the region of } \\
\text { destination. }\end{array}$ & $\begin{array}{l}\text { Dependent: } \\
\text { Influence of migration } \\
\text { on social networks } \\
\text { and their ability to } \\
\text { promote the adoption } \\
\text { of environmental } \\
\text { management } \\
\text { practices. }\end{array}$ & $\begin{array}{l}\text { Pipe: } \\
\text { Networks as conduit } \\
\text { for the exchange of } \\
\text { knowledge on agricul- } \\
\text { tural practices. }\end{array}$ & $\begin{array}{l}\text { Structurally explicit: } \\
\text { Famer interviews in } \\
\text { three rural communi- } \\
\text { ties. } \\
\text { SNA: total network } \\
\text { (constructed from } \\
\text { ego-networks). }\end{array}$ & $\begin{array}{l}\text { Social relation: } \\
\text { exchanging and } \\
\text { seeking information } \\
\text { on agricultural prac- } \\
\text { tices. } \\
\text { Actors: farmers in the } \\
\text { community and } \\
\text { farmers in other } \\
\text { communities. } \\
\text { Scale: local / commu- } \\
\text { nity + linkages be- } \\
\text { tween communities. }\end{array}$ & $\begin{array}{l}\text { Network: agricultural } \\
\text { communication } \\
\text { network. } \\
\text { Individual: farmers } \\
\text { (brokers). }\end{array}$ & $\begin{array}{l}\text { Actor: settlement } \\
\text { categories, origin and } \\
\text { location, demographic } \\
\text { data, land tenure, } \\
\text { adaptive practice, } \\
\text { brokerage roles. } \\
\text { Tie; tie-frequency } \\
\text { between communities. } \\
\text { Structure: size, } \\
\text { centrality, cohesion. } \\
\text { Context: migration. }\end{array}$ & $\begin{array}{l}\text { Cohesion of the communication network } \\
\text { is dependent on a few strategic bridging } \\
\text { ties initiated by migrant farmers. } \\
\text { Migrant farmers have larger networks, } \\
\text { act as brokers between socially and } \\
\text { spatial distant groups, and tend to apply } \\
\text { pro-environmental agricultural methods. } \\
\text { This can be conceptualized as social- } \\
\text { ecological memory. } \\
\text { Migrant farmers are potential agents of } \\
\text { innovation and adaptive management. }\end{array}$ \\
\hline $\begin{array}{l}\text { Matouš } \\
\text { et al. } 2013\end{array}$ & $\begin{array}{l}\text { Explore the roles of } \\
\text { social networks and } \\
\text { extension networks } \\
\text { for the adoption of } \\
\text { resource conserving } \\
\text { practices among } \\
\text { Ethiopian farmers. }\end{array}$ & $\begin{array}{l}\text { Implicit reference to } \\
\text { resilience: } \\
\text { Farmers' decisions } \\
\text { are influenced by } \\
\text { other farmers and the } \\
\text { nature of social } \\
\text { relationships. Informal } \\
\text { networks can play a } \\
\text { larger role in the } \\
\text { protection of natural } \\
\text { resources than formal } \\
\text { institutions. }\end{array}$ & $\begin{array}{l}\text { Independent: } \\
\text { Influence of social } \\
\text { networks on the } \\
\text { adoption of agricultur- } \\
\text { al techniques. }\end{array}$ & $\begin{array}{l}\text { Pipe: } \\
\text { Networks as conduit } \\
\text { for the exchange of } \\
\text { information. }\end{array}$ & $\begin{array}{l}\text { Descriptive: } \\
\text { Household survey } \\
\text { and semi-structured } \\
\text { interviews with local } \\
\text { extension staff in } \\
\text { three villages in three } \\
\text { agro-ecological } \\
\text { zones. } \\
\text { Econometric } \\
\text { analysis. }\end{array}$ & $\begin{array}{l}\text { Social relation: } \\
\text { information exchange } \\
\text { on resource conserv- } \\
\text { ing agricultural tech- } \\
\text { niques. } \\
\text { Actors: households in } \\
\text { the village and exter- } \\
\text { nal actors (extension } \\
\text { staff). } \\
\text { Scale: local / village + } \\
\text { linkages to external } \\
\text { actors. }\end{array}$ & $\begin{array}{l}\text { Individual: farmers. } \\
\text { Network: community } \\
\text { information network. }\end{array}$ & $\begin{array}{l}\text { Actor: wealth, ethno- } \\
\text { religious group, } \\
\text { knowledge about } \\
\text { resource conserving } \\
\text { practices, geographic } \\
\text { location. } \\
\text { Tie: internal / external } \\
\text { ties. } \\
\text { Structure: size, } \\
\text { density. }\end{array}$ & $\begin{array}{l}\text { Farmers living close to the village center, } \\
\text { with big land, bigger overall networks, } \\
\text { and same ethnicity are more likely to be } \\
\text { included in the extension system. } \\
\text { Same religion and ethnicity between } \\
\text { farmers and extension staff increases } \\
\text { likelihood of learning from extension. } \\
\text { Farmers with larger networks are more } \\
\text { likely to know an extension agent but } \\
\text { those are receptive to extension are } \\
\text { those who are less socially connected. }\end{array}$ \\
\hline $\begin{array}{l}\text { Matuschke } \\
\text { and Qaim } \\
2009\end{array}$ & $\begin{array}{l}\text { Examine the impact of } \\
\text { social networks on the } \\
\text { adoption of modern } \\
\text { seed technologies } \\
\text { among smallholder } \\
\text { farmers in rural India. }\end{array}$ & $\begin{array}{l}\text { Implicit reference to } \\
\text { resilience: } \\
\text { Social networks } \\
\text { impact the adoption of } \\
\text { agricultural innova- } \\
\text { tions and contribute to } \\
\text { increased agricultural } \\
\text { productivity and } \\
\text { reduced poverty. }\end{array}$ & $\begin{array}{l}\text { Independent: } \\
\text { Influence of social } \\
\text { networks on social } \\
\text { learning and technol- } \\
\text { ogy adoption. }\end{array}$ & $\begin{array}{l}\text { Pipe: } \\
\text { Networks as a conduit } \\
\text { enabling interaction } \\
\text { and knowledge } \\
\text { exchange between } \\
\text { farmers. }\end{array}$ & \begin{tabular}{|l|} 
Descriptive: \\
Household interviews \\
in seven villages in \\
four rural districts. \\
Econometric modeling \\
/ analysis.
\end{tabular} & $\begin{array}{l}\text { Social relation: regu- } \\
\text { larly talking about } \\
\text { agricultural decisions. } \\
\text { Actors: farmers in the } \\
\text { village and external } \\
\text { actors (farmers, } \\
\text { extension staff). } \\
\text { Scale: local / village, } \\
\text { linkages between } \\
\text { villages + linkages to } \\
\text { external actors. }\end{array}$ & Individual: farmers. & $\begin{array}{l}\text { Actor: education, } \\
\text { experience, farm size, } \\
\text { caste, adoption } \\
\text { behavior. } \\
\text { Tie: ties of kinship and } \\
\text { friendship. } \\
\text { Context: village } \\
\text { adoption rate, dis- } \\
\text { tance to input dealer / } \\
\text { market. }\end{array}$ & $\begin{array}{l}\text { Social networks do not necessarily } \\
\text { incidence with village boundaries. Hence, } \\
\text { relying on village level adoption rates } \\
\text { underestimates social network effects. } \\
\text { Communication takes place along homo- } \\
\text { philious rather than along heterogeneous } \\
\text { lines. } \\
\text { The behavior of members in the individu- } \\
\text { al network has bigger impact as their } \\
\text { characteristics. }\end{array}$ \\
\hline
\end{tabular}




\begin{tabular}{|c|c|c|c|c|c|c|c|c|c|}
\hline $\begin{array}{l}\text { Mazzucato } \\
\text { and } \\
\text { Niemeijer } \\
2000\end{array}$ & $\begin{array}{l}\text { Explore the role of } \\
\text { social institutions in } \\
\text { guiding decisions } \\
\text { regarding the use of } \\
\text { technologies drawing } \\
\text { on a case study from } \\
\text { Eastern Burkina Faso. }\end{array}$ & $\begin{array}{l}\text { Implicit reference to } \\
\text { resilience: } \\
\text { In order to understand } \\
\text { farmers' decision } \\
\text { making regarding soil } \\
\text { and water conserva- } \\
\text { tion technologies, it is } \\
\text { fundamental to un- } \\
\text { derstand local institu- } \\
\text { tions. These institu- } \\
\text { tions require invest- } \\
\text { ments in form of gift- } \\
\text { giving and exchanges } \\
\text { to build relationships. }\end{array}$ & $\begin{array}{l}\text { Independent / } \\
\text { Dependent: } \\
\text { Influence of social } \\
\text { networks on soil and } \\
\text { water conservation. } \\
\text { Influence of socio- } \\
\text { economic changes on } \\
\text { traditional social } \\
\text { networks. }\end{array}$ & $\begin{array}{l}\text { Pipe: } \\
\text { Social networks as } \\
\text { conduit for the ex- } \\
\text { change of technolo- } \\
\text { gies, information, } \\
\text { resources, and gifts. }\end{array}$ & $\begin{array}{l}\text { Metaphorical: } \\
\text { Interviews and obser- } \\
\text { vations in two villages } \\
\text { over a three-year } \\
\text { period. }\end{array}$ & $\begin{array}{l}\text { Social relation: recip- } \\
\text { rocal exchange of } \\
\text { labor, varieties, } \\
\text { technology, and land. } \\
\text { Actors: farmers in the } \\
\text { village, farmers in } \\
\text { other villages. } \\
\text { Scale: local / village + } \\
\text { linkages between } \\
\text { villages. }\end{array}$ & (not specified) & $\begin{array}{l}\text { Context: socio- } \\
\text { economic changes } \\
\text { (increasing market } \\
\text { integration). }\end{array}$ & $\begin{array}{l}\text { Mixing of market and social aspects has } \\
\text { led to changing use and composition of } \\
\text { networks. } \\
\text { Networks extending beyond the village } \\
\text { level are used to access a repertoire of } \\
\text { resources and technologies. This has } \\
\text { increased the ability to adapt to changes. } \\
\text { Technologies are more attractive if they } \\
\text { help maintain existing networks (lending } \\
\text { qualities of a technology). Intervention } \\
\text { should not only focus on technologies but } \\
\text { on how farmers' abilities to network can } \\
\text { be increased. }\end{array}$ \\
\hline $\begin{array}{l}\text { Spielman } \\
\text { et al. } 2010\end{array}$ & $\begin{array}{l}\text { Examine how Ethiopi- } \\
\text { an smallholders } \\
\text { innovate, how their } \\
\text { social networks } \\
\text { contribute to innova- } \\
\text { tion processes, and } \\
\text { how they are influ- } \\
\text { enced by policies and } \\
\text { market factors. }\end{array}$ & $\begin{array}{l}\text { Implicit reference to } \\
\text { resilience: } \\
\text { The way how small- } \\
\text { holders innovate and } \\
\text { improve their liveli- } \\
\text { hoods is under con- } \\
\text { stant change. Innova- } \\
\text { tion systems comprise } \\
\text { actors linked by } \\
\text { networks of } \\
\text { knowledge and others } \\
\text { exchanges. }\end{array}$ & $\begin{array}{l}\text { Independent: } \\
\text { Influence of social } \\
\text { networks on innova- } \\
\text { tion adoption. }\end{array}$ & $\begin{array}{l}\text { Pipe: } \\
\text { Networks as a conduit } \\
\text { for the exchange of } \\
\text { information, inputs, } \\
\text { and credit within the } \\
\text { innovation system. }\end{array}$ & $\begin{array}{l}\text { Structurally explicit: } \\
\text { Household interviews, } \\
\text { focus group discus- } \\
\text { sions, and semi- } \\
\text { structured interviews } \\
\text { with key actors in } 10 \\
\text { case study locations. } \\
\text { SNA: total network. }\end{array}$ & $\begin{array}{l}\text { Social relation: ex- } \\
\text { change of knowledge, } \\
\text { inputs, credit, finance, } \\
\text { price and market } \\
\text { information. } \\
\text { Actors: actors of the } \\
\text { innovation system: } \\
\text { farmers, extension } \\
\text { staff, private and } \\
\text { public sector repre- } \\
\text { sentatives. } \\
\text { Scale: local - national } \\
\text { innovation system. }\end{array}$ & $\begin{array}{l}\text { Network: national } \\
\text { innovation system. } \\
\text { Individual: brokering } \\
\text { organizations. }\end{array}$ & $\begin{array}{l}\text { Actor: socio-economic } \\
\text { / demographic data, } \\
\text { adoption behavior, } \\
\text { group affiliation } \\
\text { (private sector, NGO, } \\
\text { extension, etc.). } \\
\text { Tie: bridging links. } \\
\text { Structure: centrality, } \\
\text { coreness, cliques, } \\
\text { and structural holes. } \\
\text { Context: political } \\
\text { influence. }\end{array}$ & $\begin{array}{l}\text { Heterogeneous and integrated networks } \\
\text { provide farmers with greater livelihood } \\
\text { options. } \\
\text { Interconnected public organizations play } \\
\text { a central role, while market and civil } \\
\text { society actors play only a peripheral role. } \\
\text { Public extension and administration exert } \\
\text { a strong influence over smallholder } \\
\text { networks. By crowding out market-based } \\
\text { and civil society actors the public sectors } \\
\text { potentially limits beneficial innovation } \\
\text { processes. }\end{array}$ \\
\hline $\begin{array}{l}\text { Tatlonghari } \\
\text { et al. } 2012\end{array}$ & $\begin{array}{l}\text { Investigate the struc- } \\
\text { ture of information } \\
\text { exchange among } \\
\text { male and female } \\
\text { farmers involved in a } \\
\text { project on participa- } \\
\text { tory variety selection } \\
\text { in Laos and Indone- } \\
\text { sia. }\end{array}$ & $\begin{array}{l}\text { Implicit reference to } \\
\text { resilience: } \\
\text { Social capital in form } \\
\text { of social networks } \\
\text { among farmers can } \\
\text { enhance the adoption } \\
\text { of sustainable re- } \\
\text { source practices and } \\
\text { can promote food } \\
\text { security and income } \\
\text { generation. }\end{array}$ & $\begin{array}{l}\text { Independent: } \\
\text { Impact of social } \\
\text { networks on the } \\
\text { adoption of new } \\
\text { seeds. }\end{array}$ & $\begin{array}{l}\text { Social capital: } \\
\text { Social networks can } \\
\text { serve as a form of } \\
\text { social capital, and } \\
\text { hence are an im- } \\
\text { portant intangible } \\
\text { component of individ- } \\
\text { uals' and households' } \\
\text { asset portfolios. }\end{array}$ & $\begin{array}{l}\text { Descriptive: } \\
\text { Household surveys in } \\
\text { two study villages in } \\
\text { Laos and Indonesia. } \\
\text { Econometric modeling } \\
\text { / analysis. }\end{array}$ & $\begin{array}{l}\text { Social relation: ex- } \\
\text { change of information } \\
\text { on seeds. } \\
\text { Actors: friends, family } \\
\text { members, external } \\
\text { actors (formal institu- } \\
\text { tions). } \\
\text { Scale: local / village + } \\
\text { linkages between } \\
\text { communities + linkag- } \\
\text { es to external actors. }\end{array}$ & $\begin{array}{l}\text { Subgroup: groups of } \\
\text { kinship / friendship. }\end{array}$ & $\begin{array}{l}\text { Actor: gender of the } \\
\text { respondent, age, } \\
\text { years in school, } \\
\text { household size, area } \\
\text { cultivated, number of } \\
\text { relatives, membership } \\
\text { in organizations, and } \\
\text { access to extension } \\
\text { services and social } \\
\text { institutions. } \\
\text { Structure: size of } \\
\text { subgroups. }\end{array}$ & $\begin{array}{l}\text { Farmers are strongly influenced by their } \\
\text { kin and friends. Having more relatives } \\
\text { increases the likelihood of having a big } \\
\text { network. } \\
\text { Information opportunities of men and } \\
\text { women vary in terms of exposure to and } \\
\text { control of information. Men tend to have } \\
\text { larger networks than women. } \\
\text { Gender should be accounted for when } \\
\text { investigating the determinants of social } \\
\text { networks. }\end{array}$ \\
\hline $\begin{array}{l}\text { Thuo et al. } \\
2014\end{array}$ & $\begin{array}{l}\text { Examine the effects of } \\
\text { social network factors } \\
\text { on information acqui- } \\
\text { sition and adoption of } \\
\text { new seed varieties } \\
\text { among groundnut } \\
\text { farmers in Uganda } \\
\text { and Kenya. }\end{array}$ & $\begin{array}{l}\text { Implicit reference to } \\
\text { resilience: } \\
\text { Social networks play } \\
\text { a key role for social } \\
\text { learning, and hence } \\
\text { the adoption of new } \\
\text { agricultural practices. }\end{array}$ & $\begin{array}{l}\text { Independent: } \\
\text { Influence of social } \\
\text { networks on infor- } \\
\text { mation acquisition } \\
\text { and the adoption of } \\
\text { new seeds. }\end{array}$ & $\begin{array}{l}\text { Pipe } \\
\text { Networks as a conduit } \\
\text { for the exchange of } \\
\text { information. }\end{array}$ & $\begin{array}{l}\text { Descriptive: } \\
\text { Household interviews } \\
\text { in two study sites. } \\
\text { Econometric modeling } \\
\text { / analysis. }\end{array}$ & $\begin{array}{l}\text { Social relation: } \\
\text { discussing groundnut } \\
\text { matters, support } \\
\text { towards better } \\
\text { productivity. } \\
\text { Actors: farmers and } \\
\text { external actors (ex- } \\
\text { tension staff, input }\end{array}$ & Individual: farmers. & $\begin{array}{l}\text { Actor: socioeconomic } \\
\text { / demographic data, } \\
\text { location, gender. } \\
\text { Tie: tie strength, } \\
\text { bonding / bridging ties } \\
\text { (internal or external } \\
\text { sources of infor- }\end{array}$ & $\begin{array}{l}\text { Information flows in social networks are } \\
\text { strong among farmers with similar char- } \\
\text { acteristics. } \\
\text { Particular weak ties to external support } \\
\text { (research, extension etc.) influence } \\
\text { information acquisition but not necessari- } \\
\text { ly adoption. As well, gender and geo- } \\
\text { graphic location determine information }\end{array}$ \\
\hline
\end{tabular}




\begin{tabular}{|c|c|c|c|c|c|c|c|c|c|}
\hline & & & & & & $\begin{array}{l}\text { supplier, and re- } \\
\text { searchers) } \\
\\
\text { Scale: local / village + } \\
\text { linkages to external } \\
\text { actors. }\end{array}$ & & mation). & acquisition. \\
\hline $\begin{array}{l}\text { Van den } \\
\text { Broeck and } \\
\text { Dercon } \\
2011\end{array}$ & $\begin{array}{l}\text { Explore the role of } \\
\text { social networks as } \\
\text { facilitators of infor- } \\
\text { mation flows and } \\
\text { social externalities of } \\
\text { banana production in } \\
\text { a Tanzanian village. }\end{array}$ & $\begin{array}{l}\text { Implicit reference to } \\
\text { resilience: } \\
\text { Social networks } \\
\text { facilitating information } \\
\text { flows and "learning } \\
\text { from others" between } \\
\text { farmers. }\end{array}$ & $\begin{array}{l}\text { Independent: } \\
\text { Influence of social } \\
\text { networks on infor- } \\
\text { mation flows and } \\
\text { social externalities of } \\
\text { banana production. }\end{array}$ & $\begin{array}{l}\text { Pipe: } \\
\text { Networks as a conduit } \\
\text { for the exchange of } \\
\text { information flows. }\end{array}$ & $\begin{array}{l}\text { Descriptive: } \\
\text { Full village / house- } \\
\text { hold census in one } \\
\text { village. } \\
\text { Econometric analysis. }\end{array}$ & $\begin{array}{l}\text { Social relation: advice } \\
\text { seeking and infor- } \\
\text { mation exchange } \\
\text { related to banana } \\
\text { production. } \\
\text { Actors: farmers in the } \\
\text { village. } \\
\text { Scale: local / village. }\end{array}$ & Individual: farmers. & $\begin{array}{l}\text { Actor: social roles } \\
\text { (kinship, neighbor- } \\
\text { hood and member- } \\
\text { ship in self-reported } \\
\text { insurance groups). } \\
\text { Tie: tie strength } \\
\text { (internal / external } \\
\text { ties). }\end{array}$ & $\begin{array}{l}\text { Social learning is imperfect and requires } \\
\text { strong networks such as kinship net- } \\
\text { works. } \\
\text { Being part of a larger kinship network or } \\
\text { living closer to other famers suppresses } \\
\text { the likelihood of having outside infor- } \\
\text { mation sources. } \\
\text { In order to obtain biggest social externali- } \\
\text { ties those farmers should be addressed } \\
\text { belonging to different kinship groups. }\end{array}$ \\
\hline $\begin{array}{l}\text { van Rijn } \\
\text { et al. } 2012\end{array}$ & $\begin{array}{l}\text { Explore the relation } \\
\text { between different } \\
\text { forms of social capital } \\
\text { and agricultural } \\
\text { innovations for a } \\
\text { sample of African } \\
\text { countries. }\end{array}$ & $\begin{array}{l}\text { Implicit reference to } \\
\text { resilience: } \\
\text { Agricultural innovation } \\
\text { is an important factor } \\
\text { for economic growth } \\
\text { and development. } \\
\text { Structural social } \\
\text { capital of the poor can } \\
\text { fosters the adoption of } \\
\text { new agricultural } \\
\text { technologies. }\end{array}$ & $\begin{array}{l}\text { Independent: } \\
\text { Influence of social } \\
\text { networks on agricul- } \\
\text { tural innovation. }\end{array}$ & $\begin{array}{l}\text { Social capital: } \\
\text { Social networks as } \\
\text { structural capital } \\
\text { (bonding-, and bridg- } \\
\text { ing social capital). }\end{array}$ & \begin{tabular}{|l|} 
Descriptive: \\
Household survey \\
and village survey in \\
seven African coun- \\
tries. \\
Assessment of an \\
adaptation index and \\
social capital indica- \\
tors. \\
Econometric modeling \\
/ analysis.
\end{tabular} & $\begin{array}{l}\text { Social relation: con- } \\
\text { nections between } \\
\text { households at village } \\
\text { national level (not } \\
\text { specified). } \\
\text { Actors: households in } \\
\text { the village and exter- } \\
\text { nal actors (not speci- } \\
\text { fied). } \\
\text { Scale: local / village + } \\
\text { linkages to external } \\
\text { actors. }\end{array}$ & $\begin{array}{l}\text { Subgroups: social } \\
\text { capital groups. }\end{array}$ & $\begin{array}{l}\text { Actors: level of educa- } \\
\text { tion, experience of the } \\
\text { household in farming, } \\
\text { household wealth. } \\
\text { Tie: bonding ties } \\
\text { (between kin), bridg- } \\
\text { ing ties (linkages } \\
\text { across groups). } \\
\text { Context: presence of } \\
\text { mobile phone net- } \\
\text { works, schooling } \\
\text { facilities and water } \\
\text { resources. }\end{array}$ & $\begin{array}{l}\text { Participation in wider networks that } \\
\text { extend beyond the local village correlates } \\
\text { with more innovation. This could be due } \\
\text { to enhanced information or better access } \\
\text { to resources. } \\
\text { Participation in horizontal (intra- } \\
\text { community) networks does not appear to } \\
\text { be significantly correlated with innova- } \\
\text { tions. }\end{array}$ \\
\hline $\begin{array}{l}\text { Wossen } \\
\text { et al. } 2013\end{array}$ & $\begin{array}{l}\text { Examine how the } \\
\text { structure and size of } \\
\text { networks affect social } \\
\text { learning and farmers' } \\
\text { decision to adopt } \\
\text { sustainable resource } \\
\text { management practic- } \\
\text { es. }\end{array}$ & $\begin{array}{l}\text { Implicit reference to } \\
\text { resilience: } \\
\text { Social networks as a } \\
\text { central determinant of } \\
\text { the adoption of new } \\
\text { technologies. Net- } \\
\text { works reduce expo- } \\
\text { sure to risks and are } \\
\text { essential in enhancing } \\
\text { agricultural productivi- } \\
\text { ty and food security. }\end{array}$ & $\begin{array}{l}\text { Independent: } \\
\text { Impact of structure } \\
\text { and size of social } \\
\text { networks on adoption } \\
\text { decisions. }\end{array}$ & $\begin{array}{l}\text { Pipe: } \\
\text { Networks as a conduit } \\
\text { for the exchange of } \\
\text { information from } \\
\text { different sources. }\end{array}$ & 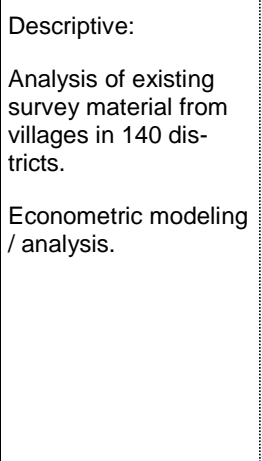 & $\begin{array}{l}\text { Social relation: ex- } \\
\text { change of information, } \\
\text { learning about new } \\
\text { technologies. } \\
\text { Actors: farmers, } \\
\text { external actors (ex- } \\
\text { tension, public / } \\
\text { private institutions). } \\
\text { Scale: local / village + } \\
\text { linkages to external } \\
\text { actors. }\end{array}$ & Individual: farmers. & $\begin{array}{l}\text { Actor: social roles } \\
\text { (kin, friends, neigh- } \\
\text { bors) educational } \\
\text { level, age, plot loca- } \\
\text { tion, distance from the } \\
\text { peer, distance of } \\
\text { network members } \\
\text { relative to each other. } \\
\text { Tie: kinship- / friend- } \\
\text { ship ties, neighbor- } \\
\text { hood ties. } \\
\text { Network: number of } \\
\text { ties (size). }\end{array}$ & $\begin{array}{l}\text { Social network size and type of ties (e.g. } \\
\text { kinship) play a significant role in enhanc- } \\
\text { ing the adoption of natural resource } \\
\text { management practices. } \\
\text { Adoption of new natural resource man- } \\
\text { agement practices is more frequent } \\
\text { among farmers whose plot is located } \\
\text { next to adopters ("learning by watching"). } \\
\text { Distance between network members has } \\
\text { a positive effect on the adoption of new } \\
\text { technologies. External sources of infor- } \\
\text { mation such as extension play a crucial } \\
\text { role in enhancing the adoption of re- } \\
\text { source management practices. }\end{array}$ \\
\hline
\end{tabular}


Table A1.3: Strand iii: Social support

\begin{tabular}{|c|c|c|c|c|c|c|c|c|c|}
\hline \multirow[t]{3}{*}{ Authors } & \multirow[t]{3}{*}{ Research interest } & \multicolumn{3}{|c|}{ Conceptualization } & \multicolumn{4}{|c|}{ Operationalization } & \multirow[t]{3}{*}{ Key findings } \\
\hline & & \multirow{2}{*}{$\begin{array}{c}\text { Conceptual } \\
\text { framing }\end{array}$} & \multirow{2}{*}{$\begin{array}{l}\text { Network } \\
\text { variable }\end{array}$} & \multirow{2}{*}{$\begin{array}{l}\text { Network } \\
\text { narrative }\end{array}$} & \multirow[t]{2}{*}{ Network approach } & \multirow{2}{*}{$\begin{array}{l}\text { Network } \\
\text { definition }\end{array}$} & \multicolumn{2}{|c|}{ Network analysis } & \\
\hline & & & & & & & Network level & Network characteristics & \\
\hline $\begin{array}{l}\text { Abizaid } \\
\text { et al. } 2015\end{array}$ & $\begin{array}{l}\text { Employ an analytic } \\
\text { approach for the } \\
\text { study of labor sharing } \\
\text { networks among } \\
\text { peasant households } \\
\text { in the Peruvian } \\
\text { Amazon. }\end{array}$ & $\begin{array}{l}\text { Implicit reference to } \\
\text { resilience: } \\
\text { Social relations shape } \\
\text { peasant resource use } \\
\text { and livelihood security } \\
\text { in rural areas. Labor } \\
\text { exchange as a strate- } \\
\text { gy to cope with } \\
\text { seasonal labor short- } \\
\text { age and cash limita- } \\
\text { tions. }\end{array}$ & $\begin{array}{l}\text { Independent: } \\
\text { Influence of kinship } \\
\text { networks and house- } \\
\text { hold structure on the } \\
\text { availability of labor } \\
\text { exchange. }\end{array}$ & $\begin{array}{l}\text { Pipe: } \\
\text { Social networks as } \\
\text { source of labor sup- } \\
\text { port in times of labor } \\
\text { shortage. }\end{array}$ & $\begin{array}{l}\text { Structurally explicit: } \\
\text { Observation, focus } \\
\text { groups discussions } \\
\text { with key informants, } \\
\text { and complete house- } \\
\text { hold / village census } \\
\text { in a mountain village. } \\
\text { SNA: total network. }\end{array}$ & $\begin{array}{l}\text { Social relation: } \\
\text { exchange of labor. } \\
\text { Actors: households in } \\
\text { the village. } \\
\text { Scale: local / village. }\end{array}$ & $\begin{array}{l}\text { Network: village labor } \\
\text { sharing network. } \\
\text { Subgroup: kinship / } \\
\text { gender groups. }\end{array}$ & $\begin{array}{l}\text { Actor: household } \\
\text { affiliation, gender, } \\
\text { income, assets, and } \\
\text { land use. } \\
\text { Tie: ties between } \\
\text { women / men, kinship } \\
\text { ties, tie intensity. }\end{array}$ & $\begin{array}{l}\text { Structure and flows of labor within the } \\
\text { network are shaped by how households } \\
\text { are connected through relational net- } \\
\text { works at personal and group level. } \\
\text { Participation in and access to coopera- } \\
\text { tive labor is markedly unequal. Women's } \\
\text { personal networks play an important role } \\
\text { in the mobilization of cooperative labor. } \\
\text { Cooperative labor is not always recipro- } \\
\text { cal in the short term. }\end{array}$ \\
\hline $\begin{array}{l}\text { Baird and } \\
\text { Gray } 2014\end{array}$ & $\begin{array}{l}\text { Investigate the influ- } \\
\text { ence of livelihood } \\
\text { diversification on } \\
\text { traditional support } \\
\text { networks in terms of } \\
\text { bonding and bridging } \\
\text { ties in Maasai com- } \\
\text { munities in northern } \\
\text { Tanzania. }\end{array}$ & $\begin{array}{l}\text { Explicit reference to } \\
\text { resilience: } \\
\text { Traditional social } \\
\text { networks of exchange } \\
\text { and reciprocity are } \\
\text { critical components of } \\
\text { household security, } \\
\text { disaster relief, and } \\
\text { household resilience } \\
\text { in rural areas. Social } \\
\text { networks are evolving } \\
\text { in response to house- } \\
\text { hold diversification. }\end{array}$ & $\begin{array}{l}\text { Dependent: } \\
\text { Influence of income } \\
\text { diversification on } \\
\text { networks of traditional } \\
\text { inter-household } \\
\text { exchanges. }\end{array}$ & $\begin{array}{l}\text { Social capital: } \\
\text { Social networks as } \\
\text { important component } \\
\text { of social capital. } \\
\text { Different networks } \\
\text { confer different types } \\
\text { of social capital on } \\
\text { their members. }\end{array}$ & $\begin{array}{l}\text { Descriptive: } \\
\text { Semi-structured group } \\
\text { interviews and } \\
\text { household survey in } \\
\text { six communities. } \\
\text { Livelihood diversifica- } \\
\text { tion index. } \\
\text { Regression analysis. }\end{array}$ & $\begin{array}{l}\text { Social relation: } \\
\text { exchanges of } \\
\text { resources between } \\
\text { households (loans, } \\
\text { restocking, and gifts). } \\
\text { Actors: households in } \\
\text { the community. } \\
\text { Scale: local / commu- } \\
\text { nity. }\end{array}$ & $\begin{array}{l}\text { Individual: house- } \\
\text { holds. }\end{array}$ & $\begin{array}{l}\text { Actors: socio- } \\
\text { economic / demo- } \\
\text { graphic data, church } \\
\text { participation, percep- } \\
\text { tion of household } \\
\text { exchanges. } \\
\text { Ties: number and } \\
\text { content of exchanges, } \\
\text { bonding and bridging } \\
\text { ties. }\end{array}$ & $\begin{array}{l}\text { The transition of risk management holds } \\
\text { several implications for the growth, } \\
\text { development, and resilience of house- } \\
\text { holds and communities. } \\
\text { Reducing household exchanges might } \\
\text { reduce the ability to act collectively. } \\
\text { Diversified households may be able to } \\
\text { better manage high incidence / low } \\
\text { severity shocks but may be less well } \\
\text { prepared to manage low incidence / high } \\
\text { severity shocks. } \\
\text { Declining inter-household exchanges } \\
\text { (bonding ties) releases resources that } \\
\text { could be invested in household diversifi- } \\
\text { cation (bridging ties). }\end{array}$ \\
\hline $\begin{array}{l}\text { Bosher } \\
\text { et al. } 2007\end{array}$ & $\begin{array}{l}\text { Explore key factors } \\
\text { determining who has } \\
\text { assets, who can } \\
\text { access public facili- } \\
\text { ties, who has political } \\
\text { connections, and who } \\
\text { has supportive social } \\
\text { networks for coping } \\
\text { with environmental } \\
\text { risk in coastal com- } \\
\text { munities in Andhra } \\
\text { Pradesh, India. }\end{array}$ & $\begin{array}{l}\text { Explicit reference to } \\
\text { resilience: } \\
\text { Social networks } \\
\text { provide social capital } \\
\text { that can bolster the } \\
\text { resilience of the poor } \\
\text { and vulnerable to } \\
\text { environmental risks. }\end{array}$ & $\begin{array}{l}\text { Independent / } \\
\text { Dependent: } \\
\text { Influence of social } \\
\text { networks on the } \\
\text { resilience of poor } \\
\text { households. } \\
\text { Caste influence on } \\
\text { access to social } \\
\text { networks. }\end{array}$ & $\begin{array}{l}\text { Social capital: } \\
\text { Social networks as } \\
\text { component of social } \\
\text { capital providing } \\
\text { access to resources } \\
\text { that can substitute } \\
\text { other capitals and } \\
\text { enhance resilience. }\end{array}$ & $\begin{array}{l}\text { Descriptive: } \\
\text { Key informant inter- } \\
\text { views, household } \\
\text { interviews, and } \\
\text { sociograms in eight } \\
\text { coastal villages. } \\
\text { Vulnerability index. } \\
\text { Descriptive statistics. }\end{array}$ & $\begin{array}{l}\text { Social relation: con- } \\
\text { nections to NGOs, } \\
\text { CBOs and family } \\
\text { members. } \\
\text { Actors: households, } \\
\text { CBOs, external actors } \\
\text { (NGOs, politicians). } \\
\text { Scale: local / village + } \\
\text { linkages to external } \\
\text { actors. }\end{array}$ & $\begin{array}{l}\text { Individual: house- } \\
\text { holds. }\end{array}$ & $\begin{array}{l}\text { Actor: caste, vulnera- } \\
\text { bility index. } \\
\text { Tie: tie type, tie } \\
\text { strength (internal / } \\
\text { external). }\end{array}$ & $\begin{array}{l}\text { Caste is a decisive factor determining the } \\
\text { access to particular supportive networks. } \\
\text { The poor and powerless castes (those } \\
\text { with poor access to political social net- } \\
\text { works) are dependent on their informal } \\
\text { social networks. These networks are } \\
\text { typically accessed via the involvement } \\
\text { with NGOs. }\end{array}$ \\
\hline
\end{tabular}




\begin{tabular}{|c|c|c|c|c|c|c|c|c|c|}
\hline $\begin{array}{l}\text { Cassidy } \\
\text { and Barnes } \\
2012\end{array}$ & $\begin{array}{l}\text { Explore the relation- } \\
\text { ship between house- } \\
\text { hold connectivity and } \\
\text { household resilience } \\
\text { to shocks such as } \\
\text { illness, crop damage, } \\
\text { and livestock diseas- } \\
\text { es in a rural communi- } \\
\text { ty in Botswana. }\end{array}$ & $\begin{array}{l}\text { Explicit reference to } \\
\text { resilience: } \\
\text { Social networks as a } \\
\text { strategy of vulnerable } \\
\text { rural households to } \\
\text { deal with external and } \\
\text { internal stresses and } \\
\text { shocks and to in- } \\
\text { crease their resili- } \\
\text { ence. }\end{array}$ & $\begin{array}{l}\text { Independent: } \\
\text { Influence of network } \\
\text { structure on house- } \\
\text { hold resilience to } \\
\text { environmental risks / } \\
\text { economic stress. }\end{array}$ & $\begin{array}{l}\text { Pipe / Social capital: } \\
\text { Social networks as a } \\
\text { conduit for the ex- } \\
\text { change of resources. } \\
\text { Social networks as } \\
\text { one aspect of social } \\
\text { capital. }\end{array}$ & $\begin{array}{l}\text { Structurally explicit: } \\
\text { Focus group and } \\
\text { complete household } \\
\text { survey in a rural } \\
\text { village. } \\
\text { Household resilience } \\
\text { index. } \\
\text { SNA: total network. }\end{array}$ & $\begin{array}{l}\text { Social relation: ex- } \\
\text { change of information, } \\
\text { labor, food, or money } \\
\text { in times of stress. } \\
\text { Actors: households in } \\
\text { the village. } \\
\text { Scale: local / village. }\end{array}$ & $\begin{array}{l}\text { Network: village } \\
\text { support network. } \\
\text { Individual: house- } \\
\text { holds. }\end{array}$ & $\begin{array}{l}\text { Actor: socio-economic } \\
\text { and demographic } \\
\text { data, resilience index } \\
\text { (including wealth, } \\
\text { livelihood diversity, } \\
\text { household capitals). } \\
\text { Structure: centrality. }\end{array}$ & $\begin{array}{l}\text { Households that are better connected } \\
\text { have higher resilience, because of higher } \\
\text { redundancy and reach of ties into differ- } \\
\text { ent subsets of the community. } \\
\text { Unequal distribution of capitals is corre- } \\
\text { lated with unequal distribution of connec- } \\
\text { tivity. } \\
\text { Already marginalized households are } \\
\text { less connected. }\end{array}$ \\
\hline $\begin{array}{l}\text { da Costa } \\
\text { et al. } 2012\end{array}$ & $\begin{array}{l}\text { Understanding } \\
\text { household food } \\
\text { security and, inter } \\
\text { alia, the role of food } \\
\text { exchange in Timor- } \\
\text { Leste. }\end{array}$ & $\begin{array}{l}\text { Explicit reference to } \\
\text { resilience: } \\
\text { Social networks as a } \\
\text { coping strategy for } \\
\text { rural households and } \\
\text { as a contribution to } \\
\text { resilience of agricul- } \\
\text { tural systems to } \\
\text { climatic risks. }\end{array}$ & $\begin{array}{l}\text { Independent: } \\
\text { Influence on social } \\
\text { networks on house- } \\
\text { hold food security. }\end{array}$ & $\begin{array}{l}\text { Pipe: } \\
\text { Social networks as } \\
\text { conduit for the recip- } \\
\text { rocal exchange of } \\
\text { food. }\end{array}$ & $\begin{array}{l}\text { Metaphorical: } \\
\text { Review based on } \\
\text { national household } \\
\text { survey / consumption } \\
\text { study. }\end{array}$ & $\begin{array}{l}\text { Social relation: recip- } \\
\text { rocal gifting of food. } \\
\text { Actors: households. } \\
\text { Scale: (not specified) }\end{array}$ & (not specified) & $\begin{array}{l}\text { Tie: reciprocity of food } \\
\text { exchanges. }\end{array}$ & $\begin{array}{l}\text { The gifting of food between neighbors } \\
\text { and members of extended families } \\
\text { functions as 'delayed reciprocity' where- } \\
\text { by the gift is returned at a later date when } \\
\text { the household that has received the gift } \\
\text { has a surplus or when other households } \\
\text { experience shortage. }\end{array}$ \\
\hline $\begin{array}{l}\text { Downey } \\
2010\end{array}$ & $\begin{array}{l}\text { Examine the influence } \\
\text { of labor exchange } \\
\text { networks on the } \\
\text { socio-ecological } \\
\text { resilience of rural } \\
\text { Mayan communities } \\
\text { in Belize and identify } \\
\text { relevant network } \\
\text { properties. }\end{array}$ & $\begin{array}{l}\text { Explicit reference to } \\
\text { resilience: } \\
\text { Labor exchange } \\
\text { networks contribute to } \\
\text { village cohesion and } \\
\text { adaptive manage- } \\
\text { ment, and therefore to } \\
\text { community resilience } \\
\text { in the context of } \\
\text { socio-economic and } \\
\text { environmental chang- } \\
\text { es. }\end{array}$ & $\begin{array}{l}\text { Independent: } \\
\text { Influence of social } \\
\text { networks on the } \\
\text { resilience of rural } \\
\text { communities / social- } \\
\text { ecological systems. }\end{array}$ & $\begin{array}{l}\text { Pipe / } \\
\text { Form of coordination: } \\
\text { Social networks as } \\
\text { conduit for the ex- } \\
\text { change of labor and } \\
\text { information. } \\
\text { Networks as a form of } \\
\text { managing resource } \\
\text { use. }\end{array}$ & $\begin{array}{l}\text { Structurally explicit: } \\
\text { Analysis of historical } \\
\text { land uses and com- } \\
\text { plete household } \\
\text { census in five study } \\
\text { villages. } \\
\text { SNA: total network. }\end{array}$ & $\begin{array}{l}\text { Social relation: ex- } \\
\text { change of labor for } \\
\text { clearing and planting } \\
\text { fields. } \\
\text { Actors: households in } \\
\text { the village. } \\
\text { Scale: local / village. }\end{array}$ & $\begin{array}{l}\text { Network: village labor } \\
\text { exchange network. }\end{array}$ & $\begin{array}{l}\text { Actor: field size, } \\
\text { crops planted, and } \\
\text { productivity. } \\
\text { Tie: ratio of recipro- } \\
\text { cated / unreciprocat- } \\
\text { ed ties. } \\
\text { Structure: group size, } \\
\text { herarchy. }\end{array}$ & $\begin{array}{l}\text { Labor networks not only increase a } \\
\text { farmer's ability to coordinate large labor } \\
\text { groups, they also enhance learning and } \\
\text { adaptation. } \\
\text { Increasing reciprocity rates can increase } \\
\text { production, whereas decreasing reciproc- } \\
\text { ity can help protecting shared resources } \\
\text { from overuse. } \\
\text { Resilience is not increased by developing } \\
\text { fragile institutional hierarchies to protect } \\
\text { common resources, but by the connec- } \\
\text { tive properties of networks. }\end{array}$ \\
\hline $\begin{array}{l}\text { Ekblom } \\
2012\end{array}$ & $\begin{array}{l}\text { Assess vulnerability } \\
\text { and resilience in rural } \\
\text { communities in South } \\
\text { Mozambique from a } \\
\text { historical perspective, } \\
\text { including the role of } \\
\text { social networks. }\end{array}$ & $\begin{array}{l}\text { Explicit reference to } \\
\text { resilience: } \\
\text { Resilience as the } \\
\text { capacity of a society } \\
\text { to respond to and } \\
\text { recover from adverse } \\
\text { conditions. Social } \\
\text { networks as a liveli- } \\
\text { hood strategy affect- } \\
\text { ing the capacity to } \\
\text { cope with vulnerabili- } \\
\text { ties. }\end{array}$ & $\begin{array}{l}\text { Independent: } \\
\text { Influence of social } \\
\text { networks on resilience } \\
\text { / vulnerability of rural } \\
\text { communities. }\end{array}$ & $\begin{array}{l}\text { Pipe: } \\
\text { Social networks as } \\
\text { conduit for the ex- } \\
\text { change of resources. }\end{array}$ & $\begin{array}{l}\text { Metaphorical: } \\
\text { Semi-structured } \\
\text { interviews with key } \\
\text { informants and } \\
\text { household interviews } \\
\text { in a rural commune. } \\
\text { Geological data and } \\
\text { pollen analysis. }\end{array}$ & $\begin{array}{l}\text { Social relation: kin- } \\
\text { ship ties, labor ex- } \\
\text { change, information } \\
\text { sharing, remittances. } \\
\text { Actors: households in } \\
\text { the commune, exter- } \\
\text { nal actors (not speci- } \\
\text { fied). } \\
\text { Scale: local / com- } \\
\text { mune + national / } \\
\text { international linkages. } \\
\text { Temporal scale: } \\
700 \text { AD until today. }\end{array}$ & $\begin{array}{l}\text { Individual: house- } \\
\text { holds. }\end{array}$ & $\begin{array}{l}\text { Ties: internal / exter- } \\
\text { nal linkages. } \\
\text { Context: commerciali- } \\
\text { zation of natural } \\
\text { resources use, trade, } \\
\text { and migration. }\end{array}$ & $\begin{array}{l}\text { Household exchange as an important } \\
\text { strategy for buffering risks. } \\
\text { Livelihood strategies are institutionalized } \\
\text { in society and are examples of the } \\
\text { capacity to build resilience. In particular } \\
\text { social networks spanning places have } \\
\text { long historical continuities. } \\
\text { Strategies for reducing vulnerability in the } \\
\text { short term can inhibit the capacity to build } \\
\text { resilience in the long term. }\end{array}$ \\
\hline
\end{tabular}




\begin{tabular}{|c|c|c|c|c|c|c|c|c|c|}
\hline $\begin{array}{l}\text { Gallego } \\
\text { and } \\
\text { Mendola } \\
2013\end{array}$ & $\begin{array}{l}\text { Investigate how labor } \\
\text { migration in poor } \\
\text { developing settings } \\
\text { impacts social support } \\
\text { networks and cooper- } \\
\text { ative arrangements in } \\
\text { migrant-sending } \\
\text { communities in South } \\
\text { Mozambique. }\end{array}$ & $\begin{array}{l}\text { Implicit reference to } \\
\text { resilience: } \\
\text { Social networks and } \\
\text { migration are crucial } \\
\text { household strategies } \\
\text { for mobilizing a range } \\
\text { of economic re- } \\
\text { sources. Mobility } \\
\text { provides both the } \\
\text { households and the } \\
\text { local network with } \\
\text { potential access to } \\
\text { uncorrelated income } \\
\text { sources. }\end{array}$ & $\begin{array}{l}\text { Dependent: } \\
\text { Influence of migration } \\
\text { (remittances) on } \\
\text { social networks in the } \\
\text { origin of migration. }\end{array}$ & $\begin{array}{l}\text { Social capital: } \\
\text { Social networks as a } \\
\text { key source of infor- } \\
\text { mation and resources, } \\
\text { ultimately influencing } \\
\text { economic perfor- } \\
\text { mance. }\end{array}$ & $\begin{array}{l}\text { Descriptive: } \\
\text { Household survey in } \\
42 \text { communities in } \\
\text { four rural districts. } \\
\text { Econometric modeling } \\
\text { / analysis. }\end{array}$ & $\begin{array}{l}\text { Social relation: infor- } \\
\text { mal mutual support, } \\
\text { advice seeking from } \\
\text { relevant persons, } \\
\text { formal group mem- } \\
\text { bership. } \\
\text { Actors: households in } \\
\text { the community, } \\
\text { migrating household } \\
\text { members. } \\
\text { Scale: local / commu- } \\
\text { nity + linkages to } \\
\text { migrants. }\end{array}$ & $\begin{array}{l}\text { Individual: house- } \\
\text { holds. }\end{array}$ & $\begin{array}{l}\text { Actor: socioeconomic } \\
\text { / demographic data, } \\
\text { migration, remittanc- } \\
\text { es, perception of / } \\
\text { reason for community } \\
\text { participation. } \\
\text { Context: migration, } \\
\text { community level } \\
\text { characteristics. }\end{array}$ & $\begin{array}{l}\text { Households with successful migrants (i.e. } \\
\text { those receiving remittances or return } \\
\text { migration) engage more in community- } \\
\text { based social networks. } \\
\text { Income risks and participation constraints } \\
\text { may limit both access to and effective- } \\
\text { ness of social networks. } \\
\text { Thus higher income stability through } \\
\text { remittances or strong family migration } \\
\text { ties may decrease participation costs and } \\
\text { increase household commitment at the } \\
\text { community level. }\end{array}$ \\
\hline $\begin{array}{l}\text { Goulden } \\
\text { et al. } 2013\end{array}$ & $\begin{array}{l}\text { Examine the role of } \\
\text { social capital and } \\
\text { livelihood diversifica- } \\
\text { tion strategies for } \\
\text { adaptation to climate } \\
\text { variability.in dynamic } \\
\text { lakeshore social- } \\
\text { ecological systems in } \\
\text { Uganda }\end{array}$ & $\begin{array}{l}\text { Explicit reference to } \\
\text { resilience: } \\
\text { Social networks as } \\
\text { livelihood strategy } \\
\text { supporting adaptation } \\
\text { to climate variability } \\
\text { and promoting resili- } \\
\text { ence throughout the } \\
\text { adaptive cycle of the } \\
\text { coupled social- } \\
\text { ecological system. }\end{array}$ & $\begin{array}{l}\text { Independent: } \\
\text { Influence of social } \\
\text { networks on the } \\
\text { resilience of social- } \\
\text { ecological systems }\end{array}$ & $\begin{array}{l}\text { Social capital: } \\
\text { Social networks as } \\
\text { relations between } \\
\text { people that facilitate } \\
\text { productive activities. }\end{array}$ & $\begin{array}{l}\text { Descriptive: } \\
\text { Household survey, } \\
\text { focus group discus- } \\
\text { sions, and key in- } \\
\text { formant interviews in } \\
\text { two villages. } \\
\text { Regression analysis. }\end{array}$ & $\begin{array}{l}\text { Social relation: advice } \\
\text { seeking regarding } \\
\text { climate events, group } \\
\text { participation. } \\
\text { Actors: households in } \\
\text { the village and exter- } \\
\text { nal actors (organiza- } \\
\text { tions and institutions). } \\
\text { Scale: local / village + } \\
\text { linkages to external } \\
\text { actors. } \\
\text { Temporal scale: } \\
\text { 1950s to mid-2000s. }\end{array}$ & $\begin{array}{l}\text { Individual: house- } \\
\text { holds. }\end{array}$ & $\begin{array}{l}\text { Tie: type and strength } \\
\text { of ties (bonding, } \\
\text { bridging, linking). }\end{array}$ & $\begin{array}{l}\text { Households adapt to climate variability by } \\
\text { concurrent, spatial and temporal diversi- } \\
\text { fication of livelihoods, and by drawing on } \\
\text { social capital. However, these sources of } \\
\text { resilience are not sufficient in all circum- } \\
\text { stances. } \\
\text { The availability of adaptation options } \\
\text { varies according to the different stages in } \\
\text { the adaptive cycle of the social-ecological } \\
\text { system. } \\
\text { Bridging and linking social capital are } \\
\text { important for collective action and state } \\
\text { responses. Policies should promote } \\
\text { strong social capital within and between } \\
\text { social groups. }\end{array}$ \\
\hline $\begin{array}{l}\text { Islam and } \\
\text { Walkerden } \\
2014\end{array}$ & $\begin{array}{l}\text { Investigate the role of } \\
\text { bonding and bridging } \\
\text { relationships for } \\
\text { community resilience } \\
\text { to climate events in } \\
\text { coastal villages in } \\
\text { Bangladesh. }\end{array}$ & $\begin{array}{l}\text { Explicit reference to } \\
\text { resilience: } \\
\text { Social networks of } \\
\text { bonding and bridging } \\
\text { ties play a central role } \\
\text { in household resili- } \\
\text { ence and disaster } \\
\text { recovery. }\end{array}$ & $\begin{array}{l}\text { Independent: } \\
\text { Influence of social } \\
\text { networks on house- } \\
\text { hold resilience to } \\
\text { climatic risks. }\end{array}$ & $\begin{array}{l}\text { Social capital: } \\
\text { Social networks } \\
\text { (bonding and bridging } \\
\text { ties) as element of } \\
\text { social capital facilitat- } \\
\text { ing coordination and } \\
\text { cooperation for } \\
\text { mutual benefit. }\end{array}$ & $\begin{array}{l}\text { Descriptive: } \\
\text { Focus groups, meet- } \\
\text { ings with NGOs and } \\
\text { key informants, and } \\
\text { household surveys in } \\
\text { two coastal villages. } \\
\text { Descriptive statistics. }\end{array}$ & $\begin{array}{l}\text { Social relation: sup- } \\
\text { port (emotional, food, } \\
\text { shelter, cash, labor, } \\
\text { etc.). } \\
\text { Actors: households in } \\
\text { the community, } \\
\text { external actors } \\
\text { (NGOs). } \\
\text { Scale: local / commu- } \\
\text { nity + linkages to } \\
\text { external actors. } \\
\text { Temporal scale: } \\
\text { Weeks / months after } \\
\text { the event. }\end{array}$ & $\begin{array}{l}\text { Individual: house- } \\
\text { holds. }\end{array}$ & $\begin{array}{l}\text { Actor: socio-economic } \\
\text { / demographic data, } \\
\text { household assets. } \\
\\
\text { Tie: bonding ties } \\
\text { (household members } \\
+ \text { in-law households), } \\
\text { bridging ties (neigh- } \\
\text { bors and close } \\
\text { friends). }\end{array}$ & $\begin{array}{l}\text { Effected households draw heavily on } \\
\text { their bonding and bridging relationships } \\
\text { to face the immediate crisis. } \\
\text { Bridging ties (neighbors and friends) } \\
\text { break down after some time due to } \\
\text { conflict and resource constraints. For } \\
\text { longer-term recovery support through } \\
\text { linking social networks is needed. } \\
\text { Distribution of support is not equal: } \\
\text { NGOs favor their borrowers and local } \\
\text { governments favor members of their } \\
\text { political party. }\end{array}$ \\
\hline
\end{tabular}




\begin{tabular}{|c|c|c|c|c|c|c|c|c|c|}
\hline $\begin{array}{l}\text { Islam and } \\
\text { Walkerden } \\
2015\end{array}$ & $\begin{array}{l}\text { Examine how social } \\
\text { capital promotes } \\
\text { household disaster } \\
\text { recovery in coastal } \\
\text { villages in Bangla- } \\
\text { desh, in particular } \\
\text { linking social net- } \\
\text { works with NGOs. }\end{array}$ & $\begin{array}{l}\text { Explicit reference to } \\
\text { resilience: } \\
\text { Linking social net- } \\
\text { works - the links } \\
\text { between households } \\
\text { and external organi- } \\
\text { zations - form an } \\
\text { important part of } \\
\text { disaster resilience } \\
\text { and recovery. }\end{array}$ & $\begin{array}{l}\text { Independent: } \\
\text { Influence of social } \\
\text { networks on house- } \\
\text { hold resilience to } \\
\text { climatic risks. }\end{array}$ & $\begin{array}{l}\text { Social capital: } \\
\text { Social networks as an } \\
\text { aspect of social } \\
\text { capital, facilitating } \\
\text { coordination and } \\
\text { cooperation for } \\
\text { mutual benefit. }\end{array}$ & $\begin{array}{l}\text { Descriptive: } \\
\text { Focus groups, meet- } \\
\text { ings with NGOs and } \\
\text { key informants, and } \\
\text { household surveys in } \\
\text { two coastal villages. } \\
\text { Descriptive statistics. }\end{array}$ & $\begin{array}{l}\text { Social relation: links } \\
\text { to formal organiza- } \\
\text { tions, advice seeking, } \\
\text { material and financial } \\
\text { relief, livelihood } \\
\text { assistance. } \\
\text { Actors: households in } \\
\text { the community, } \\
\text { external actors } \\
\text { (NGOs). } \\
\text { Scale: local / commu- } \\
\text { nity + linkages to } \\
\text { external actors. }\end{array}$ & $\begin{array}{l}\text { Individual: house- } \\
\text { holds. }\end{array}$ & $\begin{array}{l}\text { Actor: socio-economic } \\
\text { / demographic data, } \\
\text { household assets. } \\
\text { Tie: linking ties to } \\
\text { organizations. }\end{array}$ & $\begin{array}{l}\text { Linking ties to NGOs provide support but } \\
\text { at the same time catalyze relief depend- } \\
\text { ency, because they focus on relief rather } \\
\text { than preparedness. }\end{array}$ \\
\hline $\begin{array}{l}\text { Kadigi et al. } \\
2007\end{array}$ & $\begin{array}{l}\text { Assess the spatial } \\
\text { dynamics and deter- } \\
\text { minants of livelihood } \\
\text { capital, vulnerability, } \\
\text { and coping strategies } \\
\text { for poor agrarian } \\
\text { households in Tanza- } \\
\text { nia, including the role } \\
\text { of social networks. }\end{array}$ & $\begin{array}{l}\text { Implicit reference to } \\
\text { resilience: } \\
\text { Social capital in form } \\
\text { of social networks of } \\
\text { trust and reciprocity } \\
\text { provides opportunities } \\
\text { for poor households } \\
\text { to cope with water } \\
\text { scarcity. }\end{array}$ & $\begin{array}{l}\text { Independent: } \\
\text { Influence of social } \\
\text { networks on the ability } \\
\text { of households to } \\
\text { pursue different } \\
\text { livelihood activities. }\end{array}$ & $\begin{array}{l}\text { Social capital: } \\
\text { Social networks as } \\
\text { aspect of social } \\
\text { capital: Networks } \\
\text { provide an informal } \\
\text { framework for infor- } \\
\text { mation sharing and } \\
\text { collective decision- } \\
\text { making and have } \\
\text { direct impact on other } \\
\text { types of capital. }\end{array}$ & $\begin{array}{l}\text { Metaphorical: } \\
\text { Household survey in } \\
\text { different sample } \\
\text { villages in the upper } \\
\text { and lower catchment. } \\
\text { Descriptive statistics. }\end{array}$ & $\begin{array}{l}\text { Social relation: infor- } \\
\text { mation sharing and } \\
\text { collective decision } \\
\text { making, labor sharing. } \\
\text { Actors: households. } \\
\text { Scale: (not specified) }\end{array}$ & $\begin{array}{l}\text { Individual: house- } \\
\text { holds. }\end{array}$ & $\begin{array}{l}\text { Context: climate } \\
\text { related shocks, } \\
\text { market / income } \\
\text { opportunities, access } \\
\text { to resources and } \\
\text { institutions. }\end{array}$ & $\begin{array}{l}\text { Collective labor arrangements, traditional } \\
\text { ceremonies, and informal group mem- } \\
\text { bership crosscut social strata and result } \\
\text { in higher levels of social capital for poor } \\
\text { households. } \\
\text { Nevertheless, households critically } \\
\text { depend on existing institutional arrange- } \\
\text { ments and mechanisms. }\end{array}$ \\
\hline $\begin{array}{l}\text { Katikiro } \\
\text { et al. } 2015\end{array}$ & $\begin{array}{l}\text { Describe how per- } \\
\text { ceived changes in a } \\
\text { fishery system such } \\
\text { as declining fish } \\
\text { stocks, market fail- } \\
\text { ures, and the loss of } \\
\text { important species } \\
\text { may strengthen or } \\
\text { weaken sociocultural } \\
\text { patterns in a fishing } \\
\text { community in Tanza- } \\
\text { nia. }\end{array}$ & $\begin{array}{l}\text { Implicit reference to } \\
\text { resilience: } \\
\text { Traditional networks } \\
\text { (based on kinship and } \\
\text { friendship) provide } \\
\text { opportunities for } \\
\text { mutual help, solidari- } \\
\text { ty, and social ex- } \\
\text { change. Hence, social } \\
\text { networks constitute a } \\
\text { critical safety net for } \\
\text { poor households. }\end{array}$ & $\begin{array}{l}\text { Dependent: } \\
\text { Impact of ecological } \\
\text { changes, market } \\
\text { changes, and in- } \\
\text { migration on patterns } \\
\text { of social exchange. }\end{array}$ & $\begin{array}{l}\text { Pipe: } \\
\text { Social networks a } \\
\text { means to access } \\
\text { resources and sup- } \\
\text { port. }\end{array}$ & $\begin{array}{l}\text { Metaphorical: } \\
\text { Semi-structured } \\
\text { interviews, focus } \\
\text { group discussions, } \\
\text { and life-history inter- } \\
\text { views in five coastal } \\
\text { villages. } \\
\text { Descriptive statistics. }\end{array}$ & $\begin{array}{l}\text { Social relation: mutual } \\
\text { support. } \\
\text { Actors: households in } \\
\text { the community. } \\
\text { Scale: local / village. }\end{array}$ & $\begin{array}{l}\text { Network: mutual } \\
\text { support networks. }\end{array}$ & $\begin{array}{l}\text { Tie: bonding ties } \\
\text { (based on kinship / } \\
\text { friendship). } \\
\text { Context: decline of } \\
\text { resources, market } \\
\text { integration, in- } \\
\text { migration. }\end{array}$ & $\begin{array}{l}\text { Informal social relations have become } \\
\text { loose and changeable due to perceived } \\
\text { ecological changes and the influx of } \\
\text { people without a fishing culture back- } \\
\text { ground. } \\
\text { This has led to an erosion of mutual help, } \\
\text { solidarity, and social exchange. However, } \\
\text { few primary bonds such as family and } \\
\text { clan networks have managed to survive } \\
\text { and even flourish within new situations. }\end{array}$ \\
\hline $\begin{array}{l}\text { Lyle and } \\
\text { Smith } 2014\end{array}$ & $\begin{array}{l}\text { Explore the linkages } \\
\text { between participation } \\
\text { in community collec- } \\
\text { tive activities and } \\
\text { access to adaptive } \\
\text { support networks in a } \\
\text { Peruvian highland } \\
\text { community. }\end{array}$ & $\begin{array}{l}\text { Implicit reference to } \\
\text { resilience: } \\
\text { Adaptive support } \\
\text { networks play a } \\
\text { prominent role in } \\
\text { alleviating social and } \\
\text { environmental stress- } \\
\text { ors. One reason for } \\
\text { collective benefits } \\
\text { from social networks } \\
\text { is that those who }\end{array}$ & $\begin{array}{l}\text { Dependent: } \\
\text { Influence of communi- } \\
\text { ty participation on } \\
\text { access to social } \\
\text { support networks. }\end{array}$ & $\begin{array}{l}\text { Social capital : } \\
\text { Participation in com- } \\
\text { munity activities as an } \\
\text { investment in social } \\
\text { networks facilitating } \\
\text { access to support and } \\
\text { resources. }\end{array}$ & $\begin{array}{l}\text { Structurally explicit: } \\
\text { Observation, archival } \\
\text { data, and household } \\
\text { interviews in an } \\
\text { Andean village. } \\
\text { SNA: total network. } \\
\text { Regression analysis. }\end{array}$ & $\begin{array}{l}\text { Social relation: agri- } \\
\text { cultural support (e.g. } \\
\text { watching herds, } \\
\text { providing advice on } \\
\text { animal husbandry). } \\
\text { Actors: households in } \\
\text { the village. } \\
\text { Scale: local / village. }\end{array}$ & $\begin{array}{l}\text { Network: village } \\
\text { support network. } \\
\text { Individual: house- } \\
\text { holds. }\end{array}$ & $\begin{array}{l}\text { Actor: household } \\
\text { health and composi- } \\
\text { tion, herd size, partic- } \\
\text { ipation in community } \\
\text { activities. } \\
\text { Tie: reciprocity. } \\
\text { Structure: degree } \\
\text { centrality. } \\
\text { Context: geographic }\end{array}$ & $\begin{array}{l}\text { Participation in collective action can } \\
\text { convey information about qualities of } \\
\text { fellow community members that are not } \\
\text { easily observable otherwise. } \\
\text { Cooperative households have better } \\
\text { reputations and have larger support } \\
\text { networks (and better household health). } \\
\text { As well, mean distance from other } \\
\text { households and per capita herd size are } \\
\text { significant predictors of network size. }\end{array}$ \\
\hline
\end{tabular}




\begin{tabular}{|c|c|c|c|c|c|c|c|c|c|}
\hline & & \begin{tabular}{|l|} 
contribute more \\
receive reputational \\
benefits, whereas \\
those who contribute \\
less incur reputational \\
costs.
\end{tabular} & & & & & & location. & \\
\hline $\begin{array}{l}\text { Nygren and } \\
\text { Myatt- } \\
\text { Hirvonen. } \\
2009\end{array}$ & $\begin{array}{l}\text { Analyze the diverse } \\
\text { ways in which peas- } \\
\text { ant households in } \\
\text { Honduras struggle to } \\
\text { earn their living and } \\
\text { cope with distress } \\
\text { amid globalization. }\end{array}$ & $\begin{array}{l}\text { Implicit reference to } \\
\text { resilience: } \\
\text { Social networks play } \\
\text { an ambiguous role in } \\
\text { shaping the opportu- } \\
\text { nities and constraints } \\
\text { of poor households to } \\
\text { cope with poverty. }\end{array}$ & $\begin{array}{l}\text { Dependent: } \\
\text { Factors influencing } \\
\text { the viability and } \\
\text { reproduction of social } \\
\text { networks. }\end{array}$ & $\begin{array}{l}\text { Social capital: } \\
\text { Social networks } \\
\text { providing access to } \\
\text { resources for coping } \\
\text { with distress. }\end{array}$ & \begin{tabular}{|l|} 
Descriptive: \\
Observation, partici- \\
pation, ethnographic \\
interviews, and semi- \\
structured households \\
interviews in all seven \\
villages of the region.
\end{tabular} & $\begin{array}{l}\text { Social relation: labor } \\
\text { exchange, money } \\
\text { lending, remittances, } \\
\text { market connections. } \\
\text { Actors: households, } \\
\text { and external actors } \\
\text { (intermediaries, } \\
\text { politicians, and } \\
\text { NGOs). } \\
\text { Scale: local / village + } \\
\text { linkages to external } \\
\text { actors. }\end{array}$ & $\begin{array}{l}\text { Individual: house- } \\
\text { holds. }\end{array}$ & $\begin{array}{l}\text { Actor: household } \\
\text { assets, household } \\
\text { composition, life- } \\
\text { history. } \\
\text { Context: political- } \\
\text { economic processes } \\
\text { and institutional } \\
\text { mechanisms shaping } \\
\text { rural livelihoods. }\end{array}$ & $\begin{array}{l}\text { Social networks are not a "capital" or } \\
\text { "asset" that poor always can draw from. } \\
\text { Rather networks are based on dynamic } \\
\text { and negotiated transactions that cannot } \\
\text { be mechanically stored or accumulated. } \\
\text { Networks are not necessarily available } \\
\text { and free of charge but are based upon } \\
\text { complex norms of reciprocity. } \\
\text { Cultivation of networks requires time, } \\
\text { effort and money which the poor peas- } \\
\text { ants lack. Instead, social networks tend } \\
\text { to reinforce the existing differences. }\end{array}$ \\
\hline $\begin{array}{l}\text { Orchard } \\
\text { et al. } 2015\end{array}$ & $\begin{array}{l}\text { Assess the associa- } \\
\text { tion between aquacul- } \\
\text { ture, livelihoods, and } \\
\text { social networks in } \\
\text { coastal communities } \\
\text { of North Vietnam. }\end{array}$ & $\begin{array}{l}\text { Explicit reference to } \\
\text { resilience: } \\
\text { Aspects of resilience } \\
\text { reside in the social } \\
\text { networks of natural } \\
\text { resource dependent } \\
\text { communities: They } \\
\text { facilitate access to } \\
\text { livelihood resources in } \\
\text { order to respond to } \\
\text { change and increase } \\
\text { the ability of commu- } \\
\text { nities to self-organize. }\end{array}$ & $\begin{array}{l}\text { Independent / } \\
\text { Dependent: } \\
\text { Influence of aquacul- } \\
\text { ture on social net- } \\
\text { works. } \\
\text { Influence of social } \\
\text { networks on the } \\
\text { resilience of local } \\
\text { communities. }\end{array}$ & $\begin{array}{l}\text { Social capital: } \\
\text { The structure and } \\
\text { function of social } \\
\text { networks is a crucial } \\
\text { aspect of social } \\
\text { capital enabling } \\
\text { people to act togeth- } \\
\text { er, and to pursue } \\
\text { shared benefits. }\end{array}$ & $\begin{array}{l}\text { Structurally explicit: } \\
\text { Household survey in } \\
\text { three coastal commu- } \\
\text { nities. } \\
\text { Livelihood diversity } \\
\text { index. } \\
\text { SNA: total network } \\
\text { (constructed from } \\
\text { ego-networks). }\end{array}$ & $\begin{array}{l}\text { Social relation: com- } \\
\text { munication about } \\
\text { mangrove system } \\
\text { related issues. } \\
\text { Actors: households, } \\
\text { external market } \\
\text { actors. } \\
\text { Scale: local / village + } \\
\text { linkages to external } \\
\text { actors. }\end{array}$ & $\begin{array}{l}\text { Network: mangrove } \\
\text { communication } \\
\text { network. } \\
\text { Individual: house- } \\
\text { holds. }\end{array}$ & $\begin{array}{l}\text { Actor: income, man- } \\
\text { grove dependency, } \\
\text { livelihood diversity. } \\
\text { Tie: bonding / bridging } \\
\text { ties. } \\
\text { Structure: centrality, } \\
\text { efficiency, effective } \\
\text { size, and constraint. } \\
\text { Context: market } \\
\text { integration. }\end{array}$ & $\begin{array}{l}\text { Economic transition alters mangrove } \\
\text { system governance through the increas- } \\
\text { ing influence of market mechanisms on } \\
\text { the structure of social networks. } \\
\text { Traditional dense social networks (bond- } \\
\text { ing capital) are replaced by larger and } \\
\text { less dense networks extending the } \\
\text { village level (bridging capital). } \\
\text { By reducing redundancy and connected- } \\
\text { ness market integration negatively } \\
\text { impacts the capacity of communities to } \\
\text { buffer the loss of ties and to self- } \\
\text { organize. This way, market integration } \\
\text { impacts community resilience. }\end{array}$ \\
\hline $\begin{array}{l}\text { Rindfuss } \\
\text { et al. } 2012\end{array}$ & $\begin{array}{l}\text { Examine the role of } \\
\text { family networks at } \\
\text { places of origin and } \\
\text { destination on mi- } \\
\text { grants' exchanges } \\
\text { with family members } \\
\text { in northeast Thailand. }\end{array}$ & $\begin{array}{l}\text { Implicit reference to } \\
\text { resilience: } \\
\text { Migrant remittances } \\
\text { are a crucial source } \\
\text { for livelihoods in less } \\
\text { developed countries. } \\
\text { Migrants are embed- } \\
\text { ded in a complex and } \\
\text { changing web of } \\
\text { social obligations } \\
\text { among close family / } \\
\text { kin and obligations in } \\
\text { the area of destina- } \\
\text { tion. }\end{array}$ & $\begin{array}{l}\text { Independent: } \\
\text { Influence of family } \\
\text { social networks on } \\
\text { migrants' remittance } \\
\text { behavior. }\end{array}$ & $\begin{array}{l}\text { Pipe: } \\
\text { Networks as a conduit } \\
\text { for exchanging and } \\
\text { facilitating flows of } \\
\text { support. }\end{array}$ & $\begin{array}{l}\text { Descriptive: } \\
\text { Complete village / } \\
\text { household census in } \\
\text { all villages of a rural } \\
\text { district. } \\
\text { Migrant interviews (in } \\
\text { destination areas). } \\
\text { Regression analysis. }\end{array}$ & $\begin{array}{l}\text { Social relation: trans- } \\
\text { fer of money, labor } \\
\text { and goods. } \\
\text { Actors: households in } \\
\text { the village and other } \\
\text { villages in the district, } \\
\text { migrants in destina- } \\
\text { tion areas. } \\
\text { Scale: regional / } \\
\text { district + linkages } \\
\text { between villages and } \\
\text { destination areas. } \\
\text { Temporal scale: } \\
\text { from } 1984 \text { to } 1994 .\end{array}$ & $\begin{array}{l}\text { Individual: house- } \\
\text { holds. }\end{array}$ & $\begin{array}{l}\text { Actors; age, gender, } \\
\text { education, occupa- } \\
\text { tion, migrant destina- } \\
\text { tion, household size. } \\
\text { Tie: ties to spouses, } \\
\text { children, and parents. }\end{array}$ & $\begin{array}{l}\text { Intra-family exchanges are influenced by } \\
\text { marital status of the migrant, the pres- } \\
\text { ence of children and parents in the } \\
\text { household of origin, and by having } \\
\text { siblings depart from it. The location of the } \\
\text { spouse is of relevance as well. }\end{array}$ \\
\hline
\end{tabular}




\begin{tabular}{|c|c|c|c|c|c|c|c|c|c|}
\hline $\begin{array}{l}\text { Rotberg } \\
2010\end{array}$ & $\begin{array}{l}\text { Investigate if and how } \\
\text { social networks and } \\
\text { key individuals con- } \\
\text { tribute to rural adapt- } \\
\text { ability to climate } \\
\text { related risks in Bang- } \\
\text { ladesh. }\end{array}$ & $\begin{array}{l}\text { Explicit reference to } \\
\text { resilience: } \\
\text { Key individuals in } \\
\text { formal and informal } \\
\text { social networks can } \\
\text { lead communities to } \\
\text { adaptive action and } \\
\text { can increase commu- } \\
\text { nities' resilience / } \\
\text { capacity to cope with } \\
\text { the impacts of climate } \\
\text { changes. }\end{array}$ & $\begin{array}{l}\text { Independent: } \\
\text { Influence of networks } \\
\text { and key individuals } \\
\text { within them on the } \\
\text { ability of households } \\
\text { and communities to } \\
\text { adapt. }\end{array}$ & $\begin{array}{l}\text { Social capital: } \\
\text { Social networks as a } \\
\text { source of coping and } \\
\text { adaptation to climate } \\
\text { related risks. }\end{array}$ & $\begin{array}{l}\text { Descriptive: } \\
\text { Focus group, inter- } \\
\text { views, and semi- } \\
\text { structured interviews } \\
\text { in a coastal village in } \\
\text { Bangladesh. }\end{array}$ & $\begin{array}{l}\text { Social relation: asking } \\
\text { for support in times of } \\
\text { flood, and general } \\
\text { assistance. } \\
\text { Actors: households, } \\
\text { external actors (or- } \\
\text { ganizations, NGOs). } \\
\text { Scale of interaction: } \\
\text { local + linkages to } \\
\text { external actors. } \\
\text { Temporal scale: } \\
\text { seasonal / annual. }\end{array}$ & $\begin{array}{l}\text { Individual: key indi- } \\
\text { viduals in the village } \\
\text { (brokers). }\end{array}$ & $\begin{array}{l}\text { Actor: education, } \\
\text { gender, age, em- } \\
\text { ployment, origin of } \\
\text { migration, trust and } \\
\text { respect (attributed by } \\
\text { the community). } \\
\text { Ties: tie strength } \\
\text { strong / weak ties and } \\
\text { type (internal / exter- } \\
\text { nal). }\end{array}$ & $\begin{array}{l}\text { Key individuals are important for social } \\
\text { network functioning. Key individuals that } \\
\text { are trusted and respected serve as } \\
\text { mobilizer and brokers and hence pro- } \\
\text { mote capacity to cope and to adapt. } \\
\text { Formal and informal linkages with NGOs } \\
\text { provide opportunities for income genera- } \\
\text { tion and the strengthening of networks. } \\
\text { Social capital is bolstered when embed- } \\
\text { ded in a network of reciprocal social } \\
\text { relations. Combination of strong and } \\
\text { weak ties leads to more resilient and } \\
\text { adaptable communities. }\end{array}$ \\
\hline $\begin{array}{l}\text { Scheffran } \\
\text { et al. } 2012\end{array}$ & \begin{tabular}{|l|} 
Investigate opportuni- \\
ties for framing migra- \\
tion as a contribution \\
to climate adaptation \\
by drawing on case \\
studies from the \\
Sahel region.
\end{tabular} & $\begin{array}{l}\text { Explicit reference to } \\
\text { resilience: } \\
\text { Communities and } \\
\text { migrants are active } \\
\text { agents who shape } \\
\text { their livelihoods under } \\
\text { changing conditions. } \\
\text { Migration creates } \\
\text { social capital that can } \\
\text { foster resilience in the } \\
\text { communities of origin. }\end{array}$ & $\begin{array}{l}\text { Independent: } \\
\text { Influence of social } \\
\text { networks on climate } \\
\text { change adaptation in } \\
\text { areas of destination. }\end{array}$ & $\begin{array}{l}\text { Social capital: } \\
\text { Networks promote } \\
\text { capabilities of mi- } \\
\text { grants and provide } \\
\text { access to resources } \\
\text { that enrich capitals } \\
\text { available at origin of } \\
\text { migration. }\end{array}$ & $\begin{array}{l}\text { Metaphorical: } \\
\text { Review of three case } \\
\text { studies from Western } \\
\text { Sahel region. }\end{array}$ & $\begin{array}{l}\text { Social relation: remit- } \\
\text { tances, innovation } \\
\text { and knowledge } \\
\text { transfer. } \\
\text { Actors: households } \\
\text { and migrants in areas } \\
\text { of destination. } \\
\text { Scale: local - interna- } \\
\text { tional migration } \\
\text { system. }\end{array}$ & $\begin{array}{l}\text { Network: migration } \\
\text { network. }\end{array}$ & (not specified) & $\begin{array}{l}\text { Migrant social networks can help building } \\
\text { social capital and fostering social resili- } \\
\text { ence in the communities of origin. Migra- } \\
\text { tion networks trigger innovations across } \\
\text { regions by transferring knowledge, } \\
\text { technology, remittances and other re- } \\
\text { sources. } \\
\text { Hence migration could increase the } \\
\text { flexibility, diversity, and creativity of } \\
\text { communities in addressing climate stress } \\
\text { and could open new pathways for co- } \\
\text { development. }\end{array}$ \\
\hline $\begin{array}{l}\text { Torkelsson } \\
2007\end{array}$ & $\begin{array}{l}\text { Analyze the role that } \\
\text { gender plays in the } \\
\text { distribution and } \\
\text { productivity of social } \\
\text { network ties in a rural } \\
\text { village in Ethiopia. }\end{array}$ & $\begin{array}{l}\text { Implicit reference to } \\
\text { resilience: } \\
\text { Social networks } \\
\text { provide access to } \\
\text { bonded and bridged } \\
\text { social resources and } \\
\text { therefore offer oppor- } \\
\text { tunities to confront } \\
\text { poverty and vulnera- } \\
\text { bility. }\end{array}$ & $\begin{array}{l}\text { Dependent: } \\
\text { Influence of gender } \\
\text { on the distribution and } \\
\text { productivity of net- } \\
\text { work ties. }\end{array}$ & $\begin{array}{l}\text { Social capital: } \\
\text { Social networks } \\
\text { provide access to } \\
\text { social resources that } \\
\text { can be exchanged } \\
\text { into other capitals. }\end{array}$ & \begin{tabular}{|l|} 
Descriptive: \\
Semi-structured \\
household interviews, \\
discussions, and \\
observations in a rural \\
village. \\
Document analysis.
\end{tabular} & $\begin{array}{l}\text { Social relation: partic- } \\
\text { ipation in formal / } \\
\text { informal institutions. } \\
\text { Actors: households in } \\
\text { the village, external } \\
\text { actors (formal organi- } \\
\text { zations). } \\
\text { Scale: local / village + } \\
\text { linkages to external } \\
\text { actors. }\end{array}$ & $\begin{array}{l}\text { Individual: house- } \\
\text { holds. }\end{array}$ & $\begin{array}{l}\text { Actor: gender. } \\
\text { Tie: bonding ties, } \\
\text { bridging ties (access } \\
\text { to formal institutions), } \\
\text { linking ties (contact to } \\
\text { external institutions, } \\
\text { e.g. NGOs). } \\
\text { Context: social norms, } \\
\text { social institutions. }\end{array}$ & $\begin{array}{l}\text { Men and women have different access to } \\
\text { social networks. It is shown that the } \\
\text { poorest and most vulnerable are those } \\
\text { excluded from social networks. } \\
\text { Networks of women revolve around } \\
\text { bonding ties at local level and lack } \\
\text { bridging ties to formal institutions (be- } \\
\text { cause of limited mobility and time con- } \\
\text { straints). }\end{array}$ \\
\hline $\begin{array}{l}\text { Zimmerer } \\
2014\end{array}$ & \begin{tabular}{|l} 
Examine agrobiodi- \\
versity in smallholder \\
cultural landscapes \\
with the goal of \\
offering new insights \\
into management and \\
policy options for the \\
resilience-based in- \\
situ conservation in \\
Bolivia.
\end{tabular} & $\begin{array}{l}\text { Explicit reference to } \\
\text { resilience: } \\
\text { Migration alters social } \\
\text { networks central to in- } \\
\text { situ conservation of } \\
\text { agro-diversity and } \\
\text { hence impacts social } \\
\text { ecological resilience. }\end{array}$ & $\begin{array}{l}\text { Dependent: } \\
\text { Influence of migration } \\
\text { on social networks. }\end{array}$ & $\begin{array}{l}\text { Pipe: } \\
\text { Livelihood networks } \\
\text { connecting various } \\
\text { groups through the } \\
\text { exchange of infor- } \\
\text { mation and influence. }\end{array}$ & $\begin{array}{l}\text { Metaphorical: } \\
\text { Survey on land use } \\
\text { and livelihood activi- } \\
\text { ties (including migra- } \\
\text { tion and social net- } \\
\text { works) in a highland } \\
\text { region. }\end{array}$ & $\begin{array}{l}\text { Social relation: kin- } \\
\text { ship, social relations } \\
\text { between livelihood } \\
\text { groups (not specified). } \\
\text { Actors: livelihood } \\
\text { groups. } \\
\text { Scale: (not specified) }\end{array}$ & (not specified) & Context: migration. & $\begin{array}{l}\text { Social networks of migration related } \\
\text { livelihood groups are powerfully shaped } \\
\text { through international and national migra- } \\
\text { tion, while at the same time supporting } \\
\text { agrobiodiversity use and in-situ conser- } \\
\text { vation. }\end{array}$ \\
\hline
\end{tabular}

